\title{
Mixed natural arylolefin-quinoline platinum(II) complexes: synthesis, structural characterization and in vitro cytotoxicity studies
}

\section{Nguyen Thi Thanh Chi, Pham Van Thong, Truong Thi Cam Mai and Luc Van Meervelt}

Acta Cryst. (2018). C74, 1732-1743

\section{-1U IUCr Journals CRYSTALLOGRAPHY JOURNALS ONLINE \\ Copyright (C) International Union of Crystallography \\ Author(s) of this paper may load this reprint on their own web site or institutional repository provided that this cover page is retained. Republication of this article or its storage in electronic databases other than as specified above is not permitted without prior permission in writing from the IUCr. \\ For further information see http://journals.iucr.org/services/authorrights.html}




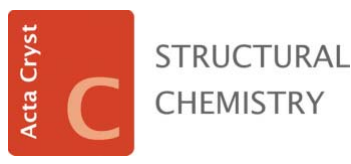

ISSN 2053-2296

Received 8 October 2018

Accepted 11 November 2018

Edited by N. Lugan, Laboratoire de Chimie de Coordination du CNRS, Toulouse, France

Keywords: platinum(II) complexes; crystal structure; anticancer activity; eugenol derivatives; quinoline.

CCDC references: 1878366; 1878365; $1878364 ; 1878363$

Supporting information: this article has supporting information at journals.iucr.org/C

\section{Mixed natural arylolefin-quinoline platinum(II) complexes: synthesis, structural characterization and in vitro cytotoxicity studies}

\author{
Nguyen Thi Thanh Chi, ${ }^{a *}$ Truong Thi Cam Mai ${ }^{\mathrm{b}}$ and Luc Van Meervelt ${ }^{\mathrm{c} *}$

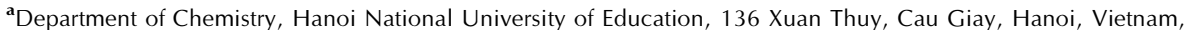 \\ ${ }^{\mathbf{b}}$ Department of Chemistry, Quy Nhon University, 170 An Duong Vuong, Quy Nhon, Vietnam, and ${ }^{\mathbf{c}}$ Department of \\ Chemistry, KU Leuven, Biomolecular Architecture, Celestijnenlaan 200F, Leuven (Heverlee), B-3001, Belgium. \\ *Correspondence e-mail: chintt@hnue.edu.vn, luc.vanmeervelt@kuleuven.be
}

Five new platinum(II) complexes bearing a eugenol and a quinoline derivative, namely [ $\eta^{2}-4$-allyl-2-methoxy-1-(propoxycarbonylmethoxy)benzene]-trans-dichlorido(quinoline- $\kappa N$ )platinum(II), $\left[\mathrm{PtCl}_{2}\left(\mathrm{C}_{15} \mathrm{H}_{20} \mathrm{O}_{4}\right)\left(\mathrm{C}_{9} \mathrm{H}_{7} \mathrm{~N}\right)\right],(2),\left\{\eta^{2}\right.$-4-allyl-2methoxy-1-[(propan-2-yloxy)carbonylmethoxy]benzene)-trans-dichlorido(quinoline- $\kappa N)$ platinum(II), $\left[\mathrm{PtCl}_{2}\left(\mathrm{C}_{15} \mathrm{H}_{19} \mathrm{O}_{4}\right)\left(\mathrm{C}_{9} \mathrm{H}_{7} \mathrm{~N}\right)\right],(3),\left[\eta^{2}\right.$-4-allyl-2-methoxy-1(propoxycarbonylmethoxy)benzene]chlorido(quinolin-8-olato- $\kappa^{2} N, O$ )platinum(II), $\left[\mathrm{Pt}\left(\mathrm{C}_{9} \mathrm{H}_{6} \mathrm{NO}\right) \mathrm{Cl}\left(\mathrm{C}_{15} \mathrm{H}_{20} \mathrm{O}_{4}\right)\right],(4),\left\{\eta^{2}\right.$-4-allyl-2-methoxy-1-[(propan-2-yloxy)carbonylmethoxy] benzene) chlorido(quinolin-8-olato- $\kappa^{2} N, O$ ) platinum(II), $\left[\mathrm{Pt}\left(\mathrm{C}_{9} \mathrm{H}_{6}\right.\right.$ $\left.\mathrm{NO}) \mathrm{Cl}\left(\mathrm{C}_{15} \mathrm{H}_{20} \mathrm{O}_{4}\right)\right]$, (5), and [ $\eta^{2}$-4-allyl-2-methoxy-1-(propoxycarbonylmethoxy)benzene]chlorido(quinolin-2-carboxylato- $\left.\kappa^{2} N, O\right)$ platinum(II), $\left[\mathrm{Pt}\left(\mathrm{C}_{10} \mathrm{H}_{6} \mathrm{NO}_{2}\right.\right.$ )$\left.\mathrm{Cl}\left(\mathrm{C}_{15} \mathrm{H}_{20} \mathrm{O}_{4}\right)\right]$, (6), have been synthesized and fully characterized spectroscopically. A single-crystal X-ray diffraction study was carried out for complexes (2) and (4)-(6). PrEug [or 4-allyl-2-methoxy-1-(propoxycarbonylmethoxy)benzene] in (2), (4) and (6), and ${ }^{\mathrm{i}}$ PrEug (the propan-2-yloxy analogue of PrEug) in (3) and (5) coordinate with $\mathrm{Pt}^{\mathrm{II}}$ at the ethylenic double bond of the allyl group. In (2)-(6), the donor $\mathrm{N}$ atom of the amine group occupies a trans position with respect to the double bond. A comparison of the $\mathrm{IC}_{50}$ values of 0.38-29.23 $\mu M$ for (2)-(6) with cisplatin, as well as other platinum(II) complexes, indicates an excellent in vitro cytotoxicity against the KB, LU, Hep-G2 and MCF-7 cancer cell lines, with the highest cytotoxic effect $\left(\mathrm{IC}_{50}=0.38-1.99 \mu M\right)$ being for complexes (4) and (5) bearing a quinolin-8-olate ligand.

\section{Introduction}

Although metal-containing drugs form only a small portion of the approved clinical drugs, platinum-based drugs, such as cisplatin, carboplatin and oxaliplatin, are still essential anticancer agents in cancer chemotherapy (Johnstone et al., 2014). Nevertheless, the unwanted side effects and the evolution of drug resistance during therapy of these drugs has been stimulating chemists to develop less toxic, more effective and target-specific metal-based anticancer drugs (Luo et al., 2014). Therefore, numerous platinum(II) complexes bearing natural bioactive ligands, such as safrole (Da et al., 2015), caffeine (Pneumatikakis, 1984; Shahabadi \& Moeini, 2015), derivatives of caffeine (Romerosa et al., 2004; Zhang et al., 2015), oleanoic acid (Fang et al., 2016), propyl gallate (Massoni et al., 2017) and peptides (Johnstone et al., 2016), were synthesized and demonstrated antitumour activities.

Eugenol or 4-allyl-2-methoxyphenol [part (a) in Scheme 1] is a major constituent of a number of medicinal plants, such as clove (Syzygium aromaticum) and tulsi (Ocimum sanctum L.). 
Eugenol possesses various interesting activities, such as antiviral (Tragoolpua \& Jatisatienr, 2007), antibacterial (Gill \& Holley, 2004), antifungal (Chami et al., 2004), anti-inflammatory and anesthetic properties (Pramod et al., 2013). Thus, eugenol has been recognized as a potent pharmacological phytochemical and is applied in the fragrance and flavouring industries (Pramod et al., 2013). Recently, eugenol and its derivatives [Meug and EtEug; part (a) in Scheme 1] have been introduced into the coordination entity of platinum(II) in series of complexes bearing amines (Chi et al., 2017a,b; Da et $a l ., 2015)$. Most of these complexes bearing quinoline or a chelator derived from quinolin-8-ol exhibit significant inhibitory activities on the tested human cancer cells, especially on the $\mathrm{KB}$ and Hep-G2 cell lines, with $\mathrm{IC}_{50}=0.43-9.58 \mu \mathrm{M}$. However, crystal data for these complexes are very limited, some examples being the crystal structures of $[\mathrm{PtCl}(\mathrm{Cl}-$ QO)(Eug)] (Chi et al., 2017a) and [Pt(EtEug-1H)(Qui-COO)] (Da et al., 2015). Moreover, complexes bearing propyl eugenoxyacetate (PrEug) or isopropyl eugenoxyacetate ( ${ }^{\mathrm{i}} \mathrm{PrEug}$ ) [part (a) in Scheme 1] and amines have not been studied so far.

(a)

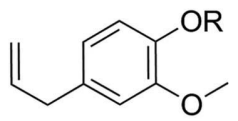

) $R$

$$
\text { Meug: } \mathrm{CH}_{3}
$$$$
\text { EtEug: } \mathrm{CH}_{2} \mathrm{COOCH}_{2} \mathrm{CH}_{3}
$$$$
\text { PrEug: } \left.\mathrm{CH}_{2} \mathrm{COOCH}_{2} \mathrm{CH}_{2} \mathrm{CH}_{3}\right\} \text { AlkEug }
$$<smiles>[R]c1ccc2cccc([R])c2n1</smiles>

(b)

Qui: $\mathrm{R}^{1}=\mathrm{R}^{2}=\mathrm{H}$

Qui-OH: $\mathrm{R}^{1}=\mathrm{H}, \mathrm{R}^{2}=\mathrm{OH}$

Qui-COOH: $\mathrm{R}^{1}=\mathrm{COOH}, \mathrm{R}^{2}=\mathrm{H}$

Scheme 1

In continuation of promising results on complexes containing derivatives of eugenol and quinoline, we report herein the synthesis and solution structure of five platinum(II) complexes bearing PrEug or ${ }^{\mathrm{i}}$ PrEug (AlkEug) and quinolines [part (b) in Scheme 1], as well as their in vitro cytotoxicity on the human cancer cell lines KB, Lu, Hep-G2 and MCF-7. In addition, the crystal structures of four of the five complexes have been investigated.

\section{Experimental}

Unless otherwise noted, all operations were performed without taking precautions to exclude air and moisture. All solvents and chemicals were used as received without further treatment if not noted otherwise. Amines were purchased from Sigma-Aldrich. Ocimum sanctum L. oil, extracted from tulsi plants and bearing about $70 \%$ eugenol, was purchased from the Essential Oils \& Aroma Joint Stock Company Vietnam Academy of Science and Technology.

Pt was analyzed according to the weight method (Ghelman et al., 1949) and C, H and N were analyzed on a LECO CHNS model 932 elemental analyzer. ESI-MS spectra were recorded on an 1100 LC-MSD-Trap-SL instrument. IR spectra were recorded on an IMPACK-410 NICOLET spectrometer in the range $400-4000 \mathrm{~cm}^{-1} .{ }^{1} \mathrm{H}$ NMR spectra were recorded on a Bruker AVANCE $500 \mathrm{MHz}$ at 298-300 K, and the chemical shifts $(\delta)$ were internally referenced by the residual solvent signals relative to tetramethylsilane (TMS). The ESI mass spectra (Fig. S1, S6, S10-S13, S17 and S18) and the ${ }^{1}$ H NMR spectra (Fig. S2-S5, S7-S9, S14-S16 and S19-S24) are given in the supporting information.

\subsection{Synthesis and crystallization}

2.1.1. Synthesis of AlkEug (PrEug and 'PrEug). A mixture of eugenoxyacetic acid [2.22 g, $10 \mathrm{mmol}$; prepared from Ocimum sanctum $L$. oil according to the synthetic protocol of Labarrios et al. (1999)] in propan-1-ol (30 ml) (for PrEug) or propan-2-ol (for ${ }^{\mathrm{i}} \mathrm{PrEug}$ ) and $\mathrm{H}_{2} \mathrm{SO}_{4}(0.5 \mathrm{ml})$ was refluxed for $20 \mathrm{~h}$. The reaction solution was concentrated to $\sim 5 \mathrm{ml}$ under reduced pressure and was then neutralized with an $\mathrm{Na}_{2} \mathrm{CO}_{3}$ solution. The resulting mixture was extracted and washed with warm water $(5 \times 5 \mathrm{ml})$ to afford the product as a yellowish oil after drying under vacuum for $2 \mathrm{~h}$.

PrEug: yield $1.11 \mathrm{~g}(42 \%)$. IR ( $\left.\mathrm{cm}^{-1}, v\right): 3060,2972,2840$ $(\mathrm{CH}) ; 1758(\mathrm{C}=\mathrm{O}) ; 1640,1590,1520(\mathrm{C}=\mathrm{C}) .{ }^{1} \mathrm{H}$ NMR $\left(500 \mathrm{~Hz}, \mathrm{CD}_{3} \mathrm{COCD}_{3}, \mathrm{ppm}\right): \delta 6.86\left(d,{ }^{3} J=8.0 \mathrm{~Hz}, 1 \mathrm{H}, \mathrm{Ar}-H\right)$, $6.84\left(d,{ }^{4} J=1.5 \mathrm{~Hz}, 1 \mathrm{H}\right.$, Ar- $\left.H\right), 6.68\left(d d,{ }^{3} J=8.0,{ }^{4} J=1.5 \mathrm{~Hz}\right.$, $1 \mathrm{H}, \operatorname{Ar}-H), 5.96\left(m, 1 \mathrm{H}, \mathrm{CH}=\mathrm{CH}_{2}\right), 5.07\left(d d,{ }^{3} J=15.0,{ }^{2} J=\right.$ $\left.1.5 \mathrm{~Hz}, 1 \mathrm{H}, \mathrm{CH}=\mathrm{CH}_{2}\right), 5.01\left(d d,{ }^{3} \mathrm{~J}=10.0,{ }^{2} \mathrm{~J}=1.5 \mathrm{~Hz}, 1 \mathrm{H}\right.$, $\left.\mathrm{CH}=\mathrm{CH}_{2}\right), 4.65\left(s, 2 \mathrm{H}, \mathrm{OCH}_{2}\right), 4.10\left(t,{ }^{3} \mathrm{~J}=7.0 \mathrm{~Hz}, 2 \mathrm{H}\right.$, $\left.\mathrm{CH}_{2} \mathrm{CH}_{2} \mathrm{CH}_{3}\right), 3.82\left(s, 3 \mathrm{H}, \mathrm{OCH}_{3}\right), 3.32\left(d,{ }^{3} \mathrm{~J}=7.0 \mathrm{~Hz}, 1 \mathrm{H}\right.$, $\left.\mathrm{CH}_{2}-\mathrm{CH}\right), 1.67\left(\mathrm{~m}, 2 \mathrm{H}, \mathrm{CH}_{2} \mathrm{CH}_{2} \mathrm{CH}_{3}\right), 0.91\left(t,{ }^{3} \mathrm{~J}=7.0 \mathrm{~Hz}, 3 \mathrm{H}\right.$, $\mathrm{CH}_{2} \mathrm{CH}_{2} \mathrm{CH}_{3}$ ).

${ }^{\mathrm{i}}$ PrEug: yield $1.19 \mathrm{~g}(45 \%)$. IR $\left(\mathrm{cm}^{-1}, v\right)$ : 3050, 2968, 2835 $(\mathrm{CH}) ; 1760(\mathrm{C}=\mathrm{O}) ; 1640,1593,1515(\mathrm{C}=\mathrm{C}) .{ }^{1} \mathrm{H}$ NMR $\left(500 \mathrm{~Hz}, \mathrm{CD}_{3} \mathrm{COCD}_{3}, \mathrm{ppm}\right): \delta$ 6.85-6.84 (ov, 2H, Ar-H), 6.69 $\left(d d,{ }^{3} J=8.0,{ }^{4} \mathrm{~J}=1.5 \mathrm{~Hz}, 1 \mathrm{H}, \mathrm{Ar}-H\right), 5.96\left(\mathrm{~m}, 1 \mathrm{H}, \mathrm{CH}=\mathrm{CH}_{2}\right)$, 5.09-5.00 (ov, 3H, $\left.\mathrm{CH}=\mathrm{CH}_{2}, \mathrm{OCH}\right), 4.61\left(s, 2 \mathrm{H}, \mathrm{OCH}_{2}\right), 3.81$ $\left(s, 3 \mathrm{H}, \mathrm{OCH}_{3}\right), 3.32\left(d,{ }^{3} \mathrm{~J}=7.0 \mathrm{~Hz}, 2 \mathrm{H}, \mathrm{CH}_{2}-\mathrm{CH}\right), 1.23\left[d,{ }^{3} \mathrm{~J}=\right.$ $\left.6.5 \mathrm{~Hz}, 6 \mathrm{H}, \mathrm{CH}\left(\mathrm{CH}_{3}\right)_{2}\right]$.

2.1.2. Synthesis of $\mathrm{K}\left[\mathrm{PtCl}_{3}\right.$ (PrEug)], (1a), and $\mathrm{K}\left[\mathrm{PtCl}_{3}-\right.$ ('PrEug)], (1b). PrEug [for (1a)] or ${ }^{\mathrm{i}} \mathrm{PrEug}$ [for (1b)] (2.90 g, $11.0 \mathrm{mmol})$ was mixed with Zeise's salt $\left\{\mathrm{K}\left[\mathrm{PtCl}_{3}\left(\mathrm{C}_{2} \mathrm{H}_{4}\right)\right] \cdot \mathrm{H}_{2} \mathrm{O}\right.$; $3.86 \mathrm{~g}, 10.0 \mathrm{mmol}\}$. The reaction mixture was stirred thoroughly for $1 \mathrm{~h}$ at ambient temperature until it began to transform into a viscous state and was then washed with diethyl ether $(3 \times 5 \mathrm{ml})$. The product was obtained as a yellow powder. The yield was $562 \mathrm{mg}(93 \%)$ for (1a) and $574 \mathrm{mg}$ (95\%) for (1b). The ESI-MS, IR and ${ }^{1} \mathrm{H}$ NMR spectra of (1a) and (1b) have been described by Chi et al. (2013) and Thong \& Chi (2014), respectively.

2.1.3. Synthesis of trans-[PtCl $2(\operatorname{PrEug})(\mathrm{Qui})],(2)$. A solution of quinoline $(130 \mu \mathrm{l}, 1.1 \mathrm{mmol})$ in ethanol $(5 \mathrm{ml})$ was 
added slowly with stirring at room temperature to a suspension of (1a) $(604 \mathrm{mg}, 1.0 \mathrm{mmol})$ in ethanol $(10 \mathrm{ml})$ for $1 \mathrm{~h}$. The reaction mixture was stirred for a further $2 \mathrm{~h}$ and then filtered through Celite to give a clear light-yellow solution. Slow evaporation of the solvent of the obtained solution under ambient conditions over a period of $8 \mathrm{~h}$ afforded yellow crystals, which were suitable for X-ray diffraction and other analyses. The yield was $592 \mathrm{mg}$ (90\%). Analysis calculated for $\mathrm{C}_{24} \mathrm{H}_{27} \mathrm{Cl}_{2} \mathrm{NO}_{4} \mathrm{Pt}$ : Pt 29.64, C 43.77, $\mathrm{H}$ 4.10, N 2.13; found: $\mathrm{Pt}$ 30.14, C 43.92, H 3.98, N 2.24\%. ESI-MS ( $\mathrm{m} / z$, intensity), -MS: 1023, 100\%, [2(M-Qui - HCl $)+\mathrm{Cl}]^{-} ; 567,55 \%,[M-$ Qui $+\mathrm{Cl}]^{-}$. IR $\left(\mathrm{cm}^{-1}, v\right): 3054,2961,2930(\mathrm{CH}) ; 1751(\mathrm{C}=\mathrm{O})$; 1590, 1511, $1460 \quad(\mathrm{C}=\mathrm{C}, \quad \mathrm{C}=\mathrm{N}) .{ }^{1} \mathrm{H} \quad \mathrm{NMR} \quad(500 \mathrm{~Hz}$, $\left.\mathrm{CD}_{3} \mathrm{COCD}_{3}, \mathrm{ppm}\right): \delta 9.03\left(d,{ }^{3} J=5.0 \mathrm{~Hz}, 1 \mathrm{H}, \mathrm{Ar}-H\right), 8.82(\mathrm{br}$, $1 \mathrm{H}, \operatorname{Ar}-H), 8.68\left(d,{ }^{3} J=8.0 \mathrm{~Hz}, 1 \mathrm{H}, \operatorname{Ar}-H\right), 8.15\left(d,{ }^{3} J=8.0 \mathrm{~Hz}\right.$, $1 \mathrm{H}, \operatorname{Ar}-H), 7.89\left(t,{ }^{3} J=8.0 \mathrm{~Hz}, 1 \mathrm{H}, \operatorname{Ar}-H\right), 7.82\left(d d,{ }^{3} J=5.0\right.$; $8.0 \mathrm{~Hz}, 1 \mathrm{H}, \mathrm{Ar}-H), 7.78\left(t,{ }^{3} J=8.0 \mathrm{~Hz}, 1 \mathrm{H}, \mathrm{Ar}-H\right), 7.29\left(d,{ }^{4} J=\right.$ $1.5 \mathrm{~Hz}, 1 \mathrm{H}, \mathrm{Ar}-H), 7.11\left(d d,{ }^{3} J=8.0,{ }^{4} J=1.5 \mathrm{~Hz}, 1 \mathrm{H}, \mathrm{Ar}-H\right)$, $7.03\left(d,{ }^{3} J=8.0 \mathrm{~Hz}, 1 \mathrm{H}, \operatorname{Ar}-H\right), 5.91\left(m,{ }^{2} J_{\mathrm{Pt}-\mathrm{H}}=70 \mathrm{~Hz}, 1 \mathrm{H}\right.$, $\left.\mathrm{CH}=\mathrm{CH}_{2}\right), 4.83\left(d d,{ }^{3} \mathrm{~J}=14.0,{ }^{2} \mathrm{~J}=1.5,{ }^{2} J_{\mathrm{Pt}-\mathrm{H}}=70 \mathrm{~Hz}, 1 \mathrm{H}\right.$, $\left.\mathrm{CH}=\mathrm{CH}_{2}\right), 4.80\left(s, 2 \mathrm{H}, \mathrm{OCH}_{2}\right), 4.72\left(d d,{ }^{3} \mathrm{~J}=8.0,{ }^{2} \mathrm{~J}=1.5\right.$, $\left.{ }^{2} J_{\mathrm{Pt}-\mathrm{H}}=70 \mathrm{~Hz}, 1 \mathrm{H}, \mathrm{CH}=\mathrm{CH}_{2}\right), 4.15\left(t,{ }^{3} \mathrm{~J}=7.0 \mathrm{~Hz}, 2 \mathrm{H}\right.$, $\left.\mathrm{CH}_{2} \mathrm{CH}_{2} \mathrm{CH}_{3}\right), 3.79\left(s, 3 \mathrm{H}, \mathrm{OCH}_{3}\right), 3.61\left(d d,{ }^{2} \mathrm{~J}=15,{ }^{3} \mathrm{~J}=\right.$ $\left.9.5 \mathrm{~Hz}, 1 \mathrm{H}, \mathrm{CH}_{2}-\mathrm{CH}\right), 3.31\left(\mathrm{dd},{ }^{2} \mathrm{~J}=15,{ }^{3} \mathrm{~J}=5.0 \mathrm{~Hz}, 1 \mathrm{H}, \mathrm{CH}_{2}-\right.$ $\mathrm{CH}), 1.67\left(m, 2 \mathrm{H}, \mathrm{CH}_{2} \mathrm{CH}_{2} \mathrm{CH}_{3}\right), 0.93\left(t,{ }^{3} \mathrm{~J}=7.0 \mathrm{~Hz}, 3 \mathrm{H}\right.$, $\mathrm{CH}_{2} \mathrm{CH}_{2} \mathrm{CH}_{3}$ ).

2.1.4. Synthesis of trans-[PtCl${ }_{2}$ ('PrEug)(Qui)], (3). Complex (3) was prepared starting from (1b) $(604 \mathrm{mg}, 1.0 \mathrm{mmol})$ and quinoline $(130 \mu \mathrm{l}, 1.1 \mathrm{mmol})$, according to the procedure for the preparation of (2). The yield was $599 \mathrm{mg}(91 \%)$ as small yellow crystals. Analysis calculated for $\mathrm{C}_{24} \mathrm{H}_{27} \mathrm{Cl}_{2} \mathrm{NO}_{4} \mathrm{Pt}$ : $\mathrm{Pt}$ 29.64, C 43.77, H 4.10, N 2.13; found: Pt 30.08, C 43.56, H 4.18, N 2.02\%. ESI-MS ( $\mathrm{m} / \mathrm{z}$, intensity), -MS: 1022, 100\%, [2( $M-$ Qui $-\mathrm{HCl})+\mathrm{Cl}]^{-} ; 528,30 \%,[M-\text { Qui }-\mathrm{HCl}+\mathrm{Cl}]^{-}$. IR $\left(\mathrm{cm}^{-1}\right)$ : 3054, 2951, $2930(\mathrm{CH}) ; 1751(\mathrm{C}=\mathrm{O}) ; 1590,1511,1460$ $(\mathrm{C}=\mathrm{C}, \mathrm{C}=\mathrm{N}) .{ }^{1} \mathrm{H}$ NMR $\left(500 \mathrm{~Hz}, \mathrm{CD}_{3} \mathrm{COCD}_{3}, \mathrm{ppm}\right): \delta 9.02$ $\left(d,{ }^{3} J=5.0 \mathrm{~Hz}, 1 \mathrm{H}, \mathrm{Ar}-H\right), 8.82(\mathrm{br}, 1 \mathrm{H}, \mathrm{Ar}-H), 8.68\left(d,{ }^{3} J=\right.$ $8.0 \mathrm{~Hz}, 1 \mathrm{H}, \mathrm{Ar}-H), 8.14\left(d,{ }^{3} J=8.0 \mathrm{~Hz}, 1 \mathrm{H}, \mathrm{Ar}-H\right), 7.89\left(t,{ }^{3} J=\right.$ $8.0 \mathrm{~Hz}, 1 \mathrm{H}, \mathrm{Ar}-H), 7.82\left(d d,{ }^{3} J=5.0 ; 8.0 \mathrm{~Hz}, 1 \mathrm{H}, \mathrm{Ar}-H\right), 7.77(t$, $\left.{ }^{3} J=8.0 \mathrm{~Hz}, 1 \mathrm{H}, \mathrm{Ar}-H\right), 7.28\left(d,{ }^{4} J=1.5 \mathrm{~Hz}, 1 \mathrm{H}\right.$, Ar- $\left.H\right), 7.11$ $\left(d d,{ }^{3} J=8.0,{ }^{4} J=1.5 \mathrm{~Hz}, 1 \mathrm{H}, \operatorname{Ar}-H\right), 7.01\left(d,{ }^{3} J=8.0 \mathrm{~Hz}, 1 \mathrm{H}\right.$, Ar- $H), 5.91\left(m,{ }^{2} J_{\mathrm{Pt}-\mathrm{H}}=70 \mathrm{~Hz}, 1 \mathrm{H}, \mathrm{CH}=\mathrm{CH}_{2}\right), 5.10(m, 1 \mathrm{H}$, $\mathrm{OCH}), 4.83\left(d d,{ }^{3} J=14,{ }^{2} J=1.5,{ }^{2} J_{\mathrm{Pt}-\mathrm{H}}=70 \mathrm{~Hz}, 1 \mathrm{H}\right.$, $\left.\mathrm{CH}=\mathrm{CH}_{2}\right), 4.74\left(s, 2 \mathrm{H}, \mathrm{OCH}_{2}\right), 4.72\left(d d,{ }^{3} \mathrm{~J}=8.5,{ }^{2} \mathrm{~J}=1.5\right.$, $\left.{ }^{2} J_{\mathrm{Pt}-\mathrm{H}}=70 \mathrm{~Hz}, 1 \mathrm{H}, \mathrm{CH}=\mathrm{CH}_{2}\right), 3.79\left(s, 3 \mathrm{H}, \mathrm{OCH}_{3}\right), 3.61(d d$, $\left.{ }^{2} J=15,{ }^{3} J=9.0 \mathrm{~Hz}, 1 \mathrm{H}, \mathrm{CH}_{2}-\mathrm{CH}\right), 3.31\left(d d,{ }^{2} \mathrm{~J}=15,{ }^{3} \mathrm{~J}=\right.$ $\left.5.0,{ }^{3} J_{\mathrm{Pt}-\mathrm{H}} 50 \mathrm{~Hz}, 1 \mathrm{H}, \mathrm{CH}_{2}-\mathrm{CH}\right), 1.26\left[d,{ }^{3} \mathrm{~J}=6.5 \mathrm{~Hz}, 6 \mathrm{H}\right.$, $\left.\mathrm{CH}\left(\mathrm{CH}_{3}\right)_{2}\right]$.

2.1.5. Synthesis of [PtCl(Qui-O)(PrEug)], (4). Complex (4) was prepared starting from (1a) $(604 \mathrm{mg}, 1.0 \mathrm{mmol})$ and quinolin-8-ol (145 mg, $1.0 \mathrm{mmol})$, according to the procedure for the preparation of (2). The yield was $587 \mathrm{mg}(92 \%)$ of orange-yellow crystals which were suitable for X-ray diffraction and other analyses. Analysis calculated for $\mathrm{C}_{24} \mathrm{H}_{26}{ }^{-}$ $\mathrm{ClNO}_{5}$ Pt: Pt 30.56, C 45.14, H 4.08, N 2.19; found: Pt 30.94, C 45.32, H 4.23, N 2.29\%. ESI-MS ( $m / z$, intensity), +MS: 640, $50 \%,[M+\mathrm{H}]^{+} ; 603,100 \%,[M-\mathrm{Cl}]^{+} ;-\mathrm{MS}: 637,45 \%,[M-$
$\mathrm{H}]^{-} ;$596, 100\%, $\left[M-\mathrm{C}_{3} \mathrm{H}_{7}\right]^{-} ; 409,25 \%,[M-\operatorname{PrEug}+\mathrm{Cl}]^{-}$. The data for the IR and ${ }^{1} \mathrm{H}$ NMR spectra of (4) have been described by Chi et al. (2014).

2.1.6. Synthesis of [PtCl(Qui-O)('PrEug)], (5). Complex (5) was prepared starting from (1b) $(604 \mathrm{mg}, 1.0 \mathrm{mmol})$ and quinolin-8-ol (145 mg, $1.0 \mathrm{mmol}$ ), according to the procedure for the preparation of (2). The yield was $574 \mathrm{mg}(90 \%)$ of orange-yellow crystals which were suitable for X-ray diffraction and other analyses. Analysis calculated (\%) for $\mathrm{C}_{24} \mathrm{H}_{26} \mathrm{ClNO}_{5} \mathrm{Pt}$ : Pt 30.56, C 45.14, $\mathrm{H}$ 4.08, N 2.19; found: $\mathrm{Pt}$ 30.69, C 45.01, H 4.19, N 2.26\%. ESI-MS ( $\mathrm{m} / \mathrm{z}$, intensity), +MS: 640, 35\%, $[M+\mathrm{H}]^{+} ; 603,100 \%,[M-\mathrm{Cl}]^{+} ; 561,30 \%,[M-$ $\mathrm{Cl}]^{+}$; -MS: 637, 100\%, $[M-\mathrm{H}]^{-} ; 596,15 \%,\left[M-\mathrm{C}_{3} \mathrm{H}_{7}\right]^{-} ; 409$, $75 \%,\left[M-{ }^{\mathrm{i}} \operatorname{PrEug}+\mathrm{Cl}\right]^{-}$. IR $\left(\mathrm{cm}^{-1}, v\right): 3075,2933,2850(\mathrm{CH})$; $1753(\mathrm{C}=\mathrm{O}) ; 1583,1500 ; 1462(\mathrm{C}=\mathrm{C}, \mathrm{C}=\mathrm{N}) .{ }^{1} \mathrm{H}$ NMR $\left(500 \mathrm{~Hz}, \mathrm{CD}_{3} \mathrm{COCD}_{3}, \mathrm{ppm}\right): \delta 9.07\left(d,{ }^{3} J=5.0,{ }^{3} J_{\mathrm{Pt}-\mathrm{H}}=34 \mathrm{~Hz}\right.$, $1 \mathrm{H}, \operatorname{Ar}-H), 8.76\left(d,{ }^{3} J=8.0 \mathrm{~Hz}, 1 \mathrm{H}, \operatorname{Ar}-H\right), 7.82\left(d d,{ }^{3} J=5.0\right.$, $8.0 \mathrm{~Hz}, 1 \mathrm{H}, \mathrm{Ar}-H), 7.51\left(t,{ }^{3} \mathrm{~J}=8.0 \mathrm{~Hz}, 1 \mathrm{H}, \mathrm{Ar}-H\right), 7.23\left(d,{ }^{3} \mathrm{~J}=\right.$ $8.0 \mathrm{~Hz}, 1 \mathrm{H}, \operatorname{Ar}-H), 7.15\left(d,{ }^{4} J=1.5 \mathrm{~Hz}, 1 \mathrm{H}, \operatorname{Ar}-H\right), 7.06\left(d,{ }^{3} J=\right.$ $8.0 \mathrm{~Hz}, 1 \mathrm{H}, \mathrm{Ar}-H), 6.92\left(d d,{ }^{3} J=8.0,{ }^{4} J=1.5 \mathrm{~Hz}, 1 \mathrm{H}, \mathrm{Ar}-H\right)$, $6.81\left(d,{ }^{3} J=8.0 \mathrm{~Hz}, 1 \mathrm{H}\right.$, Ar- $\left.H\right), 5.61\left(m,{ }^{2} J_{\mathrm{Pt}-\mathrm{H}}=70 \mathrm{~Hz}, 1 \mathrm{H}\right.$, $\left.\mathrm{CH}=\mathrm{CH}_{2}\right), 5.00(m, 1 \mathrm{H}, \mathrm{OCH}), 4.76\left(d,{ }^{3} \mathrm{~J}=14,{ }^{2} J_{\mathrm{Pt}-\mathrm{H}}=70 \mathrm{~Hz}\right.$, $\left.1 \mathrm{H}, \mathrm{CH}=\mathrm{CH}_{2}\right), 4.74\left(d,{ }^{3} \mathrm{~J}=9.0,{ }^{2} J_{\mathrm{Pt}-\mathrm{H}}=70 \mathrm{~Hz}, 1 \mathrm{H}\right.$, $\left.\mathrm{CH}=\mathrm{CH}_{2}\right), 4.57\left(s, 2 \mathrm{H}, \mathrm{OCH}_{2}\right), 3.60\left(d d,{ }^{2} \mathrm{~J}=15,{ }^{3} \mathrm{~J}=7.5 \mathrm{~Hz}\right.$, $\left.1 \mathrm{H}, \mathrm{CH}_{2}-\mathrm{CH}\right), 3.49\left(s, 3 \mathrm{H}, \mathrm{OCH}_{3}\right), 3.27\left(d d,{ }^{2} \mathrm{~J}=15,{ }^{3} \mathrm{~J}=\right.$ $\left.6.0,{ }^{3} J_{\mathrm{Pt}-\mathrm{H}}=50 \mathrm{~Hz}, 1 \mathrm{H}, \mathrm{CH}_{2}-\mathrm{CH}\right), 1.19\left[d,{ }^{3} \mathrm{~J}=6.0 \mathrm{~Hz}, 6 \mathrm{H}\right.$, $\left.\mathrm{CH}\left(\mathrm{CH}_{3}\right)_{2}\right]$.

2.1.7. Synthesis of $[\mathrm{PtCl}(\mathrm{Qui}-\mathrm{COO})(\mathrm{PrEug})],(6)$. Complex (6) was prepared starting from (1a) $(604 \mathrm{mg}, 1.0 \mathrm{mmol})$ with quinoline-2-carboxylic acid $(173 \mathrm{mg}, 1.0 \mathrm{mmol})$ in ethanol $(10 \mathrm{ml})$ at room temperature, according to the procedure for the preparation of 2 . The yield was $593 \mathrm{mg}$ (89\%) of small yellow crystals. Single crystals suitable for X-ray diffraction were obtained by slow evaporation within $10 \mathrm{~h}$ from a concentrated chloroform solution at ambient temperature. Analysis calculated (\%) for $\mathrm{C}_{25} \mathrm{H}_{26} \mathrm{ClNO}_{6} \mathrm{Pt}$ : $\mathrm{Pt} 29.28$, C 45.05, H 3.90, N 2.10; found: Pt 29.46, C 45.22, H 3.82, N 2.18. ESIMS $(\mathrm{m} / z$, intensity $),+\mathrm{MS}: 667,25 \%,[M+\mathrm{H}]^{+} ; 631,100 \%,[M-$ $\mathrm{Cl}]^{+}$; -MS: 702, 100\%, $[M+\mathrm{Cl}]^{-} ; 666,10 \%,[M-\mathrm{H}]^{-} ; 438$, $25 \%,[M-\operatorname{PrEug}+\mathrm{Cl}]^{-}$. IR $\left(\mathrm{cm}^{-1}, v\right): 3101,2950$ and 2936 $(\mathrm{CH}) ; 1751 ; 1674(\mathrm{C}=\mathrm{O}) ; 1597,1512$ and $1458(\mathrm{C}=\mathrm{C}, \mathrm{C}=\mathrm{N})$. ${ }^{1} \mathrm{H}$ NMR $\left(500 \mathrm{~Hz}, \mathrm{CDCl}_{3}, \mathrm{ppm}\right): \delta 9.58\left(d,{ }^{3} \mathrm{~J}=8.5 \mathrm{~Hz}, 1 \mathrm{H}\right.$, $\operatorname{Ar}-H), 8.68\left(d,{ }^{3} J=8.5 \mathrm{~Hz}, 1 \mathrm{H}, \operatorname{Ar}-H\right), 8.24\left(d,{ }^{3} J=8.5 \mathrm{~Hz}, 1 \mathrm{H}\right.$, $\operatorname{Ar}-H), 8.01\left(d,{ }^{3} J=8.5 \mathrm{~Hz}, 1 \mathrm{H}, \operatorname{Ar}-H\right), 7.94\left(t-d,{ }^{3} J=8.5,{ }^{4} J=\right.$ $1.5 \mathrm{~Hz}, 1 \mathrm{H}, \operatorname{Ar}-H), 7.80\left(t,{ }^{3} J=8.5 \mathrm{~Hz}, 1 \mathrm{H}, \operatorname{Ar}-H\right), 6.95(s, 1 \mathrm{H}$, $\operatorname{Ar}-H), 6.88\left(d,{ }^{3} J=8.0 \mathrm{~Hz}, 1 \mathrm{H}, \operatorname{Ar}-H\right), 6.78\left(d,{ }^{3} J=8.0 \mathrm{~Hz}, 1 \mathrm{H}\right.$, Ar- $H), 5.90\left(m,{ }^{2} J_{\mathrm{Pt}-\mathrm{H}}=70 \mathrm{~Hz}, 1 \mathrm{H}, \mathrm{CH}=\mathrm{CH}_{2}\right), 4.88-4.91(\mathrm{ov}$, $\left.2 \mathrm{H}, \mathrm{CH}=\mathrm{CH}_{2}\right), 4.64\left(s, 2 \mathrm{H}, \mathrm{OCH}_{2}\right), 4.13\left(t,{ }^{3} \mathrm{~J}=7.0 \mathrm{~Hz}, 2 \mathrm{H}\right.$, $\left.\mathrm{CH}_{2} \mathrm{CH}_{2} \mathrm{CH}_{3}\right), 3.83\left(s, 3 \mathrm{H}, \mathrm{OCH}_{3}\right), 3.57\left(b r, 1 \mathrm{H}, \mathrm{CH}_{2}-\mathrm{CH}\right)$, $3.22\left(b r, 1 \mathrm{H}, \mathrm{CH}_{2}-\mathrm{CH}\right), 1.64\left(m, 2 \mathrm{H}, \mathrm{CH}_{2} \mathrm{CH}_{2} \mathrm{CH}_{3}\right), 0.89(t$, $\left.{ }^{3} \mathrm{~J}=7.0 \mathrm{~Hz}, 3 \mathrm{H}, \mathrm{CH}_{2} \mathrm{CH}_{2} \mathrm{CH}_{3}\right)$.

\subsection{Refinement}

Crystal data, data collection and structure refinement details for (2), (4), (5) and (6) are summarized in Table 1. The structures were solved by direct methods using the program SHELXS (Sheldrick, 2008) and were refined with the 
Table 1

Experimental details.

(2)

Crystal data

Chemical formula

$M_{\mathrm{r}}$

Crystal system, space group

Temperature (K)

$a, b, c(\AA)$

$\alpha, \beta, \gamma\left({ }^{\circ}\right)$

$V\left(\AA^{3}\right)$

$Z$

Radiation type

$\mu\left(\mathrm{mm}^{-1}\right)$

Crystal size (mm)

Data collection

Diffractometer

Absorption correction

$T_{\min }, T_{\max }$

No. of measured, indepen-

dent and observed $[I>$ $2 \sigma(I)]$ reflections

$R_{\text {int }}$

$(\sin \theta / \lambda)_{\max }\left(\AA^{-1}\right)$

Refinement

$R\left[F^{2}>2 \sigma\left(F^{2}\right)\right], w R\left(F^{2}\right), S$

No. of reflections

No. of parameters

No. of restraints

$\mathrm{H}$-atom treatment

$\Delta \rho_{\max }, \Delta \rho_{\min }\left(\mathrm{e} \AA^{-3}\right)$

\section{$\left[\mathrm{PtCl}_{2}\left(\mathrm{C}_{15} \mathrm{H}_{20} \mathrm{O}_{4}\right)\left(\mathrm{C}_{9} \mathrm{H}_{7} \mathrm{~N}\right)\right]$}

659.45

Triclinic, $P \overline{1}$

100

8.1252 (3), 11.7042 (4),

$13.7340(5)$

65.864 (4), 84.716 (3),

$88.191(3)$

$1186.82(9)$

2

Mo $K \alpha$

6.17

$0.35 \times 0.10 \times 0.10$

Agilent SuperNova Dual Source diffractometer with an Eos detector

Multi-scan (CrysAlis PRO;

Agilent, 2013)

$0.432,1.000$

$19752,4867,4458$

\subsection{6}

0.625

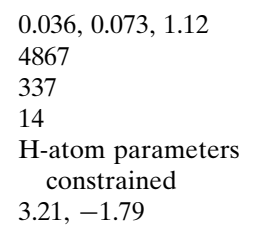

(4)

$\left[\mathrm{Pt}\left(\mathrm{C}_{9} \mathrm{H}_{6} \mathrm{NO}\right) \mathrm{Cl}\left(\mathrm{C}_{15} \mathrm{H}_{20} \mathrm{O}\right.\right.$
$\quad 33.00$
Triclinic, $P \overline{1}$
100
$8.3447(2), 11.9191(4)$,
$\quad 12.9315(5)$
$63.296(4), 84.618(3)$,
$\quad 76.484(3)$
$1117.09(7)$
2
$\mathrm{Mo} \mathrm{K \alpha}$
6.44
$0.25 \times 0.25 \times 0.10$

Agilent SuperNova Dual Source diffractometer with an Eos detector Multi-scan (CrysAlis PRO; Agilent, 2013)

$0.411,1.000$

$18255,4564,4417$

\subsection{9}

0.625

$0.021,0.048,1.09$
4564
291
0
H-atom parameters
$\quad$ constrained
$2.18,-1.45$

(5)

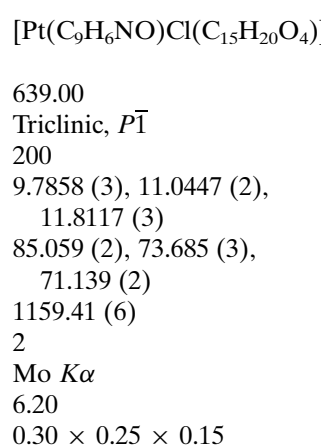

(6)

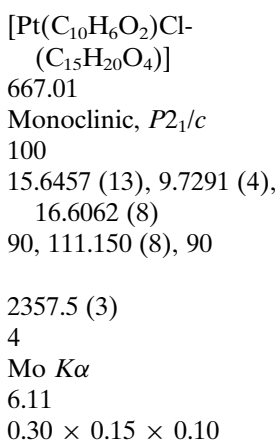

Agilent SuperNova Dual Source diffractometer with an Eos detector

Multi-scan (CrysAlis

PRO; Agilent, 2013)

$0.522,1.000$

21714, 4030, 3348

0.066

0.588

$0.038,0.086,1.08$

4030

316

0

H-atom parameters constrained $2.22,-1.14$

Computer programs: CrysAlis PRO (Agilent, 2013), SHELXS97 (Sheldrick, 2008), SHELXL2016 (Sheldrick, 2015) and OLEX2 (Dolomanov et al., 2009).

SHELXL (Sheldrick, 2015) refinement package using fullmatrix least-squares minimization. These programs were implemented within the OLEX2 package (Dolomanov et al., 2009). $\mathrm{H}$ atoms were placed in calculated positions and refined using a riding model, with $\mathrm{C}-\mathrm{H}=0.95$ (aromatic) and $0.98 \AA$ $\left(\mathrm{CH}_{3}\right)$, and $U_{\text {iso }}(\mathrm{H})=1.5 U_{\text {eq }}(\mathrm{C})$ for methyl $\mathrm{H}$ atoms and $1.2 U_{\text {eq }}(\mathrm{C})$ otherwise.

In complex (2), atoms $\mathrm{Pt} 1, \mathrm{Cl} 2, \mathrm{Cl} 3, \mathrm{C} 14$ and $\mathrm{C} 15$ are disordered, with occupancies converging to $0.656(8)$ and 0.344 (8) for the two positions ( $A$ and $B$ ). The distances C14$\mathrm{C} 15$ and $\mathrm{C} 15-\mathrm{C} 16$ for both sets were restrained to be equal (SADI command in SHELXL), and atoms C14B and C15B were restrained to approximate isotropic behaviour (ISOR command in SHELXL). In complex (6), atoms Pt1 and Cl2 show disorder, with occupancies of 0.930 (1) and 0.070 (1) for the two positions $(A$ and $B$ ). The same anisotropic displacement parameters were used for atoms $\mathrm{Pt} 1 A / B$ and $\mathrm{Cl} 2 A / B$ (EADP command in SHELXL).

\subsection{In vitro cell tests}

An MTT assay was used to determine the cytotoxic activity of compounds (2)-(6) with human cancer cell lines (KB, LU-1,
Hep-G2 and MCF-7) acquired from the American Type Culture Collection (ATCC, Manassas, VA). Cells were cultured in medium RPMI 1640 supplemented with $10 \%$ FBS (Fetal bovine serum) under a humidified atmosphere of $5 \%$ $\mathrm{CO}_{2}$ at $37^{\circ} \mathrm{C}$.

Compounds (2)-(6) were dissolved in DMSO at a concentration of $20 \mathrm{mg} \mathrm{ml}^{-1}$. A series of dilutions for each compound was prepared to final concentrations of $128,32,8,2$ and $0.5 \mu \mathrm{g} \mathrm{ml}^{-1}$. Samples $(100 \mu \mathrm{l})$ of the complexes with different concentrations were added to the wells on 96-well plates. Cells were separated with trypsin and EDTA, and seeded in each well with $3 \times 10^{4}$ cells per well. An MTT solution $(20 \mu \mathrm{l}$, $\left.4 \mathrm{mg} \mathrm{ml}^{-1}\right)$ of phosphate buffer saline $(8 \mathrm{~g} \mathrm{NaCl}, 0.2 \mathrm{~g} \mathrm{KCl}$, $1.44 \mathrm{~g} \mathrm{Na}_{2} \mathrm{HPO}_{4}$ and $0.24 \mathrm{~g} \mathrm{KH}_{2} \mathrm{PO}_{4}$ per 1) was added to each well after being incubated for $48 \mathrm{~h}$. The cells were further incubated for $4 \mathrm{~h}$ and a purple formazan precipitate was formed, which was separated by centrifugation. The precipitate was dissolved by adding DMSO $(100 \mu$ l) to each well. The optical density of the solution was determined by a plate reader (TECAN) at $540 \mathrm{~nm}$. The inhibition ratio was achieved on the basis of the optical densities from the calculation of three replicate tests. 


\section{Results and discussion}

\subsection{Synthesis and structure of complexes (1)-(6)}

Complexes $\mathrm{K}\left[\mathrm{PtCl}_{3}(\mathrm{AlkEug})\right]$ [AlkEug: PrEug (1a) or ${ }^{i}$ PrEug (1b)] were synthesized by the reaction between Zeise's salt and either PrEug or ${ }^{\mathrm{i}}$ PrEug, respectively (Chi et al., 2013; Thong \& Chi, 2014). The reactions were carried out at 313$318 \mathrm{~K}$ in propan-1-ol for (1a) and in an acetone-propan-2-ol $(1: 1 v / v)$ mixture for $(\mathbf{1 b})$ in $2-3 \mathrm{~h}$ with high yields $(92-95 \%)$. Encouraged by the effective synthetic procedure of $\mathrm{K}\left[\mathrm{PtCl}_{3}-\right.$ (eugenol)] by the interaction between Zeise's salt and eugenol without solvent at room temperature (Chi et al., 2017b), we applied this protocol for producing (1a) and (1b) in this research and obtained the products with the same yields (93$95 \%)$.<smiles></smiles>

2: $\mathrm{R}=\mathrm{CH}_{2} \mathrm{COOCH}_{2} \mathrm{CH}_{2} \mathrm{CH}_{3}$ 3: $\mathrm{R}=\mathrm{CH}_{2} \mathrm{COOCH}\left(\mathrm{CH}_{3}\right)_{2}$

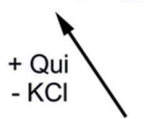<smiles>[R]Oc1ccc(C[13CH2][R](Cl)(Cl)[13CH2][2H])cc1OC</smiles>

1a: $\mathrm{R}=\mathrm{CH}_{2} \mathrm{COOCH}_{2} \mathrm{CH}_{2} \mathrm{CH}_{3}$ 1b: $\mathrm{R}=\mathrm{CH}_{2} \mathrm{COOCH}\left(\mathrm{CH}_{3}\right)_{2}$

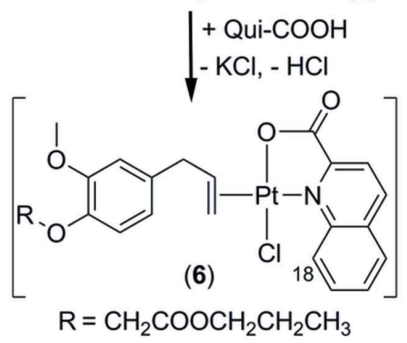

Scheme 2

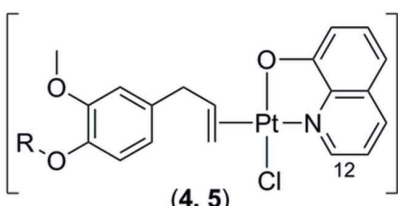

$(4,5)$ 4: $\mathrm{R}=\mathrm{CH}_{2} \mathrm{COOCH}_{2} \mathrm{CH}_{2} \mathrm{CH}_{3}$ 5: $\mathrm{R}=\mathrm{CH}_{2} \mathrm{COOCH}\left(\mathrm{CH}_{3}\right)_{2}$

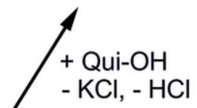


and (6), and the partial positive mass spectrum of (5) are shown in Fig. 1 as representatives.

The data in Table 2 show that base peaks with a relative intensity of $100 \%$ at $\mathrm{m} / \mathrm{z} 1022$ au (Fig. 1a), consistent with pseudomolecular anions $[2(M-\text { Qui }-\mathrm{HCl})+\mathrm{Cl}]^{-}$, i.e. $\left[\mathrm{Pt}_{2} \mathrm{Cl}_{3}(\text { AlkEug- } 1 \mathrm{H})_{2}\right]^{-}$, were observed in the ESI mass spectra of complexes (2)-(3). This provides evidence for the proposed quinoline coordination. For (4)-(6), the pseudomolecular cations $[M-\mathrm{Cl}]^{+}$, with a relative intensity of $100 \%$, i.e. $[\mathrm{Pt}(\text { amine })(\mathrm{AlkEug})]^{+}($Fig. $1 b)$, and $[M-\mathrm{AlkEug}+\mathrm{Cl}]^{-}$ peaks $(25-75 \%)$, i.e. $\left[\mathrm{PtCl}_{2} \text { (amine) }\right]^{-}$(Fig. 1c), were detected in the ESI mass spectra, showing the presence of AlkEug and the amines in these complexes.

In addition, the assigned results have established two unambiguous rules for the formation of pseudomolecular ions in the mass spectra of (2)-(6). Specifically, in the negative-ion mode, complexes (2) and (3), bearing the monodentate amine (Qui), tend to combine together to create the dimeric complexes $\left[\mathrm{Pt}_{2} \mathrm{Cl}_{2}(\mathrm{AlkEug}-1 \mathrm{H})_{2}\right]$. These dimers further combine with $\mathrm{Cl}^{-}$to form the pseudomolecular anions $\left[\mathrm{Pt}_{2} \mathrm{Cl}_{3}(\text { AlkEug- } 1 \mathrm{H})_{2}\right]^{-}$with the highest intensity in the negative-mode mass spectra (see Scheme 3 ). The formation of the analogous pseudomolecular ion, $\left[\mathrm{Pt}_{2} \mathrm{Cl}_{3}(\mathrm{Eug}-1 \mathrm{H})_{2}\right]^{-}$, was also observed in the negative mode ESI-MS of $\left[\mathrm{Pt}_{2} \mathrm{Cl}_{2}\right.$ (Eug$\left.1 \mathrm{H})_{2}\right]$ (Chi et al., 2018).

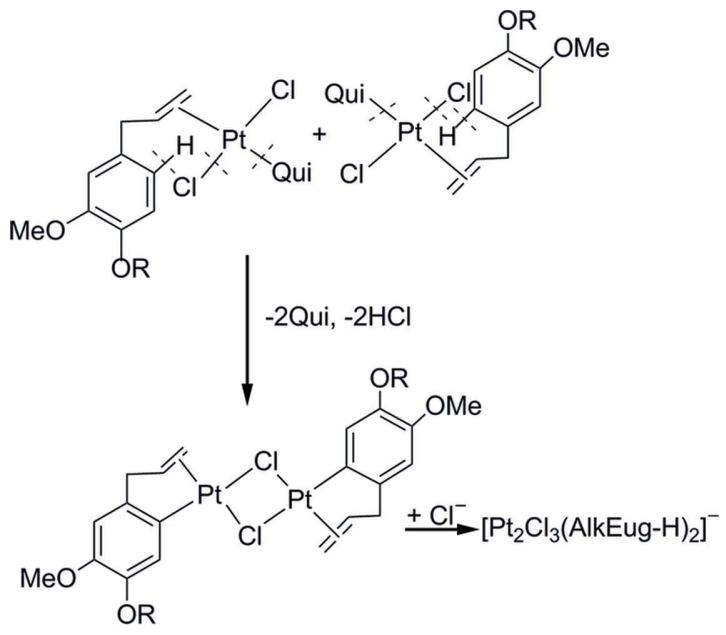

Scheme 3

Unlike (2) and (3), complexes (4)-(6), containing the chelating ligand Qui-O or Qui-COO, have no tendency to create pseudomolecular $\left[\mathrm{Pt}_{2} \mathrm{Cl}_{3}(\mathrm{AlkEug}-1 \mathrm{H})_{2}\right]^{-}$peaks in the -MS spectra, but form $[M-\mathrm{H}]^{-}$and $[M-\text { AlkEug }+\mathrm{Cl}]^{-}$ peaks with intensities of $25-75 \%$. Base peaks for the $[M-\mathrm{Cl}]^{+}$ cations and peaks with different intensities for the $[M+\mathrm{H}]^{+}$ cations were observed in all the + MS spectra of (4)-(6), as well as of their analogues (Table 2). This is associated with the reactions shown in Scheme 4.

The strong absorption band for $v_{\mathrm{C}=\mathrm{O}}$ at $1762-1751 \mathrm{~cm}^{-1}$ in the IR spectra of (2)-(6) shows the presence of AlkEug in the coordination sphere. Moreover, the absence of a band at $1640 \mathrm{~cm}^{-1}$ for $v_{(\mathrm{C}=\mathrm{C} \text { allyl })}$ indicates that the allyl group in (2)(6) has coordinated with $\mathrm{Pt}^{\mathrm{II}}$ in a $\eta^{2}$ manner. Besides, in the IR spectra of (4)-(6), there is no evidence for a $v_{\mathrm{OH}}$ band, indi- cating that quinolin-8-ol and quinoline-2-carboxylic acid have been deprotonated and coordinate to $\mathrm{Pt}^{\mathrm{II}}$ via the $\mathrm{N}$ and $\mathrm{O}$ atoms.

These deprotonation and coordination of Qui-OH and Qui$\mathrm{COOH}$ in (4)-(6) are not only observed in analogous platinum(II) complexes (Chi et al., 2017a,b; Da et al., 2015), but also in other platinum(II) complexes (Kato et al., 2002; Fang et al., 2016).

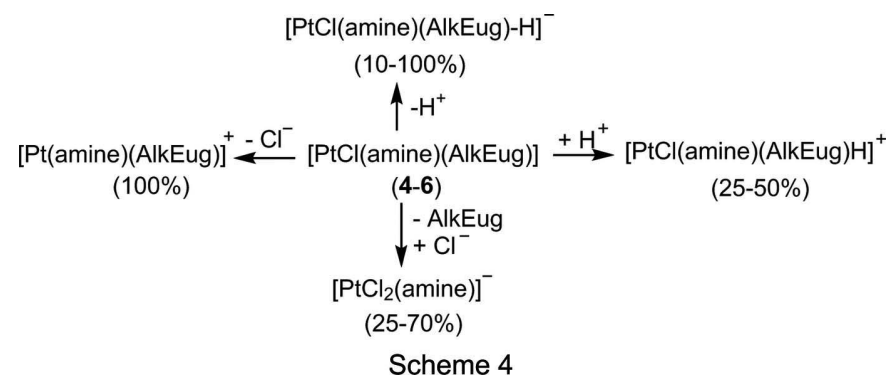

The proton signals are assigned based on their chemical shift $(\delta)$, intensity, shape and spin-spin splitting pattern. The results (see Experimental) demonstrate fully the proton signals of AlkEug and the amines present in (2)-(6). To elucidate the coordination of the ligands with $\mathrm{Pt}^{\mathrm{II}}$ in the examined complexes, the signals of the allyl protons of AlkEug, as well as $\mathrm{H} 12$ and H18 of the amines in (2)-(6), are listed in Table 3.

For free AlkEug, two $\mathrm{H} 8$ protons give rise to a doublet at $3.32 \mathrm{ppm}$, but in the spectra of (2)-(6), there are two separate signals (in the form of a doublet of doublets) for H8a and H8b. Moreover, the resonances of the ethylenic protons (H9 and H10) shift upfield in comparison to those of noncoordinated AlkEug and their ${ }^{195} \mathrm{Pt}$ satellites are clear $\left({ }^{2} J_{\mathrm{Pt}-\mathrm{H}}=70 \mathrm{~Hz}\right)$. All these observations are in good agreement with the observations in the spectra of complexes containing similar allylbenzenes $\left(\mathrm{Ar}-\mathrm{CH}_{2}-\mathrm{CH}=\mathrm{CH}_{2}\right)(\mathrm{Chi}$ et al., 2017a,b; Da et $a l ., 2015)$ and indicate that AlkEug in (2)-(6) have coordinated with $\mathrm{Pt}^{\mathrm{II}}$ via the allyl group as a $\eta^{2}$ ligand. Fig. 2 presents

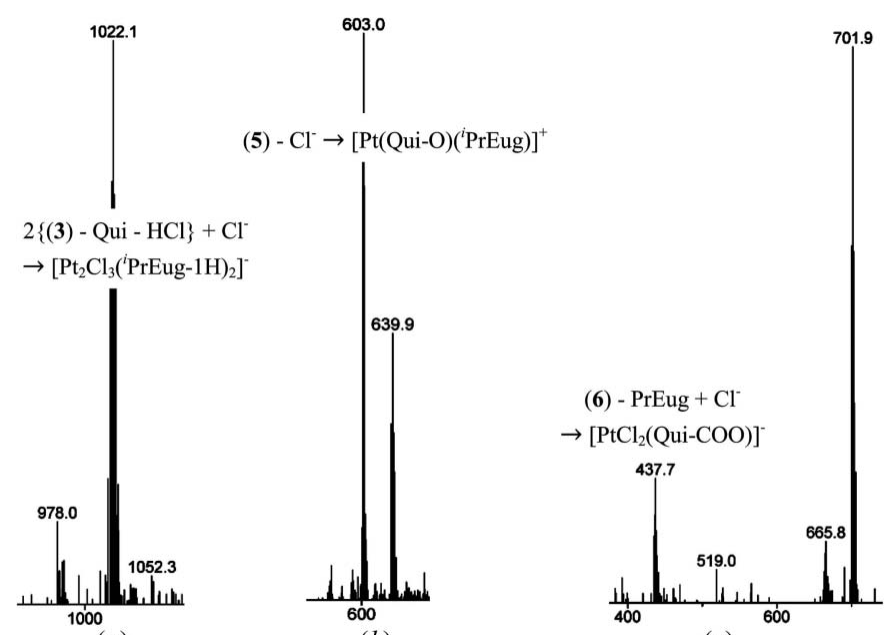

(c)

Figure 1

A partial negative mass spectra of $(a)(3)$ and $(c)(6)$, and a partial positive spectrum of $(b)(\mathbf{5})$. 
Table 3

Chemical shift (ppm), multiplicity and coupling constant $J_{\mathrm{Pt}-\mathrm{H}}(\mathrm{Hz})$ of atoms H8, H9, H10, H12 and H18 in free AlkEug and in (1)-(6) .

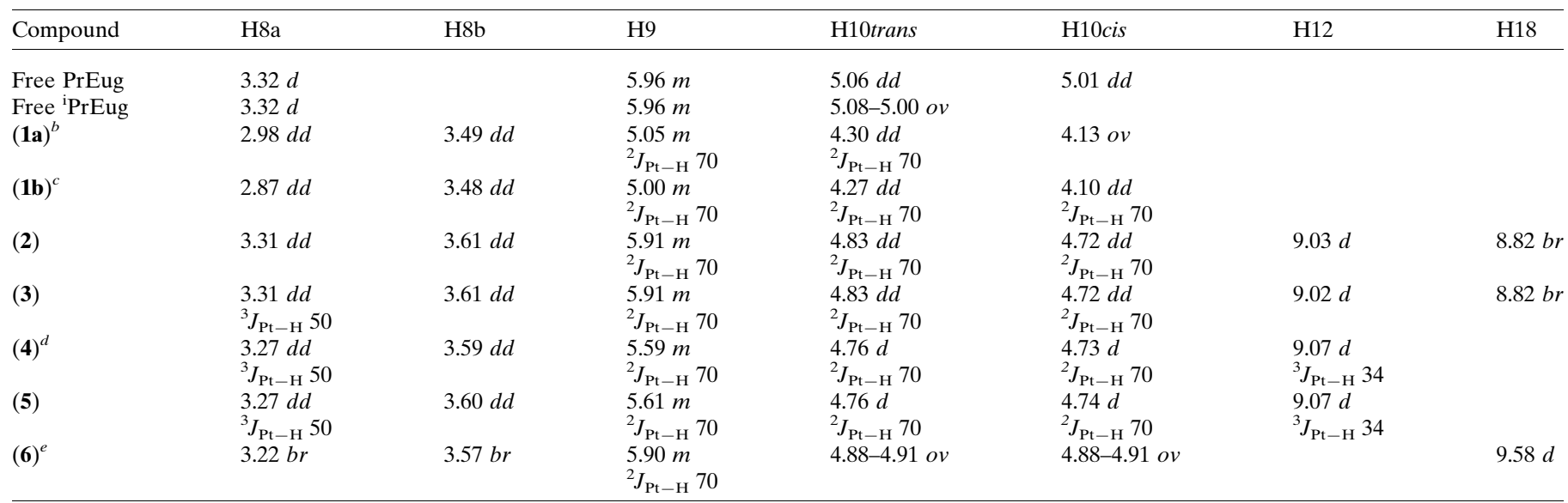

Notes/references: (a) acetone- $d_{6}$; (b) Chi et al. (2013); (c) Thong \& Chi (2014); (d) Chi et al. (2014); (e) chloroform- $d_{1}$.

the signals of the allyl protons and H12 and H18 in (3) as an example.

Upon coordination of the amines with $\mathrm{Pt}^{\mathrm{II}}$, all the resonances of the ethylenic protons of AlkEug shift remarkably downfield compared to the parent complex (1a) [for (2), (4) and (6)] and (1b) [for (3) and (5)] (Table 3). Two ${ }^{195} \mathrm{Pt}$ satellites in the doublet at 9.07 ppm from H12 of Qui-O in (4) and (5) are clear, with a ${ }^{3} J_{\mathrm{Pt}-\mathrm{H}}$ value of $34 \mathrm{~Hz}$ [for (2) and (3), the ${ }^{195} \mathrm{Pt}$ satellites in the signal of $\mathrm{H} 12$ are broadened beyond detection (Fig. 2)]. This value is comparable in magnitude to ${ }^{3} J_{\mathrm{Pt}-\mathrm{H}}$ in analogous platinum(II) complexes (Chi et al., 2017a,b; Da et al., 2015). The signal of H18 in (2) and (3) becomes broadened (Fig. 2). This may be due to the anisotropic effect of the $\mathrm{Pt}-\left(\mathrm{C}=\mathrm{C}_{\text {allyl }}\right)$ bond on the quinoline ligand, depending on the orientation of the quinoline plane with respect to the coordination plane of $\mathrm{Pt}^{\mathrm{II}}$. In addition, the signal at $9.58 \mathrm{ppm}$ of H18 in (6) is significantly downfield compared to quinoline2-carboxylic acid (8.01 ppm).

In order to confirm the configuration of the examined complexes and to determine concretely the position of the donor $\mathrm{N}$ atom of the quinoline derivatives in the coordination entity, as well as the molecular arrangement of the complexes, single-crystal X-ray diffraction was initiated.

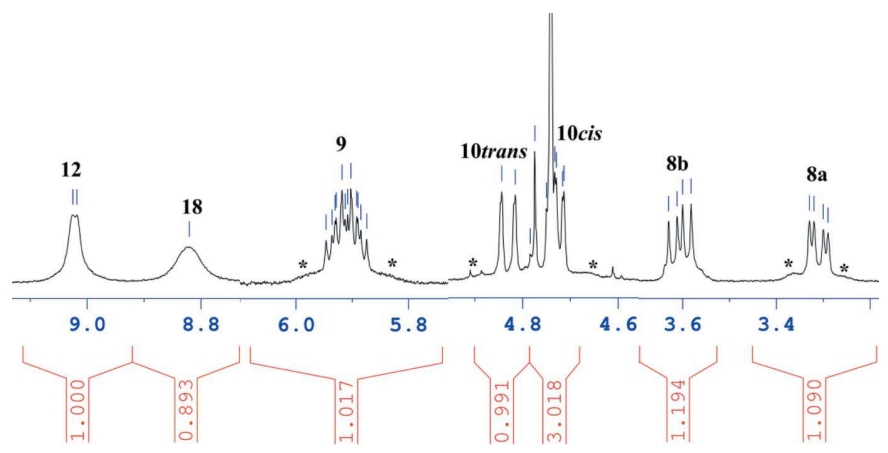

Figure 2

A partial ${ }^{1} \mathrm{H}$ NMR spectrum of $(3) ;{ }^{195} \mathrm{Pt}$ satellites are indicated by asterisks $(*)$.

\subsection{Crystal structures of complexes (2), (4)-(6)}

Complexes (2), (4) and (5) crystallize in the triclinic space group $P \overline{1}$, whereas complex (6) crystallizes in the monoclinic space group $P 2_{1} / c$. The central $\mathrm{Pt}^{\mathrm{II}}$ atom in (2) displays a distorted square-planar coordination with a trans positioning of the two $\mathrm{Cl}$ atoms (Fig. 3). The coordination is further completed by the $\mathrm{N}$ atom of quinoline and the $\mathrm{C}=\mathrm{C}$ double bond of PrEug. Part of the complex (atoms Pt1, Cl2, Cl3, C14 and $\mathrm{C} 15)$ is disordered, with population parameters of $0.656(8)$ and 0.344 (8) for positions $A$ and $B$, respectively. The dihedral angle between the best planes through the quinoline and phenyl rings is $74.4(2)^{\circ}$. An intramolecular $\mathrm{C}-\mathrm{H} \cdots \pi$ interaction is present (Fig. 3 and Table 4) and the packing is built up by $\mathrm{C}-\mathrm{H} \cdots \mathrm{O}$ (Table 4) and $\pi-\pi$ interactions

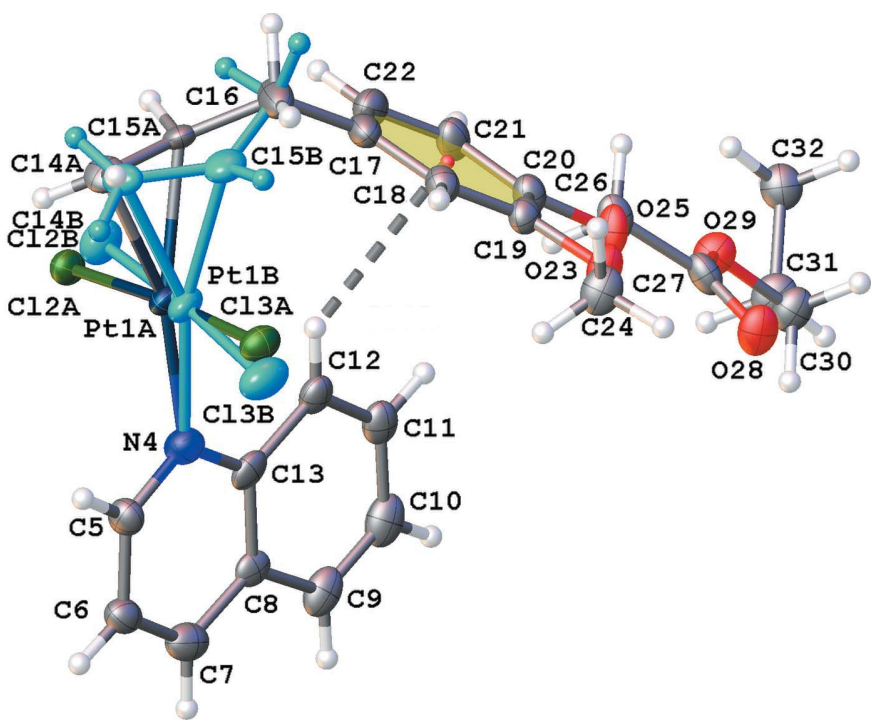

Figure 3

The molecular structure of complex (2), showing the atom-labelling scheme. Displacement ellipsoids are drawn at the $50 \%$ probability level. The fragment with a population parameter of 0.341 (8) is shown in blue and the intramolecular $\mathrm{C}-\mathrm{H} \cdots \pi$ interaction is shown as a grey dotted line. 


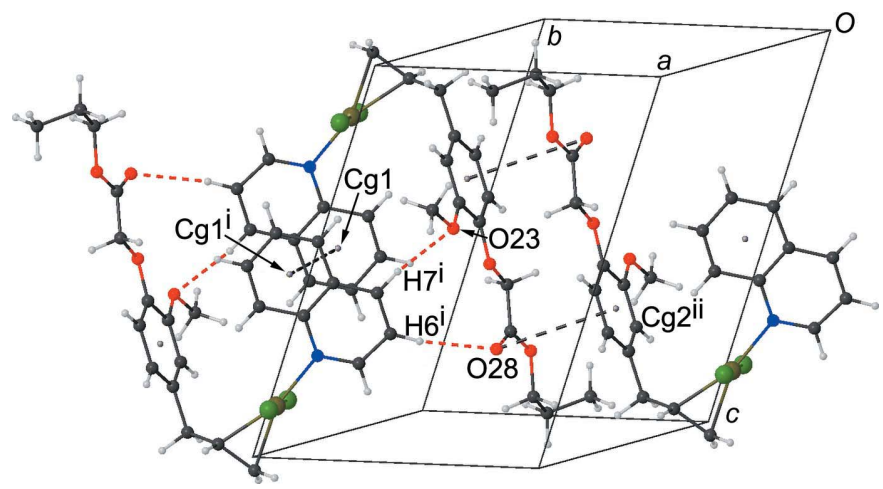

Figure 4

Packing diagram for (2), showing the $\mathrm{C}-\mathrm{H} \cdots \mathrm{O}$ (red dashed lines), $\pi-\pi$ (black) and $\mathrm{C}=\mathrm{O} \cdots \pi$ (black) interactions. [Symmetry codes: (i) $-x+2$, $-y+2,-z+1$; (ii) $-x+1,-y+1,-z+1$.]

$\left(C g 1 \cdots C g 1^{\mathrm{i}}=3.557\right.$ (3) $\AA$; $C g 1$ is the centroid of ring C8-C13; symmetry code: (i) $-x+2,-y+2,-z+1$; Fig. 4). Atom $\mathrm{O} 28$ interacts with the phenyl ring of PrEug $\left[\mathrm{O} 28 \cdots \mathrm{Cg} 2^{\mathrm{ii}}=\right.$ 3.978 (4) $\AA$; $C g 2$ is the centroid of ring C17-C22; symmetry code: (ii) $-x+1,-y+1,-z+1$; Fig. 4].

In complex (4), the quinoline ligand is now replaced by quinolin-8-ol. The crystal structure determination confirms the deprotonation of quinolin-8-ol and the $\mathrm{Pt}^{\mathrm{II}}$ coordination consisting of a $\mathrm{Cl}$ atom, the $\mathrm{C}=\mathrm{C}$ double bond of PrEug and the $\mathrm{N}$ and $\mathrm{O}$ atoms of quinolin-8-olate (with the $\mathrm{C}=\mathrm{C}$ double bond and $\mathrm{N}$ atom trans with respect to each other) (Fig. 5). The dihedral angle between the best planes through the quinoline and phenyl rings is $78.70(14)^{\circ}$. Centrosymmetric dimers are formed at one end by ring-metal interactions

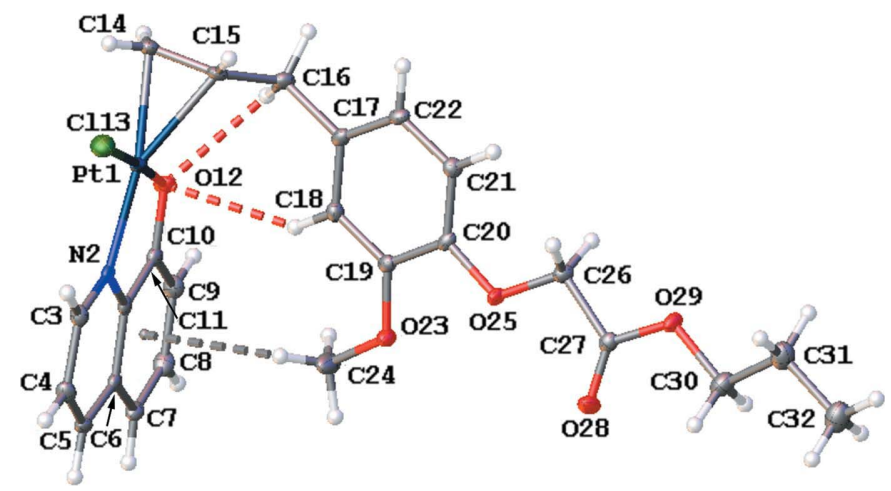

Figure 5

The molecular structure of complex (4), showing the atom-labelling scheme. Displacement ellipsoids are drawn at the $50 \%$ probability level. Intramolecular $\mathrm{C}-\mathrm{H} \cdots \mathrm{O}$ interactions are shown as red dotted lines and the intramolecular $\mathrm{C}-\mathrm{H} \cdots \pi$ interaction is shown as a grey dotted line.

Table 4

Hydrogen-bond geometry $\left(\AA,^{\circ}\right)$ for (2).

$C g 1$ is the centroid of ring $\mathrm{C} 17-\mathrm{C} 22$.

\begin{tabular}{lllll}
\hline$D-\mathrm{H} \cdots A$ & $D-\mathrm{H}$ & $\mathrm{H} \cdots A$ & $D \cdots A$ & $D-\mathrm{H} \cdots A$ \\
\hline $\mathrm{C} 6-\mathrm{H} 6 \cdots \mathrm{O} 28^{\text {ii }}$ & 0.95 & 2.47 & $3.404(7)$ & 169 \\
$\mathrm{C} 7-\mathrm{H} 7 \cdots \mathrm{O} 23^{\text {ii }}$ & 0.95 & 2.39 & $3.324(7)$ & 168 \\
$\mathrm{C} 24-\mathrm{H} 24 B \cdots \mathrm{O} 23^{\text {iiii }}$ & 0.98 & 2.53 & $3.287(6)$ & 134 \\
$\mathrm{C} 12-\mathrm{H} 12 \cdots C g 1$ & 0.95 & 2.93 & $3.732(6)$ & 142 \\
\hline
\end{tabular}

Symmetry codes: (i) $-x+2,-y+2,-z+1$; (ii) $-x+2,-y+1,-z+1$.

$\left[C g 1 \cdots \mathrm{Pt} 1^{\mathrm{i}}=3.985 \AA, C g 1\right.$ is the centroid of ring $\mathrm{C} 6-\mathrm{C} 11$; symmetry code: (i) $-x,-y+2,-z+1]$ and $\mathrm{C}-\mathrm{H} \cdots \pi$ interactions (Table 5), and at the other end by $\mathrm{C}-\mathrm{H} \cdots \pi$ inter-

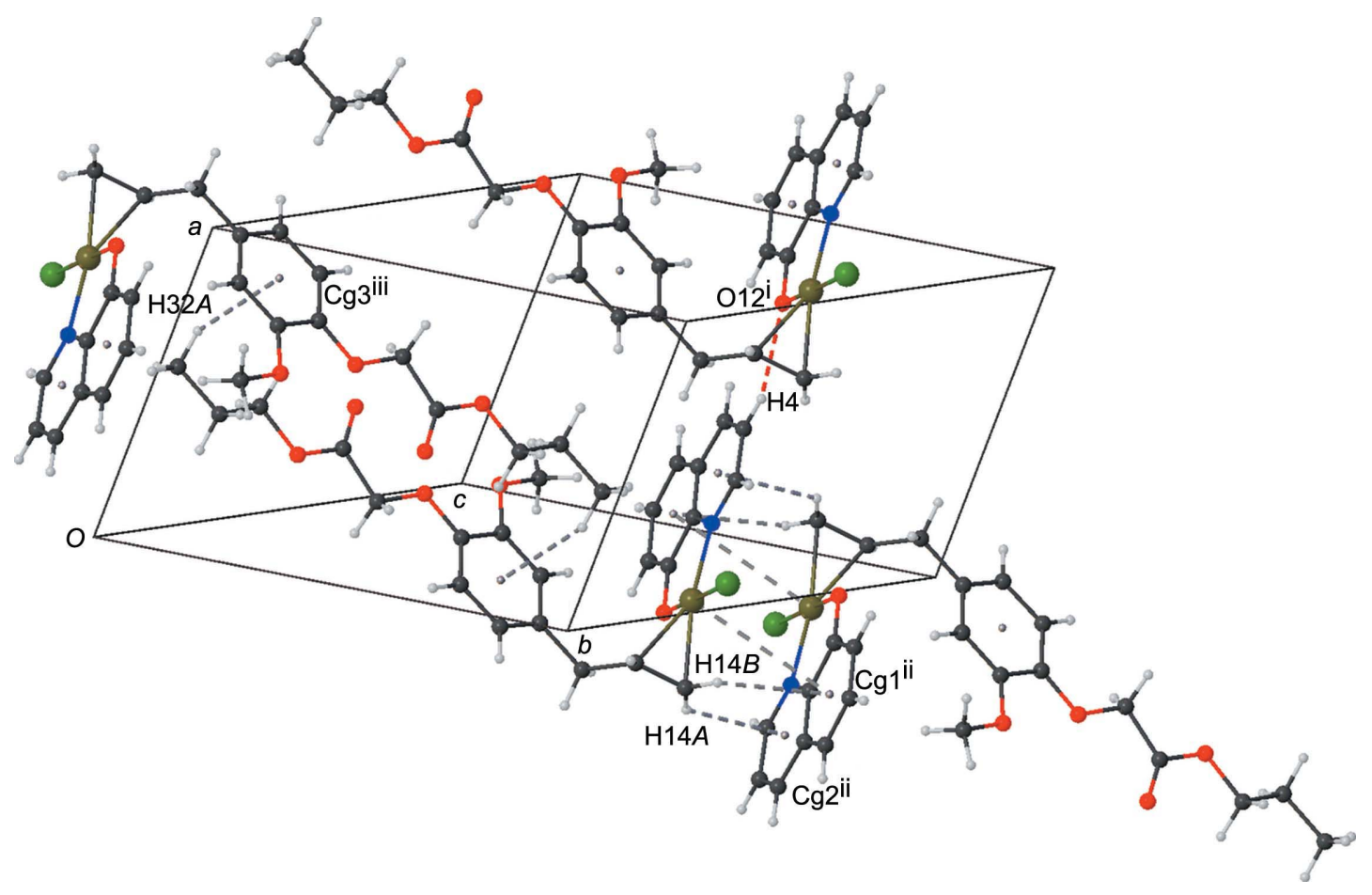

Figure 6

Packing diagram for (4), showing dimer formation at both ends of the complex through $\mathrm{C}-\mathrm{H} \cdots \pi$ interactions (grey dotted lines). Parallel chains interact through $\mathrm{C}-\mathrm{H} \cdots \mathrm{O}$ interaction (red dotted line). Symmetry codes are as given in Table 5. 


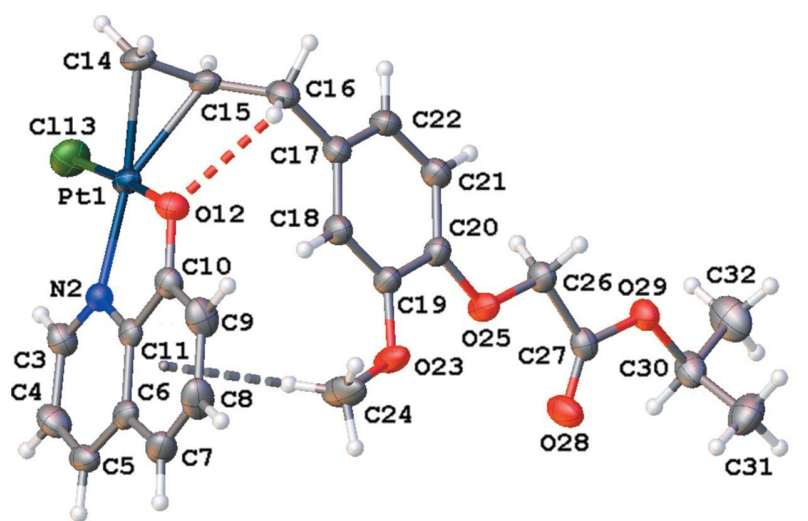

Figure 7

The molecular structure of complex (5), showing the atom-labelling scheme. Displacement ellipsoids are drawn at the $50 \%$ probability level. An intramolecular $\mathrm{C}-\mathrm{H} \cdots \mathrm{O}$ interaction is shown as a red dotted line and the intramolecular $\mathrm{C}-\mathrm{H} \cdots \pi$ interaction is shown as a grey dotted line.

actions (Table 5). Neighbouring chains interact via $\mathrm{C}-\mathrm{H} \cdots \mathrm{O}$ interactions (Table 5 and Fig. 6).

The molecular structure of (5) is very similar to that of complex (4) (Fig. 7). Fitting both structures, omitting the propyl groups, gives an r.m.s. deviation of $0.137 \AA$. The dihedral angle between the best planes through the quinoline and phenyl rings is $75.37(13)^{\circ}$. Similar centrosymmetric dimers are formed in the crystal packing (Fig. 8 and Table 6). However, no ring-metal interaction is present as the two $\mathrm{Pt}^{\mathrm{II}}$ ends in the dimer are shifted compared to complex (4). A further consequence of this shifting is that only one of the vinyl $\mathrm{H}$ atoms is involved in a $\mathrm{C}-\mathrm{H} \cdots \pi$ interaction and that
Table 5

Hydrogen-bond geometry $\left(\AA,^{\circ}\right)$ for (4).

$C g 1$ is the centroid of ring $\mathrm{C} 6-\mathrm{C} 11, C g 2$ is the centroid of ring N2/C3-C6/C11 and $C g 3$ is the centroid of ring $\mathrm{C} 17-\mathrm{C} 22$.

\begin{tabular}{lllll}
\hline$D-\mathrm{H} \cdots A$ & $D-\mathrm{H}$ & $\mathrm{H} \cdots A$ & $D \cdots A$ & $D-\mathrm{H} \cdots A$ \\
\hline $\mathrm{C} 16-\mathrm{H} 16 B \cdots \mathrm{O} 12$ & 0.99 & 2.45 & $3.070(4)$ & 120 \\
$\mathrm{C} 18-\mathrm{H} 18 \cdots \mathrm{O} 12$ & 0.95 & 2.57 & $3.352(5)$ & 140 \\
$\mathrm{C} 4-\mathrm{H} 4 \cdots \mathrm{O} 12^{\mathrm{i}}$ & 0.95 & 2.57 & $3.488(4)$ & 163 \\
$\mathrm{C} 14-\mathrm{H} 14 A \cdots C g 2^{\mathrm{ii}}$ & 0.93 & 2.94 & $3.581(4)$ & 127 \\
$\mathrm{C} 14-\mathrm{H} 14 B \cdots C g 1^{\text {ii }}$ & 0.93 & 2.88 & $3.493(4)$ & 125 \\
$\mathrm{C} 24-\mathrm{H} 24 C \cdots C g 1$ & 0.98 & 2.91 & $3.513(5)$ & 121 \\
$\mathrm{C} 32-\mathrm{H} 32 A \cdots C g 3^{\text {iii }}$ & 0.98 & 2.84 & $3.655(5)$ & 141 \\
\hline
\end{tabular}

Symmetry codes: (i) $x+1, y, z$; (ii) $-x,-y+2,-z+1$; (iii) $-x+1,-y+1,-z$.

Table 6

Hydrogen-bond geometry $\left(\AA,^{\circ}\right)$ for (5).

$C g 1$ is the centroid of ring N2/C3-C6/C11, $C g 2$ is the centroid of ring $\mathrm{C} 6-\mathrm{C} 11$ and $\mathrm{Cg} 3$ is the centroid of ring $\mathrm{C} 17-\mathrm{C} 22$.

\begin{tabular}{lllll}
\hline$D-\mathrm{H} \cdots A$ & $D-\mathrm{H}$ & $\mathrm{H} \cdots A$ & $D \cdots A$ & $D-\mathrm{H} \cdots A$ \\
\hline $\mathrm{C} 5-\mathrm{H} 5 \cdots \mathrm{O} 23^{\mathrm{i}}$ & 0.95 & 2.46 & $3.073(4)$ & 122 \\
$\mathrm{C} 16-\mathrm{H} 16 A \cdots \mathrm{O} 12$ & 0.99 & 2.40 & $3.051(4)$ & 123 \\
$\mathrm{C} 14-\mathrm{H} 14 B \cdots C g 1^{\text {ii }}$ & 0.99 & 2.94 & $3.454(4)$ & 114 \\
$\mathrm{C} 24-\mathrm{H} 24 B \cdots C g 2$ & 0.98 & 2.93 & $3.564(4)$ & 124 \\
$\mathrm{C} 30-\mathrm{H} 30 \cdots C g 3^{\text {iii }}$ & 1.00 & 2.96 & $3.827(4)$ & 145 \\
\hline
\end{tabular}

Symmetry codes: (i) $-x,-y+1,-z+1$; (ii) $-x-1,-y,-z+1$; (iii) $-x+1,-y$, $-z+1$.

the $\mathrm{C}-\mathrm{H} \cdots \mathrm{O}$ interactions between neighbouring chains are now through atom $\mathrm{O} 23$ and not $\mathrm{O} 12$ as in (4).

In complex (6), the quinoline ligand is replaced by quinoline-2-carboxylic acid which is deprotonated and coordinates to $\mathrm{Pt}^{\mathrm{II}}$ through the $\mathrm{N}$ and $\mathrm{O}$ atoms (Fig. 9). The $\mathrm{Pt}^{\mathrm{II}}$ coordi-

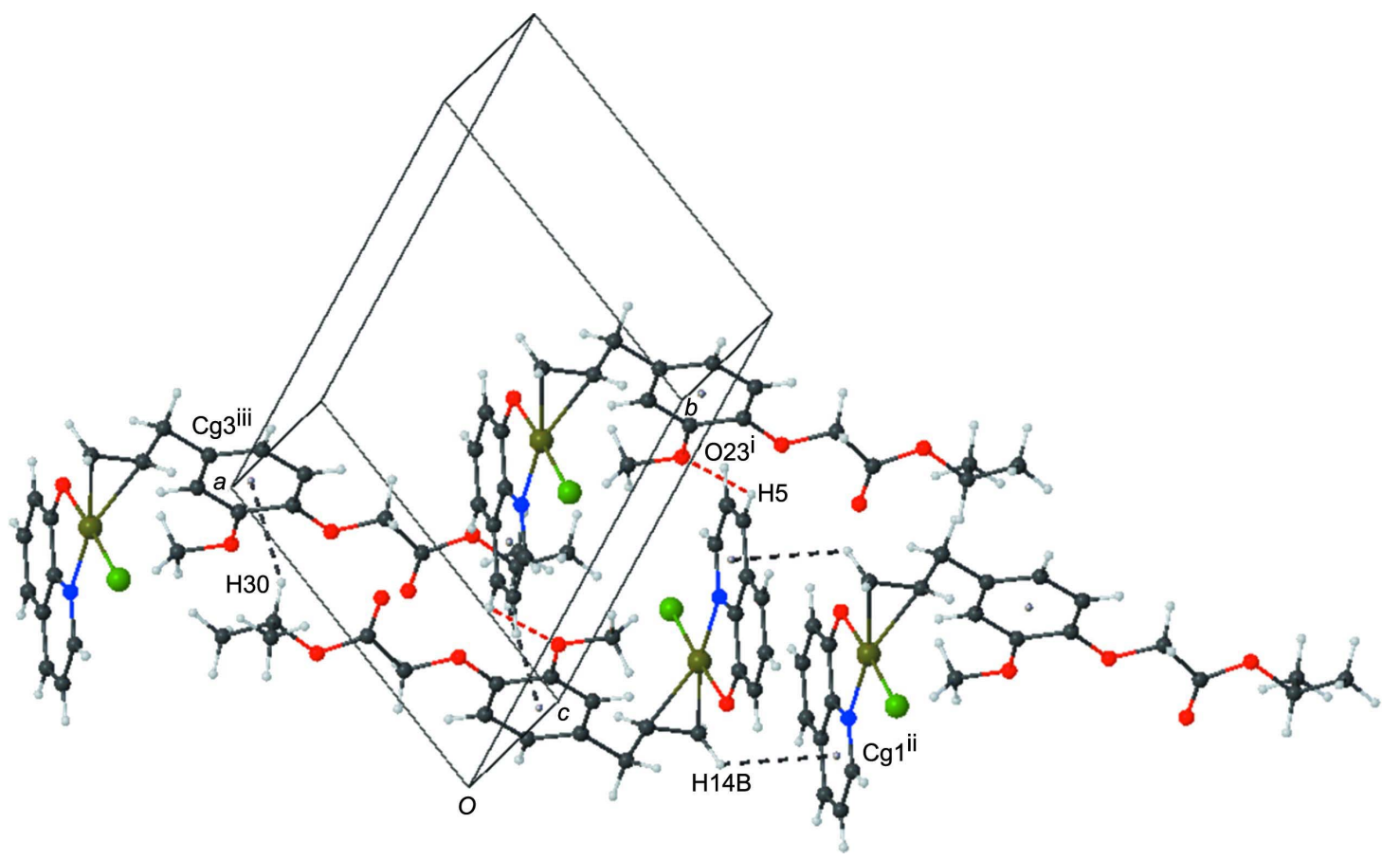

Figure 8

Packing diagram for (5), showing dimer formation at both ends of the complex through $\mathrm{C}-\mathrm{H} \cdots \pi$ interactions (grey dotted lines). Parallel chains interact through $\mathrm{C}-\mathrm{H} \cdots \mathrm{O}$ interactions (red dotted line). Symmetry codes are as given in Table 6. 
Table 7

Hydrogen-bond geometry $\left(\AA,^{\circ}\right)$ for (6).

\begin{tabular}{lllll}
\hline$D-\mathrm{H} \cdots A$ & $D-\mathrm{H}$ & $\mathrm{H} \cdots A$ & $D \cdots A$ & $D-\mathrm{H} \cdots A$ \\
\hline $\mathrm{C} 11-\mathrm{H} 11 \cdots \mathrm{C} 2 A$ & 0.95 & 2.34 & $3.211(8)$ & 153 \\
$\mathrm{C} 11-\mathrm{H} 11 \cdots \mathrm{Cl} 2 B$ & 0.95 & 2.81 & $3.59(3)$ & 140 \\
$\mathrm{C} 16-\mathrm{H} 16 A \cdots \mathrm{O} 30^{\mathrm{i}}$ & 0.95 & 2.55 & $3.452(9)$ & 159 \\
$\mathrm{C} 20-\mathrm{H} 20 \cdots \mathrm{O} 30^{\mathrm{i}}$ & 0.95 & 2.59 & $3.524(9)$ & 167 \\
$\mathrm{C} 28-\mathrm{H} 28 B \cdots \mathrm{Cl} 2 A^{\mathrm{ii}}$ & 0.99 & 2.64 & $3.473(7)$ & 142 \\
$\mathrm{C} 32-\mathrm{H} 32 A \cdots \mathrm{O} 30^{\mathrm{iii}}$ & 0.99 & 2.52 & $3.459(10)$ & 158 \\
\hline
\end{tabular}

Symmetry codes: (i) $x,-y+\frac{3}{2}, z-\frac{1}{2}$; (ii) $x,-y+\frac{5}{2}, z+\frac{1}{2}$; (iii) $-x+2,-y+2,-z+3$.

nation is completed by a $\mathrm{Cl}$ atom and the $\mathrm{C}=\mathrm{C}$ double bond of PrEug (with the $\mathrm{C}=\mathrm{C}$ double bond and $\mathrm{N}$ atom trans with respect to each other). Part of the complex (atoms Pt1 and $\mathrm{Cl} 2$ ) is disordered, with population parameters of 0.930 (1) and 0.070 (1) for positions $A$ and $B$, respectively. Both $\mathrm{Cl}$ atoms are involved in an intramolecular $\mathrm{C}-\mathrm{H} \cdots \mathrm{Cl}$ interaction (Fig. 9 and Table 7). The dihedral angle between the best planes through the quinoline and phenyl rings is $70.6(3)^{\circ}$. The packing is built up by $\mathrm{C}-\mathrm{H} \cdots \mathrm{O}$ and $\mathrm{C}-\mathrm{H} \cdots \mathrm{Cl}$ interactions (Fig. 10 and Table 7), and $\pi-\pi$ interactions $\left[C g 1 \cdots C g 3^{\mathrm{i}}=3.807(5) \AA, C g 1 \cdots C g 1^{\mathrm{iv}}=3.942(4) \AA\right.$ and $C g 1 \cdots C g 2^{\text {iv }}=3.683(5) \AA ; C g 1, C g 2$ and $C g 3$ are the centroids of rings $\mathrm{N} 3 / \mathrm{C} 4-\mathrm{C} 7 / \mathrm{C} 12, \mathrm{C} 7-\mathrm{C} 12$ and $\mathrm{C} 19-\mathrm{C} 24$, respectively; symmetry codes: (i) $x,-y+\frac{3}{2}, z-\frac{1}{2}$; (iv) $-x+1,-y+2,-z+1$; Fig. 10].

\subsection{In vitro cytotoxicity of the examined complexes (2)-(6)}

The in vitro cytotoxicity of (2)-(6) against the four human tumour cell lines KB (Human epidemic carcinoma), Hep-G2

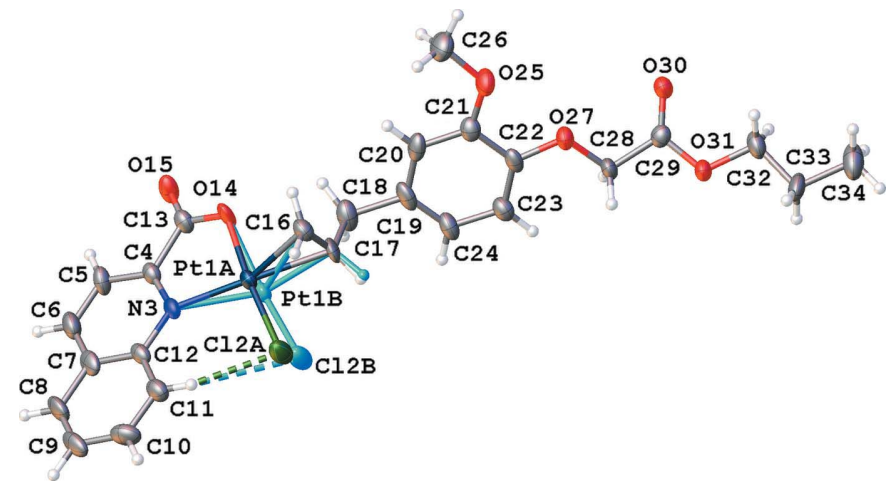

Figure 9

The molecular structure of complex (6), showing the atom-labelling scheme. Displacement ellipsoids are drawn at the $50 \%$ probability level. The fragment with a population parameter of 0.094 (7) is shown in blue and the intramolecular $\mathrm{C}-\mathrm{H} \cdots \mathrm{Cl}$ interactions are shown as dotted lines.

(Hepatocellular carcinoma), LU (Human lung carcinoma) and MCF-7 (Human breast carcinoma) were assessed by the MTT method. The $\mathrm{IC}_{50}$ values are listed in Table 8, together with literature data for some other platinum(II) complexes.

The reported complexes (2)-(6) have notably high activities against the four cancer cell lines, with $\mathrm{IC}_{50}$ values of 0.38 $29.23 \mu M$. A comparison among complexes (2)-(6) shows a clear trend on all four tested cell lines, with increasing $\mathrm{IC}_{50}$ values in the order from (4) and (5) $(0.38-1.99 \mu M)$ via (2) and (3) (4.27-7.02 $\mu M)$ to (6) $(7.27-29.23 \mu M)$. In other words, the in vitro cytotoxicities of the complexes bearing quinolin-8olate are the highest, followed by the complexes containing quinoline and finally the quinoline-2-carboxylate complex (Fig. 11). Moreover, comparisons between complexes (3) and

Figure 10

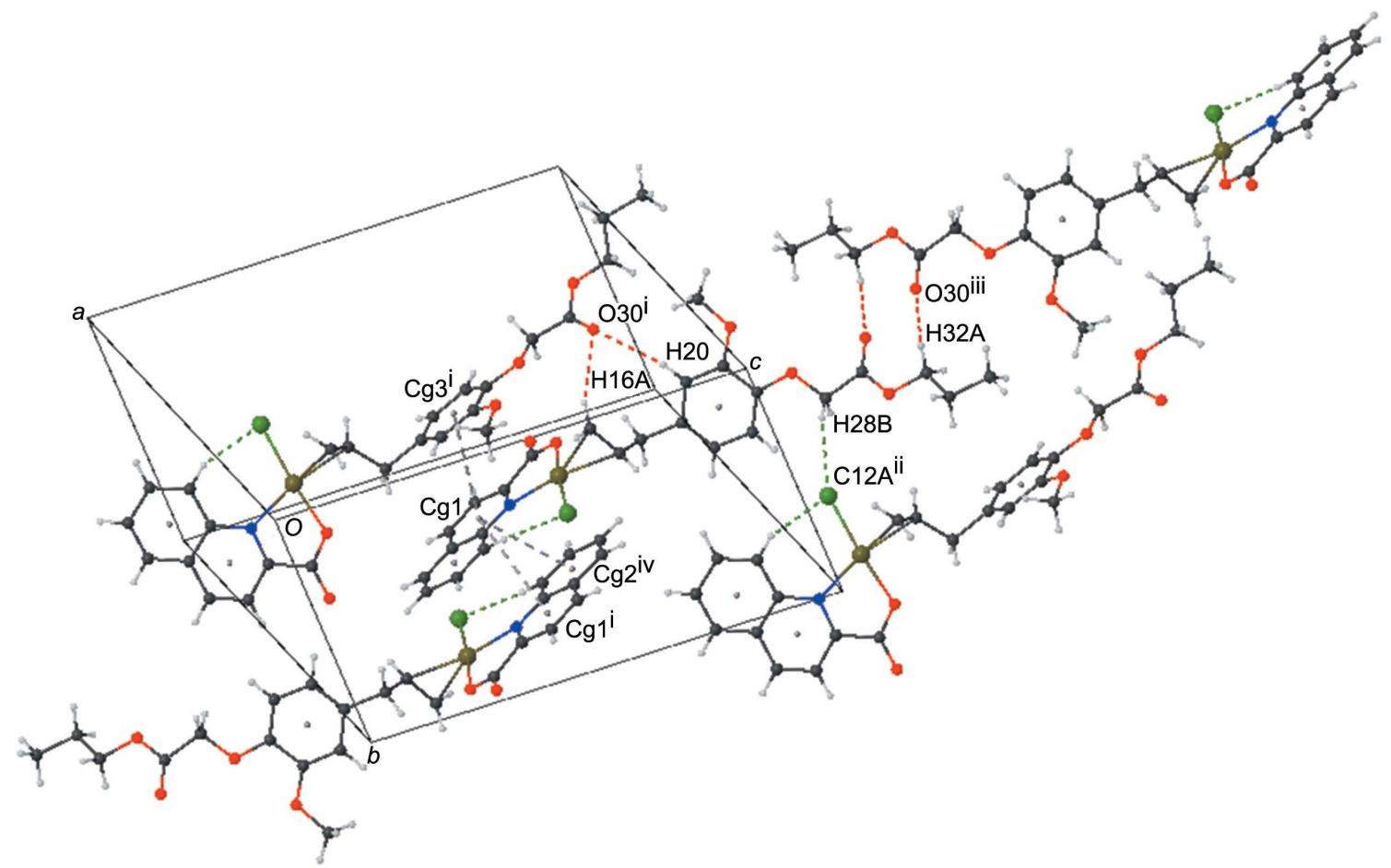

Packing diagram for $(\mathbf{6})$, showing the $\mathrm{C}-\mathrm{H} \cdots \mathrm{O}$ (red dashed lines), $\mathrm{C}-\mathrm{H} \cdots \mathrm{Cl}$ (green) and $\pi-\pi$ (black) interactions. Symmetry codes are as given in Table 7 and the text. 
Table 8

Cytotoxic effects of the examined compounds $\left(\mathrm{IC}_{50}{ }^{a}\right.$ in $\left.\mu M\right)$ and some reference compounds.

Values highlighted in bold are the lowest values.

\begin{tabular}{|c|c|c|c|c|}
\hline Compound & KB & LU & Hep-G2 & MCF-7 \\
\hline trans $-\left[\mathrm{PtCl}_{2}(\right.$ Preug $\left.)(\mathrm{Qui})\right],(\mathbf{2})$ & $4.27 \pm 0.09$ & $7.02 \pm 0.28$ & $6.64 \pm 0.20$ & $6.47 \pm 0.32$ \\
\hline trans $-\left[\mathrm{PtCl}_{2}\left({ }^{\mathrm{i}} \mathrm{Preug}\right)(\mathrm{Qui})\right],(\mathbf{3})$ & $5.09 \pm 0.18$ & $4.64 \pm 0.12$ & $5.96 \pm 0.30$ & $5.93 \pm 0.12$ \\
\hline$[\mathrm{PtCl}($ Qui-O)(Preug) $],(\mathbf{4})$ & $\mathbf{0 . 3 9} \pm 0.02$ & $\mathbf{1 . 2 5} \pm 0.05$ & $\mathbf{1 . 9 9} \pm 0.10$ & $\mathbf{1 . 5 5} \pm 0.06$ \\
\hline [PtCl(Qui-COO)(Preug)], (6) & $7.27 \pm 0.32$ & $18.60 \pm 0.37$ & $14.68 \pm 0.45$ & $29.23 \pm 1.24$ \\
\hline Ellipcitine & $1.26 \pm 0.03$ & $1.42 \pm 0.07$ & $2.15 \pm 0.09$ & $1.83 \pm 0.06$ \\
\hline$\left[\mathrm{PtCl}(\text { Qui-O)}(\text { olefin })]^{b}\right.$ & $0.43-1.39$ & $2.95-8.17$ & $5.29-9.58$ & $1.84-9.04$ \\
\hline Other $\mathrm{Pt}^{\mathrm{II}}$ & $5.98-22.54^{c}$ & & $3.4-85.37^{d}$ & $4.65-90.79^{e}$ \\
\hline
\end{tabular}

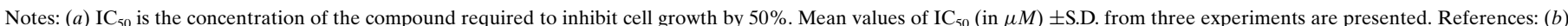

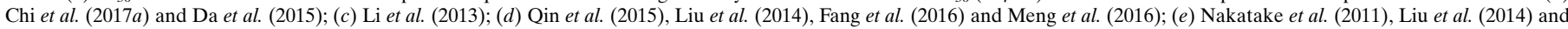
Abu-Safieh et al. (2016); $(f)$ Da et al. (2015); $(g)$ Chi et al. (2017a).

(5), and between (2) and (4), which differ solely in the amine group, reveal a trend that the complexes bearing Qui-O, i.e. (4) and (5), display a higher cytotoxicity on the tested cell lines (except the KB cell line) than the complexes containing Qui, i.e. (2) and (3) (Fig. 11).

Compared to analogs [PtCl(Qui-O)(olefin)] (olefin is eugenol or methyleugenol) (Da et al., 2015; Chi et al., 2017a) and other $\mathrm{Pt}^{\mathrm{II}}$ complexes (Li et al., 2013; Qin et al., 2015; Liu et al., 2014; Fang et al., 2016; Abu-Safieh et al., 2016; Meng et al., 2016; Nakatake et al., 2011), complexes (4) and (5) show better antitumour activities (Table 8). It is noteworthy that free Qui$\mathrm{OH}$ causes only a weak inhibition of the growth of the four cancer cell lines. This indicates that the $\mathrm{N}, \mathrm{O}$-chelated hydroxyquinolate ligand coordination causes a significant increase in the cytotoxicity of complexes (4) and (5), as well as of complexes [ $\mathrm{PtCl}\left(\right.$ Qui-O)(olefin)] (Fig. 12). The $\mathrm{IC}_{50}$ value of (5) for the $\mathrm{Lu}$ cell line is approximately 143 times lower than Qui-OH. In comparison with cisplatin, the $\mathrm{IC}_{50}$ values of complexes (4) and (5) are markedly lower, especially for the Lu and MCF-7 cell lines (approximately 30 times lower than cisplatin; Fig. 12).

\section{Conclusions}

In our search for more effective platinum-based anticancer drugs, we have synthesized five new $\mathrm{Pt}^{\mathrm{II}}$ complexes of type trans-[PtCl${ }_{2}$ (AlkEug)(Qui)], (2) and (3), and [PtCl(amine)(AlkEug)], (4)-(6), in excellent yields ( $\geq 89 \%$ ) by replacement of one $\mathrm{Cl}$ ligand in $\mathrm{K}\left[\mathrm{PtCl}_{3}(\mathrm{AlkEug})\right]$, (1), with quinoline, or of two $\mathrm{Cl}$ ligands with quinolin-8-ol or quinoline-2-carboxylic acid. The $\mathrm{Pt}^{\mathrm{II}}$ coordination was explored by NMR spectroscopy, IR spectroscopy, ESI mass spectroscopy and singlecrystal X-ray diffraction studies. The in vitro cytotoxicity of compounds (2)-(6), as well as of reference compounds, against the four human cancer cell lines KB, LU, Hep-G2 and MCF-7 was evaluated using the MTT assay. The results indicate that the excellent cytotoxicity (the $\mathrm{IC}_{50}$ values of $0.38-29.23 \mu \mathrm{M}$ ) depends on the amine ligand and increases in the order quinoline-2-carboxylate complex $(\mathbf{6})<$ quinoline complexes (2) and (3) < quinolin-8-olate complexes (4) and (5). The $\mathrm{IC}_{50}$

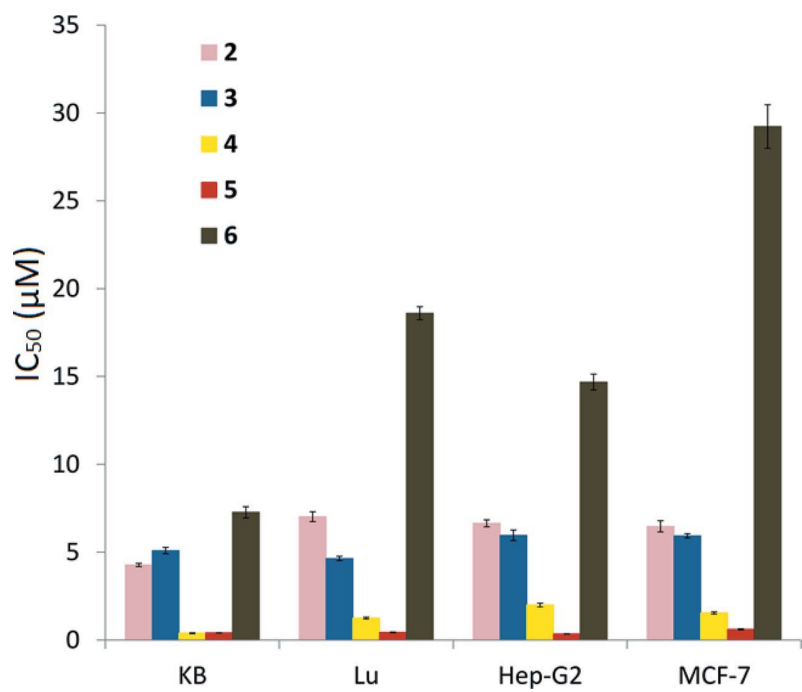

Figure 11

The cytotoxic effects ( $\mathrm{IC}_{50}$ values) of complexes (2)-(6) against the $\mathrm{KB}$, LU, Hep-G2 and MCF-7 cell lines.

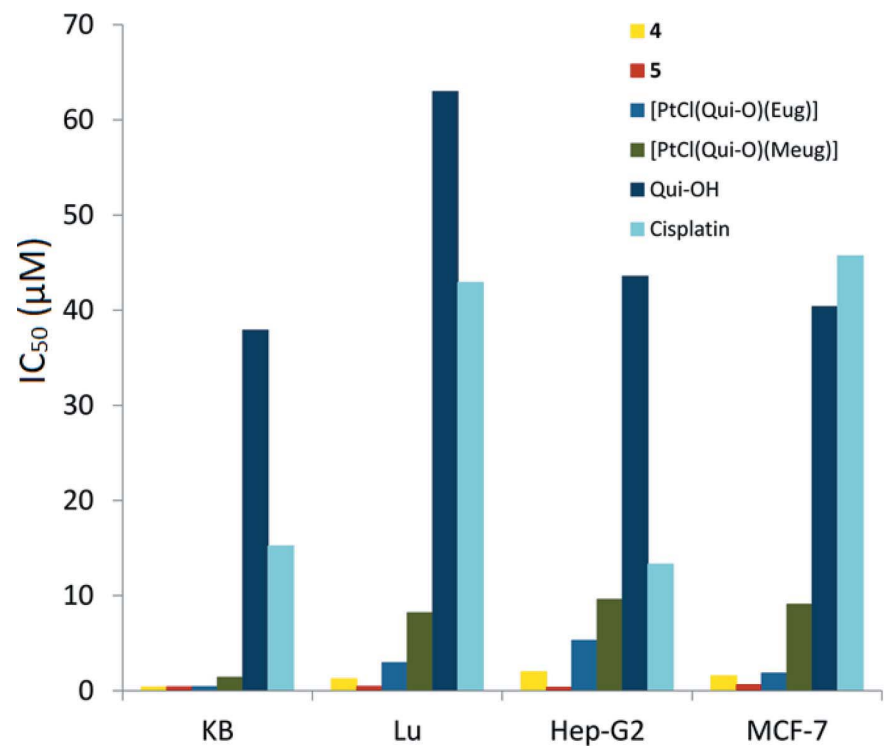

Figure 12

The cytotoxic effects $\left(\mathrm{IC}_{50}\right.$ values) of complexes (4), (5) and cisplatin against the KB, LU, Hep-G2 and MCF-7 cell lines. 
values of the most promising complex, i.e. (5), is at least 30 times lower than that of cisplatin. The significant inhibiting abilities on the four human cancer cell lines of these new complexes, as well as the unambiguous trend on the influence of the amine on the cytotoxicity, requires in a next phase a study of the anticancer mechanism of the complexes and the structure-function relationship.

\section{Acknowledgements}

The authors thank the Hercules Foundation for supporting the purchase of the diffractometer.

\section{Funding information}

Funding for this research was provided by: Hercules Foundation (award No. AKUL/09/0035).

\section{References}

Abu-Safieh, K. A., Abu-Surrah, A. S., Tabba, H. D., AlMasri, H. A., Bawadi, R. M., Boudjelal, F. M. \& Tahtamouni, L. H. (2016). J. Chem., article ID 7508724.

Agilent (2013). CrysAlis PRO. Agilent Technologies Ltd, Yarnton, Oxfordshire, England.

Chami, F., Chami, N., Bennis, S., Trouillas, J. \& Remmal, A. (2004). J. Antimicrob. Chemother. 54, 909-914.

Chi, N. T. T., Da, T. T., Ha, N. V. \& Dinh, N. H. (2017a). J. Coord. Chem. 70, 1008-1019.

Chi, N. T. T., Da, T. T., Robeyns, K., Van Meervelt, L., Mai, T. T. C. \& Dinh, N. H. (2018). Polyhedron, 151, 330-337.

Chi, N. T. T., Mai, T. T. C., Nhan, N. T. T. \& Da, T. T. (2013). Vietnam J. Chem. 51, 500-504.

Chi, N. T. T., Mai, T. T. C., Thong, P. V., Long, N., My, L. H. \& Van Meervelt, L. (2017b). Acta Cryst. C73, 1030-1037.

Chi, N. T. T., Ngan, N. B. \& Van Meervelt, L. (2014). Acta Cryst. E70, 36-38.

Da, T. T., Hong Hai, L. T., Meervelt, L. V. \& Dinh, N. H. (2015). J. Coord. Chem. 68, 3525-3536.

Dolomanov, O. V., Bourhis, L. J., Gildea, R. J., Howard, J. A. K. \& Puschmann, H. (2009). J. Appl. Cryst. 42, 339-341.

Fang, L., Feng, M., Chen, F., Liu, X., Shen, H., Zhao, J. \& Gou, S. (2016). Bioorg. Med. Chem. 24, 4611-4619.
Ghelman, A. D., Karandasova, E. F. \& Essen, L. N. (1949). Inst. Obsch. Nheorg. Khim. AN SSSR, 24, 68.

Gill, A. O. \& Holley, R. A. (2004). Appl. Environ. Microbiol. 70, 5750-5755.

Johnstone, T. C., Park, G. Y. \& Lippard, S. J. (2014). Anticancer Res. 34, 471-476.

Johnstone, T. C., Suntharalingam, K. \& Lippard, S. J. (2016). Chem. Rev. 116, 3436-3486.

Kato, K., Nishibori, E., Takata, M., Sakata, M., Nakano, T., Uchihira, K., Tsubota, M., Iga, F. \& Takabatake, T. (2002). Acta Cryst. A58, c147.

Labarrios, F., Garduño, L., Vidal, M. D. R., Garcia, R., Salazar, M., Martinez, E., Diaz, F., Chamorro, G. \& Tamariz, J. (1999). J. Pharm. Pharmacol. 51, 1-7.

Li, L., Zhang, J., Ma, L., Zhang, Z., Wang, S., Li, S. \& Zhou, G. (2013). J. Coord. Chem. 66, 638-649.

Liu, F., Zhou, Z., Gou, S., Zhao, J. \& Chen, F. (2014). J. Coord. Chem. 67, 2858-2866.

Luo, X. J., Qin, Q. P., Li, Y. L., Liu, Y. C., Chen, Z. F. \& Liang, H. (2014). Inorg. Chem. Commun. 46, 176-179.

Massoni, M., Clavijo, J. C. T., Colina-Vegas, L., Villarreal, W., Dias, J. S. M., da Silva, G. A. F., Ionta, M., Soares, M., Ellena, J., Dorigueto, A. C., Barbosa, M. I. F. \& Batista, A. A. (2017). Polyhedron, 129, 214-221.

Meng, T., Tang, S. F., Qin, Q. P., Liang, Y. L., Wu, C. X., Wang, C. Y., Yan, H. T., Dong, J. X. \& Liu, Y. C. (2016). Med. Chem. Commun. 7, 1802-1811.

Nakatake, H., Ekimoto, H., Aso, M., Ogawa, A., Yamaguchi, A. \& Suemune, H. (2011). Chem. Pharm. Bull. 59, 710-713.

Pneumatikakis, G. (1984). Inorg. Chim. Acta, 93, 5-11.

Pramod, K., Ansari, S. H. \& Ali, J. (2013). Asian J. Pharm. Anal. 3, 58-61.

Qin, Q. P., Chen, Z. F., Qin, J. L., He, X. V., Li, U. L., Liu, Y. C., Huang, K. B. \& Liang, H. (2015). Eur. J. Med. Chem. 92, 302313.

Romerosa, A., Bergamini, P., Bertolasi, V., Canella, A., Cattabriga, M., Gavioli, R., Mañas, S., Mantovani, N. \& Pellacani, L. (2004). Inorg. Chem. 43, 905-913.

Shahabadi, L. \& Moeini, Z. (2015). J. Coord. Chem. 68, 2871-2885.

Sheldrick, G. M. (2008). Acta Cryst. A64, 112-122.

Sheldrick, G. M. (2015). Acta Cryst. C71, 3-8.

Thong, P. V. \& Chi, N. T. T. (2014). J. Chem. (Vietnam), 52, 381386.

Tragoolpua, Y. \& Jatisatienr, A. (2007). Phytother. Res. 21, 1153-1158. Zhang, J. J., Che, C. M. \& Ott, I. (2015). J. Coord. Chem. 782, 37-41. 


\section{supporting information}

Acta Cryst. (2018). C74, 1732-1743 [https://doi.org/10.1107/S2053229618015978]

\section{Mixed natural arylolefin-quinoline platinum(II) complexes: synthesis, structural characterization and in vitro cytotoxicity studies}

\section{Nguyen Thi Thanh Chi, Pham Van Thong, Truong Thi Cam Mai and Luc Van Meervelt}

\section{Computing details}

For all structures, data collection: CrysAlis PRO (Agilent, 2013); cell refinement: CrysAlis PRO (Agilent, 2013); data reduction: CrysAlis PRO (Agilent, 2013); program(s) used to solve structure: SHELXS97 (Sheldrick, 2008); program(s) used to refine structure: SHELXL2016 (Sheldrick, 2015); molecular graphics: OLEX2 (Dolomanov et al., 2009); software used to prepare material for publication: OLEX2 (Dolomanov et al., 2009).

[ $\eta^{2}$-4-Allyl-2-methoxy-1-(propoxycarbonylmethoxy)benzene]-trans-dichlorido(quinoline- $\kappa \mathrm{N}$ ) platinum(II) (chi29)

\section{Crystal data}

$\left[\mathrm{PtCl}_{2}\left(\mathrm{C}_{15} \mathrm{H}_{20} \mathrm{O}_{4}\right)\left(\mathrm{C}_{9} \mathrm{H}_{7} \mathrm{~N}\right)\right]$

$M_{r}=659.45$

Triclinic, $P \overline{1}$

$a=8.1252(3) \AA$

$b=11.7042(4) \AA$

$c=13.7340(5) \AA$

$\alpha=65.864(4)^{\circ}$

$\beta=84.716(3)^{\circ}$

$\gamma=88.191(3)^{\circ}$

$V=1186.82(9) \AA^{3}$

\section{Data collection}

Agilent SuperNova Dual Source diffractometer with an Eos detector

Radiation source: SuperNova (Mo) X-ray Source

Mirror monochromator

Detector resolution: 15.9631 pixels $\mathrm{mm}^{-1}$

$\omega$ scans

Absorption correction: multi-scan

(CrysAlis PRO; Agilent, 2013)

\section{Refinement}

Refinement on $F^{2}$

Least-squares matrix: full

$R\left[F^{2}>2 \sigma\left(F^{2}\right)\right]=0.036$

$w R\left(F^{2}\right)=0.073$

$S=1.12$

4867 reflections

337 parameters

14 restraints
$Z=2$
$F(000)=644$
$D_{\mathrm{x}}=1.845 \mathrm{Mg} \mathrm{m}^{-3}$

Mo $K \alpha$ radiation, $\lambda=0.71073 \AA$

Cell parameters from 9524 reflections

$\theta=3.1-28.7^{\circ}$

$\mu=6.17 \mathrm{~mm}^{-1}$

$T=100 \mathrm{~K}$

Needle, yellow

$0.35 \times 0.1 \times 0.1 \mathrm{~mm}$

$T_{\min }=0.432, T_{\max }=1.000$

19752 measured reflections

4867 independent reflections

4458 reflections with $I>2 \sigma(I)$

$R_{\text {int }}=0.036$

$\theta_{\text {max }}=26.4^{\circ}, \theta_{\min }=2.9^{\circ}$

$h=-10 \rightarrow 10$

$k=-14 \rightarrow 14$

$l=-16 \rightarrow 17$

Hydrogen site location: inferred from neighbouring sites

$\mathrm{H}$-atom parameters constrained

$w=1 /\left[\sigma^{2}\left(F_{\mathrm{o}}{ }^{2}\right)+(0.0079 P)^{2}+5.6087 P\right]$

where $P=\left(F_{\mathrm{o}}^{2}+2 F_{\mathrm{c}}^{2}\right) / 3$

$(\Delta / \sigma)_{\max }<0.001$

$\Delta \rho_{\max }=3.21 \mathrm{e} \AA^{-3}$

$\Delta \rho_{\min }=-1.79 \mathrm{e} \AA^{-3}$ 


\section{Special details}

Geometry. All esds (except the esd in the dihedral angle between two 1.s. planes) are estimated using the full covariance matrix. The cell esds are taken into account individually in the estimation of esds in distances, angles and torsion angles; correlations between esds in cell parameters are only used when they are defined by crystal symmetry. An approximate (isotropic) treatment of cell esds is used for estimating esds involving l.s. planes.

Fractional atomic coordinates and isotropic or equivalent isotropic displacement parameters $\left(\AA^{2}\right)$

\begin{tabular}{|c|c|c|c|c|c|}
\hline & $x$ & $y$ & $z$ & $U_{\text {iso }} * / U_{\text {eq }}$ & Occ. $(<1)$ \\
\hline Pt1A & 0.7798 & $1.14396(15)$ & $0.16089(7)$ & $0.0218(2)$ & $0.656(8)$ \\
\hline Pt1B & $0.8263(6)$ & $1.1211(3)$ & $0.15616(15)$ & $0.0265(4)$ & $0.344(8)$ \\
\hline $\mathrm{Cl} 2 \mathrm{~A}$ & $0.5445(3)$ & $1.2493(3)$ & $0.1821(2)$ & $0.0266(6)$ & $0.656(8)$ \\
\hline $\mathrm{Cl} 2 \mathrm{~B}$ & $0.5661(6)$ & $1.1993(8)$ & 0.1688 & $0.0363(13)$ & $0.344(8)$ \\
\hline $\mathrm{Cl} 3 \mathrm{~A}$ & $1.0244(5)$ & $1.0451(3)$ & $0.1445(2)$ & $0.0277(6)$ & $0.656(8)$ \\
\hline $\mathrm{Cl} 3 \mathrm{~B}$ & $1.0943(11)$ & $1.0535(7)$ & $0.1458(5)$ & $0.0387(15)$ & $0.344(8)$ \\
\hline N4 & $0.8817(5)$ & $1.1787(4)$ & 0.2779 & $0.0304(9)$ & \\
\hline C5 & $0.9845(6)$ & $1.2744(4)$ & 0.2488 (4) & $0.0270(10)$ & \\
\hline H5 & 1.017631 & 1.317137 & 0.174624 & $0.032 *$ & \\
\hline C6 & $1.0480(6)$ & $1.3173(5)$ & $0.3183(4)$ & $0.0291(11)$ & \\
\hline H6 & 1.121358 & 1.387069 & 0.292850 & $0.035^{*}$ & \\
\hline $\mathrm{C} 7$ & $0.9996(6)$ & $1.2538(5)$ & $0.4266(4)$ & $0.0331(12)$ & \\
\hline $\mathrm{H} 7$ & 1.038101 & 1.280591 & 0.477129 & $0.040^{*}$ & \\
\hline $\mathrm{C} 8$ & $0.8923(5)$ & $1.1485(4)$ & $0.4616(4)$ & $0.0220(9)$ & \\
\hline C9 & $0.8457(6)$ & $1.0762(5)$ & $0.5707(4)$ & $0.0329(12)$ & \\
\hline H9 & 0.886544 & 1.098149 & 0.623483 & $0.039 *$ & \\
\hline $\mathrm{C} 10$ & $0.7439(6)$ & $0.9763(5)$ & $0.6016(4)$ & $0.0360(12)$ & \\
\hline H10 & 0.711827 & 0.929103 & 0.675353 & $0.043^{*}$ & \\
\hline C11 & $0.6863(6)$ & $0.9429(5)$ & $0.5240(4)$ & $0.0292(11)$ & \\
\hline H11 & 0.614478 & 0.872448 & 0.546956 & $0.035^{*}$ & \\
\hline $\mathrm{C} 12$ & $0.7277(5)$ & $1.0061(4)$ & $0.4171(4)$ & $0.0263(10)$ & \\
\hline $\mathrm{H} 12$ & 0.687704 & 0.980387 & 0.366333 & $0.032 *$ & \\
\hline C13 & $0.8345(6)$ & $1.1133(5)$ & $0.3841(4)$ & $0.0266(10)$ & \\
\hline $\mathrm{C} 14 \mathrm{~A}$ & $0.7271(13)$ & $1.1640(9)$ & $0.0050(8)$ & $0.027(2)$ & $0.656(8)$ \\
\hline H14A & 0.818330 & 1.150443 & -0.037382 & $0.033^{*}$ & $0.656(8)$ \\
\hline H14B & 0.699529 & 1.246656 & -0.002897 & $0.033^{*}$ & $0.656(8)$ \\
\hline C14B & $0.783(3)$ & $1.1440(12)$ & $-0.0069(16)$ & $0.025(5)$ & $0.344(8)$ \\
\hline $\mathrm{H} 14 \mathrm{C}$ & 0.682405 & 1.183980 & -0.033108 & $0.030 *$ & $0.344(8)$ \\
\hline H14D & 0.883222 & 1.190307 & -0.027753 & $0.030^{*}$ & $0.344(8)$ \\
\hline C15A & $0.6335(8)$ & $1.0627(6)$ & $0.0787(5)$ & $0.0219(17)$ & $0.656(8)$ \\
\hline $\mathrm{H} 15 \mathrm{~A}$ & 0.514099 & 1.084817 & 0.083641 & $0.026^{*}$ & $0.656(8)$ \\
\hline C15B & $0.7818(15)$ & $1.0182(12)$ & $0.0618(10)$ & $0.030(4)$ & $0.344(8)$ \\
\hline H15B & 0.885328 & 0.976909 & 0.047701 & $0.036^{*}$ & $0.344(8)$ \\
\hline C16 & $0.6538(8)$ & $0.9333(5)$ & $0.1026(4)$ & $0.0433(15)$ & \\
\hline H16A & 0.764296 & 0.922215 & 0.070763 & $0.052 *$ & $0.656(8)$ \\
\hline H16B & 0.571023 & 0.909066 & 0.065743 & $0.052 *$ & $0.656(8)$ \\
\hline $\mathrm{H} 16 \mathrm{C}$ & 0.658121 & 0.882998 & 0.059340 & $0.052 *$ & $0.344(8)$ \\
\hline H16D & 0.549857 & 0.981538 & 0.089099 & $0.052^{*}$ & $0.344(8)$ \\
\hline C17 & $0.6386(7)$ & $0.8423(5)$ & $0.2189(4)$ & $0.0303(11)$ & \\
\hline
\end{tabular}




$\begin{array}{lllll}\text { C18 } & 0.7735(6) & 0.7702(4) & 0.2630(4) & 0.0263(10) \\ \text { H18 } & 0.873913 & 0.778617 & 0.219332 & 0.032^{*} \\ \text { C19 } & 0.7647(6) & 0.6864(4) & 0.3692(4) & 0.0247(10) \\ \text { C20 } & 0.6174(6) & 0.6750(4) & 0.4348(4) & 0.0259(10) \\ \text { C21 } & 0.4818(6) & 0.7449(5) & 0.3906(4) & 0.0306(11) \\ \text { H21 } & 0.380501 & 0.735833 & 0.433631 & 0.037^{*} \\ \text { C22 } & 0.4930(7) & 0.8286(5) & 0.2830(4) & 0.0347(12) \\ \text { H22 } & 0.399386 & 0.876730 & 0.253642 & 0.042^{*} \\ \text { O23 } & 0.8917(4) & 0.6111(3) & 0.4178(3) & 0.0280(7) \\ \text { C24 } & 1.0443(6) & 0.6212(5) & 0.3527(4) & 0.0331(12) \\ \text { H24A } & 1.024473 & 0.600999 & 0.292203 & 0.050^{*} \\ \text { H24B } & 1.124805 & 0.562539 & 0.395878 & 0.050^{*} \\ \text { H24C } & 1.087552 & 0.706805 & 0.325834 & 0.050^{*} \\ \text { O25 } & 0.6212(4) & 0.5923(3) & 0.5400(3) & 0.0294(8) \\ \text { C26 } & 0.4797(6) & 0.5859(5) & 0.6092(4) & 0.0271(10) \\ \text { H26A } & 0.385482 & 0.550928 & 0.589158 & 0.032^{*} \\ \text { H26B } & 0.449664 & 0.670725 & 0.604002 & 0.032^{*} \\ \text { C27 } & 0.5177(6) & 0.5029(4) & 0.7221(4) & 0.0269(10) \\ \text { O28 } & 0.6508(4) & 0.4610(3) & 0.7501(3) & 0.0340(8) \\ \text { O29 } & 0.3804(4) & 0.4862(3) & 0.7874(3) & 0.0296(8) \\ \text { C30 } & 0.3997(6) & 0.4167(5) & 0.9005(4) & 0.0313(11) \\ \text { H30A } & 0.497099 & 0.447884 & 0.920848 & 0.038^{*} \\ \text { H30B } & 0.415443 & 0.326622 & 0.917035 & 0.038^{*} \\ \text { C31 } & 0.2440(6) & 0.4356(5) & 0.9611(4) & 0.0334(12) \\ \text { H31A } & 0.229895 & 0.526173 & 0.943080 & 0.040^{*} \\ \text { H31B } & 0.255733 & 0.392959 & 1.038969 & 0.040^{*} \\ \text { C32 } & 0.0907(6) & 0.3855(5) & 0.9357(4) & 0.0331(12) \\ \text { H32A } & 0.076437 & 0.429307 & 0.859105 & 0.050^{*} \\ \text { H32B } & -0.006417 & 0.399117 & 0.977384 & 0.050^{*} \\ \text { H32C } & 0.103443 & 0.295626 & 0.954158 & 0.050^{*}\end{array}$

Atomic displacement parameters $\left(\AA^{2}\right)$

\begin{tabular}{lllllll}
\hline & $U^{11}$ & $U^{22}$ & $U^{33}$ & $U^{12}$ & $U^{13}$ & $U^{23}$ \\
\hline Pt1A & $0.0224(5)$ & $0.0218(4)$ & $0.02258(19)$ & $0.0050(3)$ & $-0.0097(2)$ & $-0.00915(19)$ \\
Pt1B & $0.0303(10)$ & $0.0276(6)$ & $0.0235(4)$ & $0.0092(6)$ & $-0.0126(5)$ & $-0.0109(4)$ \\
C12A & $0.0234(10)$ & $0.0243(13)$ & $0.0346(11)$ & $0.0062(9)$ & $-0.0088(8)$ & $-0.0136(10)$ \\
C12B & $0.034(2)$ & $0.040(3)$ & $0.035(2)$ & $0.010(2)$ & $-0.0070(17)$ & $-0.015(2)$ \\
C13A & $0.0237(15)$ & $0.0344(12)$ & $0.0284(11)$ & $0.0061(13)$ & $-0.0057(12)$ & $-0.0161(9)$ \\
C13B & $0.034(4)$ & $0.053(3)$ & $0.036(2)$ & $0.012(3)$ & $-0.010(3)$ & $-0.024(2)$ \\
N4 & $0.027(2)$ & $0.033(2)$ & $0.031(2)$ & $0.0013(18)$ & $-0.0066(18)$ & $-0.0131(19)$ \\
C5 & $0.025(2)$ & $0.025(3)$ & $0.028(2)$ & $-0.004(2)$ & $-0.001(2)$ & $-0.008(2)$ \\
C6 & $0.027(3)$ & $0.026(3)$ & $0.038(3)$ & $0.003(2)$ & $-0.008(2)$ & $-0.016(2)$ \\
C7 & $0.028(3)$ & $0.036(3)$ & $0.044(3)$ & $0.009(2)$ & $-0.009(2)$ & $-0.024(3)$ \\
C8 & $0.016(2)$ & $0.026(2)$ & $0.026(2)$ & $0.0102(18)$ & $-0.0037(18)$ & $-0.014(2)$ \\
C9 & $0.030(3)$ & $0.038(3)$ & $0.026(3)$ & $0.014(2)$ & $0.000(2)$ & $-0.011(2)$ \\
C10 & $0.031(3)$ & $0.038(3)$ & $0.032(3)$ & $0.013(2)$ & $0.003(2)$ & $-0.009(2)$ \\
C11 & $0.019(2)$ & $0.027(3)$ & $0.036(3)$ & $0.006(2)$ & $-0.002(2)$ & $-0.008(2)$
\end{tabular}




$\begin{array}{lllllll}\text { C12 } & 0.019(2) & 0.027(3) & 0.029(2) & 0.0057(19) & -0.0062(19) & -0.007(2) \\ \text { C13 } & 0.021(2) & 0.031(3) & 0.027(2) & 0.013(2) & -0.0087(19) & -0.010(2) \\ \text { C14A } & 0.035(6) & 0.035(5) & 0.015(4) & -0.001(4) & 0.000(4) & -0.013(4) \\ \text { C14B } & 0.028(8) & 0.032(8) & 0.013(7) & -0.010(6) & 0.001(6) & -0.007(6) \\ \text { C15A } & 0.022(4) & 0.024(4) & 0.022(3) & 0.000(3) & -0.011(3) & -0.009(3) \\ \text { C15B } & 0.035(7) & 0.038(7) & 0.022(6) & 0.003(5) & -0.008(5) & -0.017(5) \\ \text { C16 } & 0.078(4) & 0.025(3) & 0.027(3) & -0.005(3) & -0.020(3) & -0.006(2) \\ \text { C17 } & 0.043(3) & 0.021(3) & 0.028(3) & -0.003(2) & -0.011(2) & -0.008(2) \\ \text { C18 } & 0.033(3) & 0.021(2) & 0.024(2) & 0.000(2) & -0.002(2) & -0.010(2) \\ \text { C19 } & 0.027(2) & 0.021(2) & 0.027(2) & 0.0047(19) & -0.0043(19) & -0.010(2) \\ \text { C20 } & 0.023(2) & 0.021(2) & 0.030(3) & 0.0009(19) & 0.0007(19) & -0.008(2) \\ \text { C21 } & 0.024(2) & 0.023(3) & 0.041(3) & 0.004(2) & -0.003(2) & -0.009(2) \\ \text { C22 } & 0.035(3) & 0.026(3) & 0.045(3) & 0.008(2) & -0.017(2) & -0.014(2) \\ \text { O23 } & 0.0241(17) & 0.0315(19) & 0.0235(17) & 0.0103(14) & 0.0027(13) & -0.0079(15) \\ \text { C24 } & 0.026(3) & 0.040(3) & 0.028(3) & 0.006(2) & 0.006(2) & -0.011(2) \\ \text { O25 } & 0.0275(18) & 0.0244(18) & 0.0228(17) & 0.0054(14) & 0.0111(14) & 0.0009(14) \\ \text { C26 } & 0.019(2) & 0.024(3) & 0.034(3) & 0.0021(19) & 0.0087(19) & -0.010(2) \\ \text { C27 } & 0.027(3) & 0.019(2) & 0.033(3) & -0.004(2) & 0.007(2) & -0.010(2) \\ \text { O28 } & 0.0217(18) & 0.036(2) & 0.035(2) & 0.0053(15) & 0.0056(15) & -0.0076(16) \\ \text { O29 } & 0.0236(17) & 0.037(2) & 0.0259(17) & 0.0019(15) & 0.0049(14) & -0.0126(15) \\ \text { C30 } & 0.024(2) & 0.037(3) & 0.029(3) & 0.005(2) & 0.001(2) & -0.011(2) \\ \text { C31 } & 0.025(3) & 0.044(3) & 0.030(3) & 0.001(2) & 0.006(2) & -0.015(2) \\ \text { C32 } & 0.031(3) & 0.034(3) & 0.032(3) & 0.001(2) & 0.005(2) & -0.013(2) \\ & & & & & \end{array}$

Geometric parameters $\left(\AA,{ }^{\circ}\right)$

\begin{tabular}{llll}
\hline PT1Aa-Cl2A & $2.303(2)$ & $\mathrm{C} 12-\mathrm{C} 13$ & $1.437(7)$ \\
PT1Bb-Cl2B & $2.298(5)$ & $\mathrm{C} 16-\mathrm{H} 16 \mathrm{~A}$ & 0.9900 \\
PT1Aa-Cl3A & $2.307(3)$ & $\mathrm{C} 16-\mathrm{H} 16 \mathrm{~B}$ & 0.9900 \\
PT1Bb-Cl3B & $2.305(6)$ & $\mathrm{C} 16-\mathrm{H} 16 \mathrm{C}$ & 0.9900 \\
PT1Aa-N4 & $2.058(4)$ & $\mathrm{C} 16-\mathrm{H} 16 \mathrm{D}$ & 0.9900 \\
PT1Bb-N4 & $2.129(5)$ & $\mathrm{C} 16-\mathrm{C} 17$ & $1.510(7)$ \\
PT1Aa-C14A & $2.139(11)$ & $\mathrm{C} 17-\mathrm{C} 18$ & $1.388(7)$ \\
C14Aa-H14A & 0.9500 & $\mathrm{C} 17-\mathrm{C} 22$ & $1.381(8)$ \\
C14Aa-H14B & 0.9500 & $\mathrm{C} 18-\mathrm{H} 18$ & 0.9500 \\
PT1Bb-C14B & $2.20(2)$ & $\mathrm{C} 18-\mathrm{C} 19$ & $1.382(6)$ \\
C14Bb-H14C & 0.9500 & $\mathrm{C} 19-\mathrm{C} 20$ & $1.406(7)$ \\
C14Bb-H14D & 0.9500 & $\mathrm{C} 19-\mathrm{O} 23$ & $1.369(5)$ \\
C14Aa-C15A & $1.394(9)$ & $\mathrm{C} 20-\mathrm{C} 21$ & $1.382(7)$ \\
PT1Aa-C15A & $2.188(6)$ & $\mathrm{C} 20-\mathrm{O} 25$ & $1.374(6)$ \\
C15Aa-H15A & 1.0000 & $\mathrm{C} 21-\mathrm{H} 21$ & 0.9500 \\
PT1Bb-C15B & $2.157(13)$ & $\mathrm{C} 21-\mathrm{C} 22$ & $1.396(7)$ \\
C14Bb-C15B & $1.386(11)$ & $\mathrm{C} 22-\mathrm{H} 22$ & 0.9500 \\
C15Bb-H15B & 1.0000 & $\mathrm{O} 23-\mathrm{C} 24$ & $1.438(5)$ \\
C15Bb-C16 & $1.373(10)$ & $\mathrm{C} 24-\mathrm{H} 24 \mathrm{~A}$ & 0.9800 \\
C15Aa-C16 & $1.420(8)$ & $\mathrm{C} 24-\mathrm{H} 24 \mathrm{~B}$ & 0.9800 \\
N4-C5 & $1.320(6)$ & $\mathrm{C} 24-\mathrm{H} 24 \mathrm{C}$ & 0.9800 \\
N4-C13 & $1.365(6)$ & $\mathrm{O} 25-\mathrm{C} 26$ & $1.406(5)$
\end{tabular}




\begin{tabular}{|c|c|c|c|}
\hline $\mathrm{C} 5-\mathrm{H} 5$ & 0.9500 & $\mathrm{C} 26-\mathrm{H} 26 \mathrm{~A}$ & 0.9900 \\
\hline $\mathrm{C} 5-\mathrm{C} 6$ & $1.389(7)$ & $\mathrm{C} 26-\mathrm{H} 26 \mathrm{~B}$ & 0.9900 \\
\hline $\mathrm{C} 6-\mathrm{H} 6$ & 0.9500 & $\mathrm{C} 26-\mathrm{C} 27$ & $1.510(7)$ \\
\hline $\mathrm{C} 6-\mathrm{C} 7$ & $1.388(7)$ & $\mathrm{C} 27-\mathrm{O} 28$ & $1.203(6)$ \\
\hline $\mathrm{C} 7-\mathrm{H} 7$ & 0.9500 & $\mathrm{C} 27-\mathrm{O} 29$ & $1.332(6)$ \\
\hline $\mathrm{C} 7-\mathrm{C} 8$ & $1.419(7)$ & $\mathrm{O} 29-\mathrm{C} 30$ & $1.450(6)$ \\
\hline $\mathrm{C} 8-\mathrm{C} 9$ & $1.409(7)$ & $\mathrm{C} 30-\mathrm{H} 30 \mathrm{~A}$ & 0.9900 \\
\hline $\mathrm{C} 8-\mathrm{C} 13$ & $1.408(6)$ & $\mathrm{C} 30-\mathrm{H} 30 \mathrm{~B}$ & 0.9900 \\
\hline C9-H9 & 0.9500 & $\mathrm{C} 30-\mathrm{C} 31$ & $1.511(6)$ \\
\hline $\mathrm{C} 9-\mathrm{C} 10$ & $1.350(8)$ & $\mathrm{C} 31-\mathrm{H} 31 \mathrm{~A}$ & 0.9900 \\
\hline $\mathrm{C} 10-\mathrm{H} 10$ & 0.9500 & $\mathrm{C} 31-\mathrm{H} 31 \mathrm{~B}$ & 0.9900 \\
\hline $\mathrm{C} 10-\mathrm{C} 11$ & $1.398(7)$ & $\mathrm{C} 31-\mathrm{C} 32$ & $1.521(7)$ \\
\hline $\mathrm{C} 11-\mathrm{H} 11$ & 0.9500 & $\mathrm{C} 32-\mathrm{H} 32 \mathrm{~A}$ & 0.9800 \\
\hline $\mathrm{C} 11-\mathrm{C} 12$ & $1.361(7)$ & $\mathrm{C} 32-\mathrm{H} 32 \mathrm{~B}$ & 0.9800 \\
\hline $\mathrm{C} 12-\mathrm{H} 12$ & 0.9500 & $\mathrm{C} 32-\mathrm{H} 32 \mathrm{C}$ & 0.9800 \\
\hline $\mathrm{C} 14 \mathrm{Aa}-\mathrm{C} 15 \mathrm{Aa}-\mathrm{Pt} 1 \mathrm{~A}$ & $69.3(6)$ & $\mathrm{C} 15 \mathrm{Bb}-\mathrm{C} 16-\mathrm{H} 16 \mathrm{D}$ & 107.1 \\
\hline $\mathrm{C} 15 \mathrm{Aa}-\mathrm{C} 14 \mathrm{Aa}-\mathrm{Pt} 1 \mathrm{~A}$ & $73.1(5)$ & $\mathrm{H} 16 \mathrm{Cb}-\mathrm{C} 16-\mathrm{H} 16 \mathrm{D}$ & 106.8 \\
\hline $\mathrm{C} 5-\mathrm{N} 4-\mathrm{Pt} 1 \mathrm{~A}$ & $118.8(3)$ & $\mathrm{C} 15 \mathrm{Aa}-\mathrm{C} 16-\mathrm{C} 17$ & $117.9(5)$ \\
\hline $\mathrm{C} 5-\mathrm{N} 4-\mathrm{Pt} 1 \mathrm{~B}$ & $116.7(3)$ & $\mathrm{C} 15 \mathrm{Bb}-\mathrm{C} 16-\mathrm{C} 17$ & $121.0(7)$ \\
\hline $\mathrm{C} 5-\mathrm{N} 4-\mathrm{C} 13$ & $119.0(4)$ & $\mathrm{C} 18-\mathrm{C} 17-\mathrm{C} 16$ & $119.7(5)$ \\
\hline $\mathrm{C} 13-\mathrm{N} 4-\mathrm{Pt} 1 \mathrm{~A}$ & $121.9(3)$ & $\mathrm{C} 22-\mathrm{C} 17-\mathrm{C} 16$ & $121.6(5)$ \\
\hline $\mathrm{C} 13-\mathrm{N} 4-\mathrm{Pt} 1 \mathrm{~B}$ & $123.7(3)$ & $\mathrm{C} 22-\mathrm{C} 17-\mathrm{C} 18$ & $118.7(5)$ \\
\hline $\mathrm{N} 4-\mathrm{C} 5-\mathrm{H} 5$ & 117.5 & $\mathrm{C} 17-\mathrm{C} 18-\mathrm{H} 18$ & 119.3 \\
\hline $\mathrm{C} 14 \mathrm{Bb}-\mathrm{C} 15 \mathrm{Bb}-\mathrm{Pt} 1 \mathrm{~B}$ & $73.4(11)$ & $\mathrm{C} 19-\mathrm{C} 18-\mathrm{C} 17$ & $121.4(5)$ \\
\hline $\mathrm{C} 15 \mathrm{Bb}-\mathrm{C} 14 \mathrm{Bb}-\mathrm{Pt} 1 \mathrm{~B}$ & $69.6(10)$ & $\mathrm{C} 19-\mathrm{C} 18-\mathrm{H} 18$ & 119.3 \\
\hline $\mathrm{C} 15 \mathrm{Aa}-\mathrm{PT} 1 \mathrm{Aa}-\mathrm{Cl} 2 \mathrm{~A}$ & $87.0(2)$ & $\mathrm{C} 18-\mathrm{C} 19-\mathrm{C} 20$ & $119.6(4)$ \\
\hline $\mathrm{C} 14 \mathrm{Aa}-\mathrm{PT} 1 \mathrm{Aa}-\mathrm{Cl} 2 \mathrm{~A}$ & $92.7(3)$ & $\mathrm{O} 23-\mathrm{C} 19-\mathrm{C} 18$ & $124.7(4)$ \\
\hline $\mathrm{C} 15 \mathrm{Bb}-\mathrm{PT} 1 \mathrm{Bb}-\mathrm{Cl} 2 \mathrm{~B}$ & $99.5(5)$ & $\mathrm{O} 23-\mathrm{C} 19-\mathrm{C} 20$ & $115.8(4)$ \\
\hline $\mathrm{C} 14 \mathrm{Bb}-\mathrm{PT} 1 \mathrm{Bb}-\mathrm{Cl} 2 \mathrm{~B}$ & $87.8(5)$ & $\mathrm{C} 21-\mathrm{C} 20-\mathrm{C} 19$ & $119.2(4)$ \\
\hline $\mathrm{C} 15 \mathrm{Aa}-\mathrm{PT} 1 \mathrm{Aa}-\mathrm{Cl} 3 \mathrm{~A}$ & $96.6(2)$ & $\mathrm{O} 25-\mathrm{C} 20-\mathrm{C} 19$ & $115.7(4)$ \\
\hline $\mathrm{CL} 2 \mathrm{Aa}-\mathrm{PT} 1 \mathrm{Aa}-\mathrm{Cl} 3 \mathrm{~A}$ & $176.37(10)$ & $\mathrm{O} 25-\mathrm{C} 20-\mathrm{C} 21$ & $125.1(4)$ \\
\hline $\mathrm{C} 14 \mathrm{Aa}-\mathrm{PT} 1 \mathrm{Aa}-\mathrm{Cl3A}$ & $90.0(3)$ & $\mathrm{C} 20-\mathrm{C} 21-\mathrm{H} 21$ & 119.9 \\
\hline $\mathrm{CL} 2 \mathrm{Bb}-\mathrm{PT} 1 \mathrm{Bb}-\mathrm{Cl} 3 \mathrm{~B}$ & $176.1(2)$ & $\mathrm{C} 20-\mathrm{C} 21-\mathrm{C} 22$ & $120.3(5)$ \\
\hline $\mathrm{C} 14 \mathrm{Bb}-\mathrm{PT} 1 \mathrm{Bb}-\mathrm{Cl} 3 \mathrm{~B}$ & $94.2(5)$ & $\mathrm{C} 22-\mathrm{C} 21-\mathrm{H} 21$ & 119.9 \\
\hline $\mathrm{C} 15 \mathrm{Bb}-\mathrm{PT} 1 \mathrm{Bb}-\mathrm{Cl} 3 \mathrm{~B}$ & $84.1(5)$ & $\mathrm{C} 17-\mathrm{C} 22-\mathrm{C} 21$ & $120.8(5)$ \\
\hline $\mathrm{C} 15 \mathrm{Aa}-\mathrm{C} 14 \mathrm{Aa}-\mathrm{H} 14 \mathrm{~A}$ & 120.0 & $\mathrm{C} 17-\mathrm{C} 22-\mathrm{H} 22$ & 119.6 \\
\hline PT1Aa $-\mathrm{C} 14 \mathrm{Aa}-\mathrm{H} 14 \mathrm{~A}$ & 115.0 & $\mathrm{C} 21-\mathrm{C} 22-\mathrm{H} 22$ & 119.6 \\
\hline $\mathrm{H} 14 \mathrm{Aa}-\mathrm{C} 14 \mathrm{Aa}-\mathrm{H} 14 \mathrm{~B}$ & 120.0 & $\mathrm{C} 19-\mathrm{O} 23-\mathrm{C} 24$ & $117.0(4)$ \\
\hline $\mathrm{C} 15 \mathrm{Aa}-\mathrm{C} 14 \mathrm{Aa}-\mathrm{H} 14 \mathrm{~B}$ & 120.0 & $\mathrm{O} 23-\mathrm{C} 24-\mathrm{H} 24 \mathrm{~A}$ & 109.5 \\
\hline PT1Aa-C14Aa-H14B & 82.4 & $\mathrm{~N} 4-\mathrm{PT} 1 \mathrm{Aa}-\mathrm{Cl} 2 \mathrm{~A}$ & $90.11(14)$ \\
\hline $\mathrm{C} 15 \mathrm{Bb}-\mathrm{PT} 1 \mathrm{Bb}-\mathrm{C} 14 \mathrm{~B}$ & $37.0(4)$ & $\mathrm{N} 4-\mathrm{PT} 1 \mathrm{Bb}-\mathrm{Cl} 2 \mathrm{~B}$ & $86.73(18)$ \\
\hline $\mathrm{C} 15 \mathrm{Bb}-\mathrm{C} 14 \mathrm{Bb}-\mathrm{H} 14 \mathrm{C}$ & 120.0 & $\mathrm{~N} 4-\mathrm{PT} 1 \mathrm{Aa}-\mathrm{Cl} 3 \mathrm{~A}$ & $86.51(14)$ \\
\hline $\mathrm{PT} 1 \mathrm{Bb}-\mathrm{C} 14 \mathrm{Bb}-\mathrm{H} 14 \mathrm{C}$ & 116.1 & $\mathrm{~N} 4-\mathrm{PT} 1 \mathrm{Bb}-\mathrm{Cl} 3 \mathrm{~B}$ & $90.1(2)$ \\
\hline $\mathrm{PT} 1 \mathrm{Bb}-\mathrm{C} 14 \mathrm{Bb}-\mathrm{H} 14 \mathrm{D}$ & 84.8 & $\mathrm{~N} 4-\mathrm{PT} 1 \mathrm{Aa}-\mathrm{C} 14 \mathrm{~A}$ & $159.7(3)$ \\
\hline $\mathrm{C} 15 \mathrm{Bb}-\mathrm{C} 14 \mathrm{Bb}-\mathrm{H} 14 \mathrm{D}$ & 120.0 & $\mathrm{~N} 4-\mathrm{PT} 1 \mathrm{Bb}-\mathrm{C} 14 \mathrm{~B}$ & $156.6(4)$ \\
\hline $\mathrm{N} 4-\mathrm{C} 5-\mathrm{C} 6$ & $125.1(5)$ & $\mathrm{N} 4-\mathrm{PT} 1 \mathrm{Aa}-\mathrm{C} 15 \mathrm{~A}$ & $162.7(2)$ \\
\hline $\mathrm{C} 6-\mathrm{C} 5-\mathrm{H} 5$ & 117.5 & $\mathrm{~N} 4-\mathrm{PT} 1 \mathrm{Bb}-\mathrm{C} 15 \mathrm{~B}$ & $166.1(4)$ \\
\hline
\end{tabular}




\begin{tabular}{|c|c|c|c|}
\hline $\mathrm{C} 5-\mathrm{C} 6-\mathrm{H} 6$ & 121.5 & $\mathrm{C} 16-\mathrm{C} 15 \mathrm{Aa}-\mathrm{Pt} 1 \mathrm{~A}$ & $117.7(4)$ \\
\hline $\mathrm{C} 7-\mathrm{C} 6-\mathrm{C} 5$ & $117.0(5)$ & $\mathrm{C} 16-\mathrm{C} 15 \mathrm{Bb}-\mathrm{Pt} 1 \mathrm{~B}$ & $115.1(8)$ \\
\hline $\mathrm{C} 7-\mathrm{C} 6-\mathrm{H} 6$ & 121.5 & $\mathrm{C} 16-\mathrm{C} 15 \mathrm{Bb}-\mathrm{C} 14 \mathrm{~B}$ & $130.5(14)$ \\
\hline $\mathrm{C} 6-\mathrm{C} 7-\mathrm{H} 7$ & 120.1 & $\mathrm{C} 16-\mathrm{C} 15 \mathrm{Aa}-\mathrm{H} 15 \mathrm{~A}$ & 111.4 \\
\hline $\mathrm{C} 6-\mathrm{C} 7-\mathrm{C} 8$ & $119.7(5)$ & $\mathrm{C} 16-\mathrm{C} 15 \mathrm{Bb}-\mathrm{H} 15 \mathrm{~B}$ & 110.6 \\
\hline $\mathrm{C} 8-\mathrm{C} 7-\mathrm{H} 7$ & 120.1 & $\mathrm{O} 23-\mathrm{C} 24-\mathrm{H} 24 \mathrm{~B}$ & 109.5 \\
\hline $\mathrm{C} 9-\mathrm{C} 8-\mathrm{C} 7$ & $122.4(5)$ & $\mathrm{O} 23-\mathrm{C} 24-\mathrm{H} 24 \mathrm{C}$ & 109.5 \\
\hline $\mathrm{C} 13-\mathrm{C} 8-\mathrm{C} 7$ & $118.5(4)$ & $\mathrm{H} 24 \mathrm{~A}-\mathrm{C} 24-\mathrm{H} 24 \mathrm{~B}$ & 109.5 \\
\hline $\mathrm{C} 13-\mathrm{C} 8-\mathrm{C} 9$ & $119.0(5)$ & $\mathrm{H} 24 \mathrm{~A}-\mathrm{C} 24-\mathrm{H} 24 \mathrm{C}$ & 109.5 \\
\hline $\mathrm{C} 8-\mathrm{C} 9-\mathrm{H} 9$ & 119.5 & $\mathrm{H} 24 \mathrm{~B}-\mathrm{C} 24-\mathrm{H} 24 \mathrm{C}$ & 109.5 \\
\hline $\mathrm{C} 10-\mathrm{C} 9-\mathrm{C} 8$ & $121.1(5)$ & $\mathrm{C} 20-\mathrm{O} 25-\mathrm{C} 26$ & $116.9(4)$ \\
\hline $\mathrm{C} 10-\mathrm{C} 9-\mathrm{H} 9$ & 119.5 & $\mathrm{O} 25-\mathrm{C} 26-\mathrm{H} 26 \mathrm{~A}$ & 110.1 \\
\hline $\mathrm{C} 9-\mathrm{C} 10-\mathrm{H} 10$ & 120.3 & $\mathrm{O} 25-\mathrm{C} 26-\mathrm{H} 26 \mathrm{~B}$ & 110.1 \\
\hline $\mathrm{C} 9-\mathrm{C} 10-\mathrm{C} 11$ & $119.4(5)$ & $\mathrm{O} 25-\mathrm{C} 26-\mathrm{C} 27$ & $108.2(4)$ \\
\hline $\mathrm{C} 11-\mathrm{C} 10-\mathrm{H} 10$ & 120.3 & $\mathrm{H} 26 \mathrm{~A}-\mathrm{C} 26-\mathrm{H} 26 \mathrm{~B}$ & 108.4 \\
\hline $\mathrm{C} 10-\mathrm{C} 11-\mathrm{H} 11$ & 118.4 & $\mathrm{C} 27-\mathrm{C} 26-\mathrm{H} 26 \mathrm{~A}$ & 110.1 \\
\hline $\mathrm{C} 12-\mathrm{C} 11-\mathrm{C} 10$ & $123.3(5)$ & $\mathrm{C} 27-\mathrm{C} 26-\mathrm{H} 26 \mathrm{~B}$ & 110.1 \\
\hline $\mathrm{C} 12-\mathrm{C} 11-\mathrm{H} 11$ & 118.4 & $\mathrm{O} 28-\mathrm{C} 27-\mathrm{C} 26$ & $126.1(4)$ \\
\hline $\mathrm{C} 11-\mathrm{C} 12-\mathrm{H} 12$ & 121.3 & $\mathrm{O} 28-\mathrm{C} 27-\mathrm{O} 29$ & $124.9(5)$ \\
\hline $\mathrm{C} 11-\mathrm{C} 12-\mathrm{C} 13$ & $117.4(5)$ & $\mathrm{O} 29-\mathrm{C} 27-\mathrm{C} 26$ & $109.0(4)$ \\
\hline $\mathrm{C} 13-\mathrm{C} 12-\mathrm{H} 12$ & 121.3 & $\mathrm{C} 27-\mathrm{O} 29-\mathrm{C} 30$ & $115.7(4)$ \\
\hline $\mathrm{N} 4-\mathrm{C} 13-\mathrm{C} 8$ & $120.6(5)$ & $\mathrm{O} 29-\mathrm{C} 30-\mathrm{H} 30 \mathrm{~A}$ & 110.3 \\
\hline $\mathrm{N} 4-\mathrm{C} 13-\mathrm{C} 12$ & $119.5(4)$ & $\mathrm{O} 29-\mathrm{C} 30-\mathrm{H} 30 \mathrm{~B}$ & 110.3 \\
\hline $\mathrm{C} 8-\mathrm{C} 13-\mathrm{C} 12$ & $119.9(4)$ & $\mathrm{O} 29-\mathrm{C} 30-\mathrm{C} 31$ & $107.1(4)$ \\
\hline $\mathrm{C} 17-\mathrm{C} 16-\mathrm{H} 16 \mathrm{~A}$ & 107.8 & $\mathrm{H} 30 \mathrm{~A}-\mathrm{C} 30-\mathrm{H} 30 \mathrm{~B}$ & 108.6 \\
\hline $\mathrm{C} 17-\mathrm{C} 16-\mathrm{H} 16 \mathrm{~B}$ & 107.8 & $\mathrm{C} 31-\mathrm{C} 30-\mathrm{H} 30 \mathrm{~A}$ & 110.3 \\
\hline $\mathrm{C} 17-\mathrm{C} 16-\mathrm{H} 16 \mathrm{C}$ & 107.1 & $\mathrm{C} 31-\mathrm{C} 30-\mathrm{H} 30 \mathrm{~B}$ & 110.3 \\
\hline $\mathrm{C} 17-\mathrm{C} 16-\mathrm{H} 16 \mathrm{D}$ & 107.1 & $\mathrm{C} 30-\mathrm{C} 31-\mathrm{H} 31 \mathrm{~A}$ & 109.1 \\
\hline $\mathrm{H} 14 \mathrm{Cb}-\mathrm{C} 14 \mathrm{Bb}-\mathrm{H} 14 \mathrm{D}$ & 120.0 & $\mathrm{C} 30-\mathrm{C} 31-\mathrm{H} 31 \mathrm{~B}$ & 109.1 \\
\hline $\mathrm{C} 14 \mathrm{Aa}-\mathrm{PT} 1 \mathrm{Aa}-\mathrm{C} 15 \mathrm{~A}$ & $37.6(3)$ & $\mathrm{C} 30-\mathrm{C} 31-\mathrm{C} 32$ & $112.6(4)$ \\
\hline $\mathrm{C} 14 \mathrm{Aa}-\mathrm{C} 15 \mathrm{Aa}-\mathrm{H} 15 \mathrm{~A}$ & 111.4 & $\mathrm{H} 31 \mathrm{~A}-\mathrm{C} 31-\mathrm{H} 31 \mathrm{~B}$ & 107.8 \\
\hline PT1Aa $-\mathrm{C} 15 \mathrm{Aa}-\mathrm{H} 15 \mathrm{~A}$ & 111.4 & $\mathrm{C} 32-\mathrm{C} 31-\mathrm{H} 31 \mathrm{~A}$ & 109.1 \\
\hline $\mathrm{C} 14 \mathrm{Bb}-\mathrm{C} 15 \mathrm{Bb}-\mathrm{H} 15 \mathrm{~B}$ & 110.6 & $\mathrm{C} 32-\mathrm{C} 31-\mathrm{H} 31 \mathrm{~B}$ & 109.1 \\
\hline $\mathrm{PT} 1 \mathrm{Bb}-\mathrm{C} 15 \mathrm{Bb}-\mathrm{H} 15 \mathrm{~B}$ & 110.6 & $\mathrm{C} 31-\mathrm{C} 32-\mathrm{H} 32 \mathrm{~A}$ & 109.5 \\
\hline $\mathrm{C} 14 \mathrm{Aa}-\mathrm{C} 15 \mathrm{Aa}-\mathrm{C} 16$ & $128.8(7)$ & $\mathrm{C} 31-\mathrm{C} 32-\mathrm{H} 32 \mathrm{~B}$ & 109.5 \\
\hline $\mathrm{C} 15 \mathrm{Aa}-\mathrm{C} 16-\mathrm{H} 16 \mathrm{~A}$ & 107.8 & $\mathrm{C} 31-\mathrm{C} 32-\mathrm{H} 32 \mathrm{C}$ & 109.5 \\
\hline $\mathrm{C} 15 \mathrm{Aa}-\mathrm{C} 16-\mathrm{H} 16 \mathrm{~B}$ & 107.8 & $\mathrm{H} 32 \mathrm{~A}-\mathrm{C} 32-\mathrm{H} 32 \mathrm{~B}$ & 109.5 \\
\hline $\mathrm{H} 16 \mathrm{Aa}-\mathrm{C} 16-\mathrm{H} 16 \mathrm{~B}$ & 107.2 & $\mathrm{H} 32 \mathrm{~A}-\mathrm{C} 32-\mathrm{H} 32 \mathrm{C}$ & 109.5 \\
\hline $\mathrm{C} 15 \mathrm{Bb}-\mathrm{C} 16-\mathrm{H} 16 \mathrm{C}$ & 107.1 & $\mathrm{H} 32 \mathrm{~B}-\mathrm{C} 32-\mathrm{H} 32 \mathrm{C}$ & 109.5 \\
\hline $\mathrm{PT} 1 \mathrm{Aa}-\mathrm{N} 4-\mathrm{C} 5-\mathrm{C} 6$ & $172.5(4)$ & $\mathrm{C} 10-\mathrm{C} 11-\mathrm{C} 12-\mathrm{C} 13$ & $-0.9(7)$ \\
\hline $\mathrm{PT} 1 \mathrm{Bb}-\mathrm{N} 4-\mathrm{C} 5-\mathrm{C} 6$ & $-173.3(4)$ & $\mathrm{C} 11-\mathrm{C} 12-\mathrm{C} 13-\mathrm{N} 4$ & $179.0(4)$ \\
\hline $\mathrm{PT} 1 \mathrm{Aa}-\mathrm{N} 4-\mathrm{C} 13-\mathrm{C} 8$ & $-172.7(3)$ & $\mathrm{C} 11-\mathrm{C} 12-\mathrm{C} 13-\mathrm{C} 8$ & $0.3(7)$ \\
\hline $\mathrm{PT} 1 \mathrm{Bb}-\mathrm{C} 14 \mathrm{Bb}-\mathrm{C} 15 \mathrm{Bb}-\mathrm{C} 16$ & $109.1(16)$ & $\mathrm{C} 13-\mathrm{N} 4-\mathrm{C} 5-\mathrm{C} 6$ & $-1.5(8)$ \\
\hline $\mathrm{PT} 1 \mathrm{Bb}-\mathrm{N} 4-\mathrm{C} 13-\mathrm{C} 8$ & $172.2(4)$ & $\mathrm{C} 13-\mathrm{C} 8-\mathrm{C} 9-\mathrm{C} 10$ & $-1.6(7)$ \\
\hline $\mathrm{PT} 1 \mathrm{Aa}-\mathrm{N} 4-\mathrm{C} 13-\mathrm{C} 12$ & $8.6(6)$ & $\mathrm{C} 16-\mathrm{C} 17-\mathrm{C} 18-\mathrm{C} 19$ & $179.7(4)$ \\
\hline $\mathrm{PT} 1 \mathrm{Bb}-\mathrm{N} 4-\mathrm{C} 13-\mathrm{C} 12$ & $-6.4(6)$ & $\mathrm{C} 16-\mathrm{C} 17-\mathrm{C} 22-\mathrm{C} 21$ & $-179.4(5)$ \\
\hline $\mathrm{C} 15 \mathrm{Bb}-\mathrm{C} 16-\mathrm{C} 17-\mathrm{C} 18$ & $-51.0(10)$ & $\mathrm{C} 17-\mathrm{C} 18-\mathrm{C} 19-\mathrm{C} 20$ & $-1.1(7)$ \\
\hline
\end{tabular}




$\begin{array}{ll}\text { PT1Aa-C14Aa-C15Aa-C16 } & -109.6(7) \\ \text { PT1Aa-C15Aa-C16-C17 } & 51.4(7) \\ \text { C14Bb-C15Bb-C16-C17 } & -136.9(16) \\ \text { C14Aa-C15Aa-C16-C17 } & 136.3(9) \\ \text { PT1Bb-C15Bb-C16-C17 } & -47.8(11) \\ \text { C15Aa-C16-C17-C18 } & -117.4(6) \\ \text { N4-C5-C6-C7 } & 0.3(8) \\ \text { C5-N4-C13-C } & 1.0(7) \\ \text { C5-N4-C13-C12 } & -177.6(4) \\ \text { C5-C6-C7-C } & 1.2(7) \\ \text { C6-C7-C8-C9 } & 176.6(5) \\ \text { C6-C7-C8-C13 } & -1.5(7) \\ \text { C7-C8-C9-C10 } & -179.7(5) \\ \text { C7-C8-C13-N4 } & 0.4(7) \\ \text { C7-C8-C13-C12 } & 179.1(4) \\ \text { C8-C9-C10-C11 } & 1.1(7) \\ \text { C9-C8-C13-N4 } & -177.8(4) \\ \text { C9-C8-C13-C12 } & 0.9(6) \\ \text { C9-C10-C11-C12 } & 0.2(8) \\ \text { C15Bb-C16-C17-C22 } & 129.1(9) \\ \text { C15Aa-C16-C17-C22 } & 62.7(7)\end{array}$

$179.1(4)$

$0.7(7)$

$2.3(7)$

$-178.1(4)$

$0.1(7)$

$-2.1(7)$

$175.4(4)$

$-179.7(4)$

$0.6(8)$

$-172.9(4)$

$-5.0(7)$

$-0.4(7)$

$-177.8(4)$

$1.8(6)$

$178.4(5)$

7.9 (7)

$-174.2(4)$

$-175.1(4)$

$166.3(4)$

$2.9(7)$

$61.8(6)$

Hydrogen-bond geometry $\left(\AA,{ }^{\circ}\right)$

$C g 1$ is the centroid of ring $\mathrm{C} 17-\mathrm{C} 22$.

\begin{tabular}{lllll}
\hline$D-\mathrm{H} \cdots A$ & $D-\mathrm{H}$ & $\mathrm{H} \cdots A$ & $D \cdots A$ & $D-\mathrm{H} \cdots A$ \\
\hline $\mathrm{C} 6-\mathrm{H} 6 \cdots \mathrm{O} 28^{\mathrm{ii}}$ & 0.95 & 2.47 & $3.404(7)$ & 169 \\
$\mathrm{C} 7-\mathrm{H} 7 \cdots \mathrm{O} 23^{\mathrm{ii}}$ & 0.95 & 2.39 & $3.324(7)$ & 168 \\
$\mathrm{C} 24-\mathrm{H} 24 B \cdots \mathrm{O} 23^{\mathrm{iiii}}$ & 0.98 & 2.53 & $3.287(6)$ & 134 \\
$\mathrm{C} 12-\mathrm{H} 12 \cdots C g 1$ & 0.95 & 2.93 & $3.732(6)$ & 142 \\
\hline
\end{tabular}

Symmetry codes: (i) $-x+2,-y+2,-z+1$; (ii) $-x+2,-y+1,-z+1$.

[ $\eta^{2}$-4-Allyl-2-methoxy-1-(propoxycarbonylmethoxy)benzene]chlorido(quinolin-8-olato- $\kappa^{2} N, O$ ) platinum(II) (chi30)

\section{Crystal data}

$\left[\mathrm{Pt}\left(\mathrm{C}_{9} \mathrm{H}_{6} \mathrm{NO}\right) \mathrm{Cl}\left(\mathrm{C}_{15} \mathrm{H}_{20} \mathrm{O}_{4}\right)\right]$

$M_{r}=639.00$

Triclinic, $P \overline{1}$

$a=8.3447(2) \AA$

$b=11.9191(4) \AA$

$c=12.9315(5) \AA$

$\alpha=63.296(4)^{\circ}$

$\beta=84.618(3)^{\circ}$

$\gamma=76.484(3)^{\circ}$

$V=1117.09(7) \AA^{3}$

$Z=2$

$F(000)=624$

$D_{\mathrm{x}}=1.900 \mathrm{Mg} \mathrm{m}^{-3}$

Mo $K \alpha$ radiation, $\lambda=0.71073 \AA$

Cell parameters from 12015 reflections

$\theta=3.0-29.0^{\circ}$

$\mu=6.44 \mathrm{~mm}^{-1}$

$T=100 \mathrm{~K}$

Block, orange

$0.25 \times 0.25 \times 0.1 \mathrm{~mm}$ 


\section{Data collection}

Agilent SuperNova Dual Source diffractometer with an Eos detector

Radiation source: SuperNova (Mo) X-ray Source

Mirror monochromator

Detector resolution: 15.9631 pixels $\mathrm{mm}^{-1}$

$\omega$ scans

Absorption correction: multi-scan

(CrysAlis PRO; Agilent, 2013)

\section{Refinement}

Refinement on $F^{2}$

Least-squares matrix: full

$R\left[F^{2}>2 \sigma\left(F^{2}\right)\right]=0.021$

$w R\left(F^{2}\right)=0.048$

$S=1.09$

4564 reflections

291 parameters

0 restraints
$T_{\min }=0.411, T_{\max }=1.000$

18255 measured reflections

4564 independent reflections

4417 reflections with $I>2 \sigma(I)$

$R_{\text {int }}=0.029$

$\theta_{\max }=26.4^{\circ}, \theta_{\min }=2.8^{\circ}$

$h=-10 \rightarrow 10$

$k=-14 \rightarrow 14$

$l=-16 \rightarrow 16$

Primary atom site location: heavy-atom method

Hydrogen site location: mixed

$\mathrm{H}$-atom parameters constrained

$w=1 /\left[\sigma^{2}\left(F_{0}^{2}\right)+(0.0163 P)^{2}+2.8225 P\right]$

where $P=\left(F_{\mathrm{o}}^{2}+2 F_{\mathrm{c}}^{2}\right) / 3$

$(\Delta / \sigma)_{\max }=0.002$

$\Delta \rho_{\max }=2.18 \mathrm{e} \AA^{-3}$

$\Delta \rho_{\min }=-1.45$ e $\AA^{-3}$

Special details

Geometry. All esds (except the esd in the dihedral angle between two 1.s. planes) are estimated using the full covariance matrix. The cell esds are taken into account individually in the estimation of esds in distances, angles and torsion angles; correlations between esds in cell parameters are only used when they are defined by crystal symmetry. An approximate (isotropic) treatment of cell esds is used for estimating esds involving 1.s. planes.

Fractional atomic coordinates and isotropic or equivalent isotropic displacement parameters $\left(\AA^{2}\right)$

\begin{tabular}{lllll}
\hline & $x$ & $y$ & $z$ & $U_{\text {iso }}^{*} / U_{\text {eq }}$ \\
\hline Pt1 & $0.04044(2)$ & $0.99699(2)$ & $0.32891(2)$ & $0.01151(5)$ \\
C113 & $0.16523(10)$ & $1.14992(8)$ & $0.18856(7)$ & $0.01867(17)$ \\
O12 & $-0.0616(3)$ & $0.8637(2)$ & $0.4578(2)$ & $0.0154(5)$ \\
O23 & $0.2621(3)$ & $0.5145(2)$ & $0.3564(2)$ & $0.0176(5)$ \\
O25 & $0.2664(3)$ & $0.5075(2)$ & $0.1596(2)$ & $0.0146(5)$ \\
O28 & $0.4923(3)$ & $0.3181(3)$ & $0.1420(2)$ & $0.0255(6)$ \\
O29 & $0.3771(3)$ & $0.3538(2)$ & $-0.02330(19)$ & $0.0153(5)$ \\
N2 & $0.2441(3)$ & $0.9061(2)$ & $0.4345(2)$ & $0.0112(5)$ \\
C3 & $0.3926(4)$ & $0.9321(3)$ & $0.4188(3)$ & $0.0146(7)$ \\
H3 & 0.4123 & 1.0059 & 0.3522 & $0.017^{*}$ \\
C4 & $0.5220(4)$ & $0.8532(3)$ & $0.4986(3)$ & $0.0154(7)$ \\
H4 & 0.6274 & 0.8743 & 0.4859 & $0.018^{*}$ \\
C5 & $0.4963(4)$ & $0.7459(3)$ & $0.5946(3)$ & $0.0136(7)$ \\
H5 & 0.5837 & 0.6924 & 0.6485 & $0.016^{*}$ \\
C6 & $0.3385(4)$ & $0.7147(3)$ & $0.6136(3)$ & $0.0123(6)$ \\
C7 & $0.2995(4)$ & $0.6068(3)$ & $0.7088(3)$ & $0.0151(7)$ \\
H7 & 0.3812 & 0.5480 & 0.7655 & $0.018^{*}$ \\
C8 & $0.1415(4)$ & $0.5875(3)$ & $0.7187(3)$ & $0.0179(7)$ \\
H8 & 0.1156 & 0.5142 & 0.7830 & $0.022^{*}$ \\
C9 & $0.0163(4)$ & $0.6730(3)$ & $0.6365(3)$ & $0.0167(7)$ \\
H9 & -0.0917 & 0.6570 & 0.6465 & $0.020^{*}$
\end{tabular}




$\begin{array}{lllll}\text { C10 } & 0.0502(4) & 0.7797(3) & 0.5419(3) & 0.0125(6) \\ \text { C11 } & 0.2137(4) & 0.7999(3) & 0.5310(3) & 0.0112(6) \\ \text { C14 } & -0.1965(4) & 1.1023(3) & 0.2518(3) & 0.0168(7) \\ \text { H14A } & -0.2815 & 1.0850 & 0.3047 & 0.020^{*} \\ \text { H14B } & -0.1540 & 1.1746 & 0.2327 & 0.020^{*} \\ \text { C15 } & -0.1322(4) & 1.0206(3) & 0.2011(3) & 0.0145(7) \\ \text { H15 } & -0.0979 & 1.0643 & 0.1209 & 0.017^{*} \\ \text { C16 } & -0.1942(4) & 0.9026(3) & 0.2278(3) & 0.0160(7) \\ \text { H16A } & -0.2944 & 0.9280 & 0.1802 & 0.019^{*} \\ \text { H16B } & -0.2267 & 0.8654 & 0.3100 & 0.019^{*} \\ \text { C17 } & -0.0716(4) & 0.7992(3) & 0.2064(3) & 0.0136(7) \\ \text { C18 } & 0.0381(4) & 0.7055(3) & 0.2943(3) & 0.0144(7) \\ \text { H18 } & 0.0358 & 0.7070 & 0.3673 & 0.017^{*} \\ \text { C19 } & 0.1504(4) & 0.6104(3) & 0.2758(3) & 0.0132(7) \\ \text { C20 } & 0.1528(4) & 0.6070(3) & 0.1684(3) & 0.0116(6) \\ \text { C21 } & 0.0445(4) & 0.6995(3) & 0.0812(3) & 0.0140(7) \\ \text { H21 } & 0.0452 & 0.6976 & 0.0085 & 0.017^{*} \\ \text { C22 } & -0.0659(4) & 0.7957(3) & 0.1008(3) & 0.0144(7) \\ \text { H22 } & -0.1385 & 0.8602 & 0.0402 & 0.017^{*} \\ \text { C24 } & 0.2638(5) & 0.5115(4) & 0.4676(3) & 0.0289(9) \\ \text { H24A } & 0.3460 & 0.4367 & 0.5173 & 0.043^{*} \\ \text { H24B } & 0.1547 & 0.5054 & 0.5022 & 0.043^{*} \\ \text { H24C } & 0.2919 & 0.5902 & 0.4598 & 0.043^{*} \\ \text { C26 } & 0.2514(4) & 0.4874(3) & 0.0616(3) & 0.0146(7) \\ \text { H26A } & 0.2601 & 0.5658 & -0.0102 & 0.018^{*} \\ \text { H26B } & 0.1429 & 0.4673 & 0.0611 & 0.018^{*} \\ \text { C27 } & 0.3883(4) & 0.3763(3) & 0.0677(3) & 0.0134(7) \\ \text { C30 } & 0.5000(5) & 0.2451(3) & -0.0251(3) & 0.0227(8) \\ \text { H30A } & 0.4733 & 0.1632 & 0.0331 & 0.027^{*} \\ \text { H30B } & 0.6105 & 0.2487 & -0.0065 & 0.027^{*} \\ \text { C31 } & 0.4988(5) & 0.2527(4) & -0.1449(3) & 0.0252(8) \\ \text { H31A } & 0.3863 & 0.2547 & -0.1651 & 0.030^{*} \\ \text { H31B } & 0.5313 & 0.3327 & -0.2023 & 0.030^{*} \\ \text { C32 } & 0.6175(5) & 0.1375(4) & -0.1479(4) & 0.0294(9) \\ \text { H32A } & 0.7285 & 0.1359 & -0.1276 & 0.044^{*} \\ \text { H32B } & 0.6177 & 0.1431 & -0.2259 & 0.044^{*} \\ \text { H32C } & 0.5833 & 0.0588 & -0.0922 & 0.044^{*} \\ & & & & \end{array}$

Atomic displacement parameters $\left(\AA^{2}\right)$

\begin{tabular}{lllllll}
\hline & $U^{11}$ & $U^{22}$ & $U^{33}$ & $U^{12}$ & $U^{13}$ & $U^{23}$ \\
\hline Pt1 & $0.01206(7)$ & $0.01043(7)$ & $0.01114(7)$ & $0.00036(5)$ & $-0.00234(5)$ & $-0.00484(5)$ \\
C113 & $0.0219(4)$ & $0.0151(4)$ & $0.0148(4)$ & $-0.0047(3)$ & $-0.0009(3)$ & $-0.0023(3)$ \\
O12 & $0.0083(11)$ & $0.0158(12)$ & $0.0217(13)$ & $-0.0014(9)$ & $-0.0011(9)$ & $-0.0082(10)$ \\
O23 & $0.0211(12)$ & $0.0163(12)$ & $0.0153(12)$ & $0.0041(10)$ & $-0.0066(10)$ & $-0.0094(10)$ \\
O25 & $0.0152(11)$ & $0.0143(11)$ & $0.0150(12)$ & $0.0034(9)$ & $-0.0024(9)$ & $-0.0097(10)$ \\
O28 & $0.0191(13)$ & $0.0301(15)$ & $0.0315(15)$ & $0.0090(11)$ & $-0.0115(11)$ & $-0.0217(13)$ \\
O29 & $0.0192(12)$ & $0.0137(11)$ & $0.0117(12)$ & $0.0025(9)$ & $-0.0004(9)$ & $-0.0074(9)$
\end{tabular}




$\begin{array}{lllllll}\mathrm{N} 2 & 0.0153(13) & 0.0102(13) & 0.0099(13) & -0.0015(11) & 0.0012(11) & -0.0068(11) \\ \text { C3 } & 0.0163(16) & 0.0157(16) & 0.0138(17) & -0.0052(13) & 0.0020(13) & -0.0078(14) \\ \text { C4 } & 0.0112(15) & 0.0200(17) & 0.0183(18) & -0.0039(13) & 0.0015(13) & -0.0113(14) \\ \text { C5 } & 0.0122(15) & 0.0149(16) & 0.0144(17) & 0.0028(13) & -0.0034(13) & -0.0090(13) \\ \text { C6 } & 0.0155(16) & 0.0113(15) & 0.0121(16) & 0.0004(12) & -0.0016(12) & -0.0082(13) \\ \text { C7 } & 0.0202(17) & 0.0131(16) & 0.0108(16) & -0.0003(13) & -0.0024(13) & -0.0054(13) \\ \text { C8 } & 0.0253(18) & 0.0150(16) & 0.0125(17) & -0.0065(14) & 0.0029(14) & -0.0048(14) \\ \text { C9 } & 0.0168(16) & 0.0188(17) & 0.0161(17) & -0.0062(14) & 0.0031(13) & -0.0085(14) \\ \text { C10 } & 0.0144(15) & 0.0127(15) & 0.0120(16) & -0.0006(12) & 0.0002(12) & -0.0078(13) \\ \text { C11 } & 0.0139(15) & 0.0120(15) & 0.0108(16) & -0.0022(12) & 0.0011(12) & -0.0081(13) \\ \text { C14 } & 0.0139(16) & 0.0171(17) & 0.0195(18) & 0.0022(13) & -0.0071(13) & -0.0095(14) \\ \text { C15 } & 0.0115(15) & 0.0162(16) & 0.0143(17) & 0.0014(13) & -0.0057(13) & -0.0063(14) \\ \text { C16 } & 0.0114(15) & 0.0185(17) & 0.0169(17) & 0.0014(13) & -0.0015(13) & -0.0085(14) \\ \text { C17 } & 0.0099(15) & 0.0116(15) & 0.0199(18) & -0.0019(12) & 0.0000(13) & -0.0076(14) \\ \text { C18 } & 0.0147(16) & 0.0158(16) & 0.0157(17) & -0.0031(13) & -0.0003(13) & -0.0094(14) \\ \text { C19 } & 0.0117(15) & 0.0114(15) & 0.0173(17) & -0.0024(12) & -0.0013(13) & -0.0067(13) \\ \text { C20 } & 0.0102(14) & 0.0095(15) & 0.0152(17) & -0.0028(12) & 0.0030(12) & -0.0056(13) \\ \text { C21 } & 0.0143(15) & 0.0151(16) & 0.0126(16) & -0.0032(13) & 0.0010(13) & -0.0063(13) \\ \text { C22 } & 0.0125(15) & 0.0109(15) & 0.0167(17) & -0.0007(12) & -0.0022(13) & -0.0037(13) \\ \text { C24 } & 0.035(2) & 0.030(2) & 0.021(2) & 0.0109(18) & -0.0132(17) & -0.0170(17) \\ \text { C26 } & 0.0141(16) & 0.0143(16) & 0.0141(17) & 0.0002(13) & -0.0007(13) & -0.0065(14) \\ \text { C27 } & 0.0122(15) & 0.0121(15) & 0.0163(17) & -0.0036(13) & 0.0020(13) & -0.0065(13) \\ \text { C30 } & 0.0223(18) & 0.0186(18) & 0.027(2) & -0.0013(15) & 0.0014(15) & -0.0112(16) \\ \text { C31 } & 0.0216(19) & 0.029(2) & 0.030(2) & -0.0067(16) & 0.0041(16) & -0.0184(18) \\ \text { C32 } & 0.028(2) & 0.030(2) & 0.037(2) & -0.0081(17) & 0.0065(18) & -0.0201(19) \\ & & & & & & \end{array}$

Geometric parameters $\left(A,{ }^{\circ}\right)$

\begin{tabular}{llll}
\hline Pt1-C113 & $2.2935(8)$ & $\mathrm{C} 14-\mathrm{H} 14 \mathrm{~B}$ & 0.9296 \\
$\mathrm{Pt} 1-\mathrm{O} 12$ & $2.003(2)$ & $\mathrm{C} 14-\mathrm{C} 15$ & $1.389(5)$ \\
$\mathrm{Pt} 1-\mathrm{N} 2$ & $2.042(3)$ & $\mathrm{C} 15-\mathrm{H} 15$ & 0.9789 \\
$\mathrm{Pt} 1-\mathrm{C} 14$ & $2.136(3)$ & $\mathrm{C} 15-\mathrm{C} 16$ & $1.495(5)$ \\
$\mathrm{Pt} 1-\mathrm{C} 15$ & $2.174(3)$ & $\mathrm{C} 16-\mathrm{H} 16 \mathrm{~A}$ & 0.9900 \\
$\mathrm{O} 12-\mathrm{C} 10$ & $1.353(4)$ & $\mathrm{C} 16-\mathrm{H} 16 \mathrm{~B}$ & 0.9900 \\
$\mathrm{O} 23-\mathrm{C} 19$ & $1.370(4)$ & $\mathrm{C} 16-\mathrm{C} 17$ & $1.519(4)$ \\
$\mathrm{O} 23-\mathrm{C} 24$ & $1.423(4)$ & $\mathrm{C} 17-\mathrm{C} 18$ & $1.398(5)$ \\
$\mathrm{O} 25-\mathrm{C} 20$ & $1.376(4)$ & $\mathrm{C} 17-\mathrm{C} 22$ & $1.380(5)$ \\
$\mathrm{O} 25-\mathrm{C} 26$ & $1.413(4)$ & $\mathrm{C} 18-\mathrm{H} 18$ & 0.9500 \\
$\mathrm{O} 28-\mathrm{C} 27$ & $1.198(4)$ & $\mathrm{C} 18-\mathrm{C} 19$ & $1.388(5)$ \\
$\mathrm{O} 29-\mathrm{C} 27$ & $1.334(4)$ & $\mathrm{C} 19-\mathrm{C} 20$ & $1.405(5)$ \\
$\mathrm{O} 29-\mathrm{C} 30$ & $1.461(4)$ & $\mathrm{C} 20-\mathrm{C} 21$ & $1.383(4)$ \\
$\mathrm{N} 2-\mathrm{C} 3$ & $1.323(4)$ & $\mathrm{C} 21-\mathrm{H} 21$ & 0.9500 \\
$\mathrm{~N} 2-\mathrm{C} 11$ & $1.376(4)$ & $\mathrm{C} 21-\mathrm{C} 22$ & $1.397(5)$ \\
$\mathrm{C} 3-\mathrm{H} 3$ & 0.9500 & $\mathrm{C} 22-\mathrm{H} 22$ & 0.9500 \\
$\mathrm{C} 3-\mathrm{C} 4$ & $1.406(5)$ & $\mathrm{C} 24-\mathrm{H} 24 \mathrm{~A}$ & 0.9800 \\
$\mathrm{C} 4-\mathrm{H} 4$ & 0.9500 & $\mathrm{C} 24-\mathrm{H} 24 \mathrm{~B}$ & 0.9800 \\
$\mathrm{C} 4-\mathrm{C} 5$ & $1.369(5)$ & $\mathrm{C} 24-\mathrm{H} 24 \mathrm{C}$ & 0.9800 \\
$\mathrm{C} 5-\mathrm{H} 5$ & 0.9500 & $\mathrm{C} 26-\mathrm{H} 26 \mathrm{~A}$ & 0.9900
\end{tabular}




\begin{tabular}{|c|c|c|c|}
\hline $\mathrm{C} 5-\mathrm{C} 6$ & $1.421(5)$ & $\mathrm{C} 26-\mathrm{H} 26 \mathrm{~B}$ & 0.9900 \\
\hline $\mathrm{C} 6-\mathrm{C} 7$ & $1.404(5)$ & $\mathrm{C} 26-\mathrm{C} 27$ & $1.510(4)$ \\
\hline $\mathrm{C} 6-\mathrm{C} 11$ & $1.413(4)$ & $\mathrm{C} 30-\mathrm{H} 30 \mathrm{~A}$ & 0.9900 \\
\hline $\mathrm{C} 7-\mathrm{H} 7$ & 0.9500 & $\mathrm{C} 30-\mathrm{H} 30 \mathrm{~B}$ & 0.9900 \\
\hline $\mathrm{C} 7-\mathrm{C} 8$ & $1.376(5)$ & $\mathrm{C} 30-\mathrm{C} 31$ & $1.511(5)$ \\
\hline $\mathrm{C} 8-\mathrm{H} 8$ & 0.9500 & $\mathrm{C} 31-\mathrm{H} 31 \mathrm{~A}$ & 0.9900 \\
\hline $\mathrm{C} 8-\mathrm{C} 9$ & $1.413(5)$ & $\mathrm{C} 31-\mathrm{H} 31 \mathrm{~B}$ & 0.9900 \\
\hline $\mathrm{C} 9-\mathrm{H} 9$ & 0.9500 & C31-C32 & $1.508(5)$ \\
\hline $\mathrm{C} 9-\mathrm{C} 10$ & $1.378(5)$ & $\mathrm{C} 32-\mathrm{H} 32 \mathrm{~A}$ & 0.9800 \\
\hline $\mathrm{C} 10-\mathrm{C} 11$ & $1.423(4)$ & $\mathrm{C} 32-\mathrm{H} 32 \mathrm{~B}$ & 0.9800 \\
\hline $\mathrm{C} 14-\mathrm{H} 14 \mathrm{~A}$ & 0.9291 & $\mathrm{C} 32-\mathrm{H} 32 \mathrm{C}$ & 0.9800 \\
\hline $\mathrm{O} 12-\mathrm{Pt} 1-\mathrm{Cl} 13$ & $176.98(7)$ & $\mathrm{C} 15-\mathrm{C} 16-\mathrm{H} 16 \mathrm{~B}$ & 108.6 \\
\hline $\mathrm{O} 12-\mathrm{Pt} 1-\mathrm{N} 2$ & $82.92(10)$ & $\mathrm{C} 15-\mathrm{C} 16-\mathrm{C} 17$ & $114.8(3)$ \\
\hline $\mathrm{O} 12-\mathrm{Pt} 1-\mathrm{C} 14$ & $90.86(12)$ & $\mathrm{H} 16 \mathrm{~A}-\mathrm{C} 16-\mathrm{H} 16 \mathrm{~B}$ & 107.5 \\
\hline $\mathrm{O} 12-\mathrm{Pt} 1-\mathrm{C} 15$ & $92.59(11)$ & $\mathrm{C} 17-\mathrm{C} 16-\mathrm{H} 16 \mathrm{~A}$ & 108.6 \\
\hline N2-Pt1-C113 & $94.62(8)$ & $\mathrm{C} 17-\mathrm{C} 16-\mathrm{H} 16 \mathrm{~B}$ & 108.6 \\
\hline $\mathrm{N} 2-\mathrm{Pt} 1-\mathrm{C} 14$ & $166.29(12)$ & $\mathrm{C} 18-\mathrm{C} 17-\mathrm{C} 16$ & $120.0(3)$ \\
\hline $\mathrm{N} 2-\mathrm{Pt} 1-\mathrm{C} 15$ & $154.39(11)$ & $\mathrm{C} 22-\mathrm{C} 17-\mathrm{C} 16$ & $121.1(3)$ \\
\hline $\mathrm{C} 14-\mathrm{Pt} 1-\mathrm{Cl13}$ & $91.17(10)$ & $\mathrm{C} 22-\mathrm{C} 17-\mathrm{C} 18$ & $118.9(3)$ \\
\hline $\mathrm{C} 14-\mathrm{Pt} 1-\mathrm{C} 15$ & $37.59(13)$ & $\mathrm{C} 17-\mathrm{C} 18-\mathrm{H} 18$ & 119.8 \\
\hline $\mathrm{C} 15-\mathrm{Pt} 1-\mathrm{C} 113$ & $90.38(9)$ & $\mathrm{C} 19-\mathrm{C} 18-\mathrm{C} 17$ & $120.5(3)$ \\
\hline $\mathrm{C} 10-\mathrm{O} 12-\mathrm{Pt} 1$ & $111.51(19)$ & $\mathrm{C} 19-\mathrm{C} 18-\mathrm{H} 18$ & 119.8 \\
\hline $\mathrm{C} 19-\mathrm{O} 23-\mathrm{C} 24$ & $118.0(3)$ & $\mathrm{O} 23-\mathrm{C} 19-\mathrm{C} 18$ & $124.8(3)$ \\
\hline $\mathrm{C} 20-\mathrm{O} 25-\mathrm{C} 26$ & $116.5(2)$ & $\mathrm{O} 23-\mathrm{C} 19-\mathrm{C} 20$ & $115.3(3)$ \\
\hline $\mathrm{C} 27-\mathrm{O} 29-\mathrm{C} 30$ & $114.8(3)$ & $\mathrm{C} 18-\mathrm{C} 19-\mathrm{C} 20$ & $119.9(3)$ \\
\hline $\mathrm{C} 3-\mathrm{N} 2-\mathrm{Pt} 1$ & $129.5(2)$ & $\mathrm{O} 25-\mathrm{C} 20-\mathrm{C} 19$ & $115.4(3)$ \\
\hline $\mathrm{C} 3-\mathrm{N} 2-\mathrm{C} 11$ & $119.8(3)$ & $\mathrm{O} 25-\mathrm{C} 20-\mathrm{C} 21$ & $124.8(3)$ \\
\hline $\mathrm{C} 11-\mathrm{N} 2-\mathrm{Pt} 1$ & $110.6(2)$ & $\mathrm{C} 21-\mathrm{C} 20-\mathrm{C} 19$ & $119.8(3)$ \\
\hline $\mathrm{N} 2-\mathrm{C} 3-\mathrm{H} 3$ & 119.2 & $\mathrm{C} 20-\mathrm{C} 21-\mathrm{H} 21$ & 120.2 \\
\hline $\mathrm{N} 2-\mathrm{C} 3-\mathrm{C} 4$ & $121.5(3)$ & $\mathrm{C} 20-\mathrm{C} 21-\mathrm{C} 22$ & $119.5(3)$ \\
\hline $\mathrm{C} 4-\mathrm{C} 3-\mathrm{H} 3$ & 119.2 & $\mathrm{C} 22-\mathrm{C} 21-\mathrm{H} 21$ & 120.2 \\
\hline $\mathrm{C} 3-\mathrm{C} 4-\mathrm{H} 4$ & 120.0 & $\mathrm{C} 17-\mathrm{C} 22-\mathrm{C} 21$ & $121.4(3)$ \\
\hline $\mathrm{C} 5-\mathrm{C} 4-\mathrm{C} 3$ & $120.0(3)$ & $\mathrm{C} 17-\mathrm{C} 22-\mathrm{H} 22$ & 119.3 \\
\hline $\mathrm{C} 5-\mathrm{C} 4-\mathrm{H} 4$ & 120.0 & $\mathrm{C} 21-\mathrm{C} 22-\mathrm{H} 22$ & 119.3 \\
\hline $\mathrm{C} 4-\mathrm{C} 5-\mathrm{H} 5$ & 120.1 & $\mathrm{O} 23-\mathrm{C} 24-\mathrm{H} 24 \mathrm{~A}$ & 109.5 \\
\hline $\mathrm{C} 4-\mathrm{C} 5-\mathrm{C} 6$ & $119.9(3)$ & $\mathrm{O} 23-\mathrm{C} 24-\mathrm{H} 24 \mathrm{~B}$ & 109.5 \\
\hline $\mathrm{C} 6-\mathrm{C} 5-\mathrm{H} 5$ & 120.1 & $\mathrm{O} 23-\mathrm{C} 24-\mathrm{H} 24 \mathrm{C}$ & 109.5 \\
\hline $\mathrm{C} 7-\mathrm{C} 6-\mathrm{C} 5$ & $124.3(3)$ & $\mathrm{H} 24 \mathrm{~A}-\mathrm{C} 24-\mathrm{H} 24 \mathrm{~B}$ & 109.5 \\
\hline $\mathrm{C} 7-\mathrm{C} 6-\mathrm{C} 11$ & $118.8(3)$ & $\mathrm{H} 24 \mathrm{~A}-\mathrm{C} 24-\mathrm{H} 24 \mathrm{C}$ & 109.5 \\
\hline $\mathrm{C} 11-\mathrm{C} 6-\mathrm{C} 5$ & $116.9(3)$ & $\mathrm{H} 24 \mathrm{~B}-\mathrm{C} 24-\mathrm{H} 24 \mathrm{C}$ & 109.5 \\
\hline $\mathrm{C} 6-\mathrm{C} 7-\mathrm{H} 7$ & 120.5 & $\mathrm{O} 25-\mathrm{C} 26-\mathrm{H} 26 \mathrm{~A}$ & 110.1 \\
\hline $\mathrm{C} 8-\mathrm{C} 7-\mathrm{C} 6$ & $119.1(3)$ & $\mathrm{O} 25-\mathrm{C} 26-\mathrm{H} 26 \mathrm{~B}$ & 110.1 \\
\hline $\mathrm{C} 8-\mathrm{C} 7-\mathrm{H} 7$ & 120.5 & $\mathrm{O} 25-\mathrm{C} 26-\mathrm{C} 27$ & $108.0(3)$ \\
\hline $\mathrm{C} 7-\mathrm{C} 8-\mathrm{H} 8$ & 118.9 & $\mathrm{H} 26 \mathrm{~A}-\mathrm{C} 26-\mathrm{H} 26 \mathrm{~B}$ & 108.4 \\
\hline $\mathrm{C} 7-\mathrm{C} 8-\mathrm{C} 9$ & $122.2(3)$ & $\mathrm{C} 27-\mathrm{C} 26-\mathrm{H} 26 \mathrm{~A}$ & 110.1 \\
\hline $\mathrm{C} 9-\mathrm{C} 8-\mathrm{H} 8$ & 118.9 & $\mathrm{C} 27-\mathrm{C} 26-\mathrm{H} 26 \mathrm{~B}$ & 110.1 \\
\hline $\mathrm{C} 8-\mathrm{C} 9-\mathrm{H} 9$ & 119.8 & $\mathrm{O} 28-\mathrm{C} 27-\mathrm{O} 29$ & $125.1(3)$ \\
\hline
\end{tabular}




\begin{tabular}{|c|c|}
\hline $\mathrm{C} 10-\mathrm{C} 9-\mathrm{C} 8$ & $120.3(3)$ \\
\hline $\mathrm{C} 10-\mathrm{C} 9-\mathrm{H} 9$ & 119.8 \\
\hline $\mathrm{O} 12-\mathrm{C} 10-\mathrm{C} 9$ & $123.7(3)$ \\
\hline $\mathrm{O} 12-\mathrm{C} 10-\mathrm{C} 11$ & $118.5(3)$ \\
\hline $\mathrm{C} 9-\mathrm{C} 10-\mathrm{C} 11$ & $117.7(3)$ \\
\hline $\mathrm{N} 2-\mathrm{C} 11-\mathrm{C} 6$ & $121.8(3)$ \\
\hline $\mathrm{N} 2-\mathrm{C} 11-\mathrm{C} 10$ & $116.2(3)$ \\
\hline $\mathrm{C} 6-\mathrm{C} 11-\mathrm{C} 10$ & $121.9(3)$ \\
\hline $\mathrm{Pt} 1-\mathrm{C} 14-\mathrm{H} 14 \mathrm{~A}$ & 112.7 \\
\hline Pt1-C14-H14B & 84.8 \\
\hline $\mathrm{H} 14 \mathrm{~A}-\mathrm{C} 14-\mathrm{H} 14 \mathrm{~B}$ & 120.0 \\
\hline $\mathrm{C} 15-\mathrm{C} 14-\mathrm{Pt} 1$ & $72.67(19)$ \\
\hline $\mathrm{C} 15-\mathrm{C} 14-\mathrm{H} 14 \mathrm{~A}$ & 120.4 \\
\hline $\mathrm{C} 15-\mathrm{C} 14-\mathrm{H} 14 \mathrm{~B}$ & 119.7 \\
\hline $\mathrm{Pt} 1-\mathrm{C} 15-\mathrm{H} 15$ & 114.1 \\
\hline $\mathrm{C} 14-\mathrm{C} 15-\mathrm{Pt} 1$ & $69.75(19)$ \\
\hline $\mathrm{C} 14-\mathrm{C} 15-\mathrm{H} 15$ & 114.2 \\
\hline $\mathrm{C} 14-\mathrm{C} 15-\mathrm{C} 16$ & $122.6(3)$ \\
\hline $\mathrm{C} 16-\mathrm{C} 15-\mathrm{Pt} 1$ & $114.4(2)$ \\
\hline $\mathrm{C} 16-\mathrm{C} 15-\mathrm{H} 15$ & 114.2 \\
\hline $\mathrm{C} 15-\mathrm{C} 16-\mathrm{H} 16 \mathrm{~A}$ & 108.6 \\
\hline Pt1-O12-C10-C9 & $-175.2(3)$ \\
\hline $\mathrm{Pt} 1-\mathrm{O} 12-\mathrm{C} 10-\mathrm{C} 11$ & $3.0(3)$ \\
\hline $\mathrm{Pt} 1-\mathrm{N} 2-\mathrm{C} 3-\mathrm{C} 4$ & $-175.9(2)$ \\
\hline $\mathrm{Pt} 1-\mathrm{N} 2-\mathrm{C} 11-\mathrm{C} 6$ & $175.2(2)$ \\
\hline $\mathrm{Pt} 1-\mathrm{N} 2-\mathrm{C} 11-\mathrm{C} 10$ & $-3.8(3)$ \\
\hline $\mathrm{Pt} 1-\mathrm{C} 14-\mathrm{C} 15-\mathrm{C} 16$ & $106.6(3)$ \\
\hline $\mathrm{Pt} 1-\mathrm{C} 15-\mathrm{C} 16-\mathrm{C} 17$ & $-75.3(3)$ \\
\hline $\mathrm{O} 12-\mathrm{C} 10-\mathrm{C} 11-\mathrm{N} 2$ & $0.6(4)$ \\
\hline $\mathrm{O} 12-\mathrm{C} 10-\mathrm{C} 11-\mathrm{C} 6$ & $-178.4(3)$ \\
\hline $\mathrm{O} 23-\mathrm{C} 19-\mathrm{C} 20-\mathrm{O} 25$ & $0.3(4)$ \\
\hline $\mathrm{O} 23-\mathrm{C} 19-\mathrm{C} 20-\mathrm{C} 21$ & $179.9(3)$ \\
\hline $\mathrm{O} 25-\mathrm{C} 20-\mathrm{C} 21-\mathrm{C} 22$ & $179.7(3)$ \\
\hline $\mathrm{O} 25-\mathrm{C} 26-\mathrm{C} 27-\mathrm{O} 28$ & $-1.3(5)$ \\
\hline $\mathrm{O} 25-\mathrm{C} 26-\mathrm{C} 27-\mathrm{O} 29$ & $179.5(3)$ \\
\hline $\mathrm{O} 29-\mathrm{C} 30-\mathrm{C} 31-\mathrm{C} 32$ & $-176.7(3)$ \\
\hline $\mathrm{N} 2-\mathrm{C} 3-\mathrm{C} 4-\mathrm{C} 5$ & $0.5(5)$ \\
\hline $\mathrm{C} 3-\mathrm{N} 2-\mathrm{C} 11-\mathrm{C} 6$ & $-1.7(5)$ \\
\hline $\mathrm{C} 3-\mathrm{N} 2-\mathrm{C} 11-\mathrm{C} 10$ & $179.3(3)$ \\
\hline $\mathrm{C} 3-\mathrm{C} 4-\mathrm{C} 5-\mathrm{C} 6$ & $-0.1(5)$ \\
\hline $\mathrm{C} 4-\mathrm{C} 5-\mathrm{C} 6-\mathrm{C} 7$ & $179.7(3)$ \\
\hline $\mathrm{C} 4-\mathrm{C} 5-\mathrm{C} 6-\mathrm{C} 11$ & $-1.1(5)$ \\
\hline $\mathrm{C} 5-\mathrm{C} 6-\mathrm{C} 7-\mathrm{C} 8$ & $179.1(3)$ \\
\hline $\mathrm{C} 5-\mathrm{C} 6-\mathrm{C} 11-\mathrm{N} 2$ & $2.0(5)$ \\
\hline $\mathrm{C} 5-\mathrm{C} 6-\mathrm{C} 11-\mathrm{C} 10$ & $-179.0(3)$ \\
\hline $\mathrm{C} 6-\mathrm{C} 7-\mathrm{C} 8-\mathrm{C} 9$ & $-0.3(5)$ \\
\hline $\mathrm{C} 7-\mathrm{C} 6-\mathrm{C} 11-\mathrm{N} 2$ & $-178.7(3)$ \\
\hline
\end{tabular}

$\begin{array}{ll}\mathrm{O} 28-\mathrm{C} 27-\mathrm{C} 26 & 125.3(3) \\ \mathrm{O} 29-\mathrm{C} 27-\mathrm{C} 26 & 109.6(3) \\ \mathrm{O} 29-\mathrm{C} 30-\mathrm{H} 30 \mathrm{~A} & 110.1 \\ \mathrm{O} 29-\mathrm{C} 30-\mathrm{H} 30 \mathrm{~B} & 110.1 \\ \mathrm{O} 29-\mathrm{C} 30-\mathrm{C} 31 & 108.1(3) \\ \mathrm{H} 30 \mathrm{~A}-\mathrm{C} 30-\mathrm{H} 30 \mathrm{~B} & 110.1 \\ \mathrm{C} 31-\mathrm{C} 30-\mathrm{H} 30 \mathrm{~A} & 110.1 \\ \mathrm{C} 31-\mathrm{C} 30-\mathrm{H} 30 \mathrm{~B} & 109.8 \\ \mathrm{C} 30-\mathrm{C} 31-\mathrm{H} 31 \mathrm{~A} & 109.8 \\ \mathrm{C} 30-\mathrm{C} 31-\mathrm{H} 31 \mathrm{~B} & 108.2 \\ \mathrm{H} 31 \mathrm{~A}-\mathrm{C} 31-\mathrm{H} 31 \mathrm{~B} & 109.5(3) \\ \mathrm{C} 32-\mathrm{C} 31-\mathrm{C} 30 & 109.8 \\ \mathrm{C} 32-\mathrm{C} 31-\mathrm{H} 31 \mathrm{~A} & 109.8 \\ \mathrm{C} 32-\mathrm{C} 31-\mathrm{H} 31 \mathrm{~B} & 109.5 \\ \mathrm{C} 31-\mathrm{C} 32-\mathrm{H} 32 \mathrm{~A} & 109.5 \\ \mathrm{C} 31-\mathrm{C} 32-\mathrm{H} 32 \mathrm{~B} & 109.5 \\ \mathrm{C} 31-\mathrm{C} 32-\mathrm{H} 32 \mathrm{C} & 109.5 \\ \mathrm{H} 32 \mathrm{~A}-\mathrm{C} 32-\mathrm{H} 32 \mathrm{~B} & 109.5 \\ \mathrm{H} 32 \mathrm{~A}-\mathrm{C} 32-\mathrm{H} 32 \mathrm{C} & 109.5 \\ \mathrm{H} 32 \mathrm{~B}-\mathrm{C} 32-\mathrm{H} 32 \mathrm{C} & \end{array}$

$\mathrm{C} 8-\mathrm{C} 9-\mathrm{C} 10-\mathrm{O} 12$

$177.9(3)$

$-0.3(5)$

$178.9(3)$

$-0.1(5)$

$0.4(5)$

$-0.1(5)$

$-156.0(3)$

88.9 (4)

$-91.0(4)$

$179.9(3)$

$-178.8(3)$

$-179.8(3)$

$-0.8(5)$

$1.3(5)$

$-178.7(3)$

$0.8(5)$

$0.2(5)$

$179.0(3)$

$-1.3(5)$

$-0.3(5)$

$0.1(5)$

$-178.9(3)$

$168.6(3)$

$-10.9(4)$

$-166.0(3)$

$2.8(5)$ 

$\mathrm{C} 7-\mathrm{C} 6-\mathrm{C} 11-\mathrm{C} 10$
$0.3(5)$
$\mathrm{C} 30-\mathrm{O} 29-\mathrm{C} 27-\mathrm{C} 26$
$-178.0(3)$
$\mathrm{C} 7-\mathrm{C} 8-\mathrm{C} 9-\mathrm{C} 10$
$0.5(5)$

Hydrogen-bond geometry $\left(A,{ }^{\circ}\right)$

$C g 1$ is the centroid of ring $\mathrm{C} 6-\mathrm{C} 11, C g 2$ is the centroid of ring N2/C3-C6/C11 and $C g 3$ is the centroid of ring $\mathrm{C} 17-\mathrm{C} 22$.

\begin{tabular}{lllll}
\hline$D-\mathrm{H} \cdots A$ & $D-\mathrm{H}$ & $\mathrm{H} \cdots A$ & $D \cdots A$ & $D-\mathrm{H} \cdots A$ \\
\hline $\mathrm{C} 16-\mathrm{H} 16 B \cdots \mathrm{O} 12$ & 0.99 & 2.45 & $3.070(4)$ & 120 \\
$\mathrm{C} 18-\mathrm{H} 18 \cdots \mathrm{O} 12$ & 0.95 & 2.57 & $3.352(5)$ & 140 \\
$\mathrm{C} 4-\mathrm{H} 4 \cdots \mathrm{O} 12^{\mathrm{i}}$ & 0.95 & 2.57 & $3.488(4)$ & 163 \\
$\mathrm{C} 14-\mathrm{H} 14 A \cdots C g 2^{\mathrm{ii}}$ & 0.93 & 2.94 & $3.581(4)$ & 127 \\
$\mathrm{C} 14-\mathrm{H} 14 B \cdots C g 1^{\mathrm{ii}}$ & 0.93 & 2.88 & $3.493(4)$ & 125 \\
$\mathrm{C} 24-\mathrm{H} 24 C \cdots C g 1$ & 0.98 & 2.91 & $3.513(5)$ & 121 \\
$\mathrm{C} 32-\mathrm{H} 32 A \cdots C g 3^{\mathrm{iii}}$ & 0.98 & 2.84 & $3.655(5)$ & 141
\end{tabular}

Symmetry codes: (i) $x+1, y, z$; (ii) $-x,-y+2,-z+1$; (iii) $-x+1,-y+1,-z$.

\{ $\eta^{2}$-4-Allyl-2-methoxy-1-[(propan-2-yloxy)carbonylmethoxy]benzene\}chlorido(quinolin-8-olato-

$\left.\kappa^{2} N, O\right)$ platinum(II) (chi9)

Crystal data

$\left[\mathrm{Pt}\left(\mathrm{C}_{9} \mathrm{H}_{6} \mathrm{NO}\right) \mathrm{Cl}\left(\mathrm{C}_{15} \mathrm{H}_{20} \mathrm{O}_{4}\right)\right]$

$M_{r}=639.00$

Triclinic, $P \overline{1}$

$a=9.7858(3) \AA$

$b=11.0447$ (2) $\AA$

$c=11.8117$ (3) $\AA$

$\alpha=85.059(2)^{\circ}$

$\beta=73.685(3)^{\circ}$

$\gamma=71.139(2)^{\circ}$

$V=1159.41(6) \AA^{3}$

\section{Data collection}

Agilent SuperNova Dual Source diffractometer with an Eos detector

Radiation source: SuperNova (Mo) X-ray Source

Mirror monochromator

Detector resolution: 15.9631 pixels $\mathrm{mm}^{-1}$

$\omega$ scans

Absorption correction: multi-scan

(CrysAlis PRO; Agilent, 2013)

\section{Refinement}

Refinement on $F^{2}$

Least-squares matrix: full

$R\left[F^{2}>2 \sigma\left(F^{2}\right)\right]=0.017$

$w R\left(F^{2}\right)=0.041$

$S=1.10$

4738 reflections

292 parameters

0 restraints
$Z=2$

$F(000)=624$

$D_{\mathrm{x}}=1.830 \mathrm{Mg} \mathrm{m}^{-3}$

Mo $K \alpha$ radiation, $\lambda=0.71073 \AA$

Cell parameters from 30804 reflections

$\theta=3.3-29.2^{\circ}$

$\mu=6.20 \mathrm{~mm}^{-1}$

$T=200 \mathrm{~K}$

Block, yellow

$0.3 \times 0.25 \times 0.15 \mathrm{~mm}$

$T_{\min }=0.369, T_{\max }=1.000$

47800 measured reflections

4738 independent reflections

4534 reflections with $I>2 \sigma(I)$

$R_{\text {int }}=0.037$

$\theta_{\max }=26.4^{\circ}, \theta_{\min }=2.7^{\circ}$

$h=-12 \rightarrow 12$

$k=-13 \rightarrow 13$

$l=-14 \rightarrow 14$

Primary atom site location: structure-invariant direct methods

Hydrogen site location: inferred from neighbouring sites

$\mathrm{H}$-atom parameters constrained

$w=1 /\left[\sigma^{2}\left(F_{\mathrm{o}}^{2}\right)+(0.0139 P)^{2}+1.3246 P\right]$

where $P=\left(F_{\mathrm{o}}^{2}+2 F_{\mathrm{c}}^{2}\right) / 3$

$(\Delta / \sigma)_{\max }=0.001$

$\Delta \rho_{\max }=1.46 \mathrm{e} \AA^{-3}$

$\Delta \rho_{\min }=-1.01 \mathrm{e} \AA^{-3}$ 


\section{Special details}

Geometry. All esds (except the esd in the dihedral angle between two 1.s. planes) are estimated using the full covariance matrix. The cell esds are taken into account individually in the estimation of esds in distances, angles and torsion angles; correlations between esds in cell parameters are only used when they are defined by crystal symmetry. An approximate (isotropic) treatment of cell esds is used for estimating esds involving 1.s. planes.

Fractional atomic coordinates and isotropic or equivalent isotropic displacement parameters $\left(\AA^{2}\right)$

\begin{tabular}{|c|c|c|c|c|}
\hline & $x$ & $y$ & $z$ & $U_{\text {iso }} * / U_{\text {eq }}$ \\
\hline $\mathrm{C} 3$ & -0.1859 & 0.5736 & 0.8919 & $0.0312(6)$ \\
\hline H3 & -0.136026 & 0.551246 & 0.952579 & $0.037^{*}$ \\
\hline $\mathrm{C} 4$ & -0.1698 & 0.6780 & 0.8191 & $0.0371(7)$ \\
\hline H4 & -0.109806 & 0.725613 & 0.831437 & $0.044 *$ \\
\hline $\mathrm{C} 5$ & -0.2395 & 0.7118 & 0.7307 & $0.0325(6)$ \\
\hline H5 & -0.228789 & 0.782996 & 0.681875 & $0.039 *$ \\
\hline C6 & $-0.3279(3)$ & $0.6399(3)$ & $0.7125(2)$ & $0.0291(6)$ \\
\hline $\mathrm{C} 7$ & $-0.4021(4)$ & $0.6640(3)$ & $0.6226(3)$ & $0.0375(7)$ \\
\hline $\mathrm{H} 7$ & -0.392972 & 0.730819 & 0.567552 & $0.045^{*}$ \\
\hline $\mathrm{C} 8$ & $-0.4877(4)$ & $0.5894(3)$ & 0.6156 & $0.0428(8)$ \\
\hline H8 & -0.538702 & 0.606963 & 0.555603 & $0.051 *$ \\
\hline C9 & $-0.5029(4)$ & $0.4884(3)$ & $0.6935(3)$ & $0.0391(7)$ \\
\hline H9 & -0.563451 & 0.439284 & 0.685632 & $0.047 *$ \\
\hline $\mathrm{C} 10$ & -0.4298 & $0.4602(3)$ & $0.7819(2)$ & $0.0283(6)$ \\
\hline C11 & $-0.3416(3)$ & $0.5375(2)$ & $0.7905(2)$ & $0.0241(5)$ \\
\hline C14 & $-0.3857(4)$ & $0.2014(3)$ & $1.0626(3)$ & $0.0399(7)$ \\
\hline $\mathrm{H} 14 \mathrm{~A}$ & -0.378315 & 0.190373 & 1.144981 & $0.048^{*}$ \\
\hline H14B & -0.482399 & 0.198555 & 1.054109 & $0.048^{*}$ \\
\hline $\mathrm{C} 15$ & $-0.2573(4)$ & $0.1376(3)$ & $0.9756(3)$ & $0.0346(7)$ \\
\hline H15 & -0.168809 & 0.090147 & 1.005924 & $0.042 *$ \\
\hline $\mathrm{C} 16$ & -0.2630 & $0.0802(3)$ & $0.8671(3)$ & $0.0365(7)$ \\
\hline H16A & -0.351713 & 0.134864 & 0.842030 & $0.044 *$ \\
\hline H16B & -0.276076 & -0.005014 & 0.886936 & $0.044^{*}$ \\
\hline C17 & -0.1239 & $0.0657(3)$ & $0.7646(3)$ & $0.0311(6)$ \\
\hline C18 & $-0.1177(3)$ & $0.1623(3)$ & $0.6802(3)$ & $0.0325(6)$ \\
\hline H18 & -0.201221 & 0.237708 & 0.687036 & $0.039 *$ \\
\hline C19 & $0.0092(3)$ & $0.1488(3)$ & $0.5867(2)$ & $0.0300(6)$ \\
\hline $\mathrm{C} 20$ & 0.1327 & $0.0372(3)$ & 0.5753 & $0.0289(6)$ \\
\hline $\mathrm{C} 21$ & $0.1276(3)$ & -0.0571 & 0.6586 & $0.0342(6)$ \\
\hline $\mathrm{H} 21$ & 0.210996 & -0.132599 & 0.652078 & $0.041 *$ \\
\hline $\mathrm{C} 22$ & $-0.0004(4)$ & -0.0419 & 0.7529 & $0.0354(7)$ \\
\hline $\mathrm{H} 22$ & -0.002276 & -0.107384 & 0.810518 & $0.042 *$ \\
\hline $\mathrm{C} 24$ & -0.0978 (4) & $0.3521(3)$ & 0.5056 & $0.0555(10)$ \\
\hline $\mathrm{H} 24 \mathrm{~A}$ & -0.073160 & 0.405287 & 0.436914 & $0.083 *$ \\
\hline $\mathrm{H} 24 \mathrm{~B}$ & -0.117973 & 0.399543 & 0.577958 & $0.083^{*}$ \\
\hline $\mathrm{H} 24 \mathrm{C}$ & -0.186798 & 0.329817 & 0.505151 & $0.083^{*}$ \\
\hline $\mathrm{C} 26$ & $0.3687(3)$ & $-0.0846(3)$ & $0.4582(3)$ & $0.0316(6)$ \\
\hline $\mathrm{H} 26 \mathrm{~A}$ & 0.329614 & -0.150676 & 0.439842 & $0.038^{*}$ \\
\hline H26B & 0.404777 & -0.111460 & 0.529549 & $0.038^{*}$ \\
\hline
\end{tabular}




$\begin{array}{lllll}\text { C27 } & 0.4958(3) & -0.0715(3) & 0.3562(3) & 0.0294(6) \\ \text { C30 } & 0.7357(3) & -0.1960(3) & 0.2374(3) & 0.0379(7) \\ \text { H30 } & 0.772178 & -0.124178 & 0.248467 & 0.046^{*} \\ \text { C31 } & 0.7087(4) & -0.1866(4) & 0.1172(3) & 0.0512(9) \\ \text { H31A } & 0.803987 & -0.198775 & 0.056507 & 0.077^{*} \\ \text { H31B } & 0.639097 & -0.102057 & 0.108053 & 0.077^{*} \\ \text { H31C } & 0.665597 & -0.252856 & 0.108640 & 0.077^{*} \\ \text { C32 } & 0.8458(4) & -0.3219(3) & 0.2587(4) & 0.0555(10) \\ \text { H32A } & 0.815462 & -0.392474 & 0.240074 & 0.083^{*} \\ \text { H32B } & 0.847282 & -0.327029 & 0.341567 & 0.083^{*} \\ \text { H32C } & 0.946136 & -0.327789 & 0.208108 & 0.083^{*} \\ \text { C113 } & -0.14543(9) & 0.33203(8) & 1.08003(7) & 0.04446(19) \\ \text { N2 } & -0.2692(2) & 0.5055(2) & 0.87781(19) & 0.0254(5) \\ \text { O12 } & -0.4363(2) & 0.36373(18) & 0.85739(18) & 0.0314(4) \\ \text { O23 } & 0.0252(2) & 0.23816(19) & 0.50069(18) & 0.0411(5) \\ \text { O25 } & 0.2535(2) & 0.03400(18) & 0.47921(18) & 0.0354(5) \\ \text { O28 } & 0.5090(3) & 0.0266(2) & 0.3106(2) & 0.0453(6) \\ \text { O29 } & 0.5949(2) & -0.18764(18) & 0.32815(18) & 0.0323(4) \\ \text { Pt1 } & -0.29907(2) & 0.34304(2) & 0.96161(2) & 0.02646(4)\end{array}$

Atomic displacement parameters $\left(\AA^{2}\right)$

\begin{tabular}{lllllll}
\hline & $U^{11}$ & $U^{22}$ & $U^{33}$ & $U^{12}$ & $U^{13}$ & $U^{23}$ \\
\hline C3 & $0.0306(15)$ & $0.0285(14)$ & $0.0353(16)$ & $-0.0075(12)$ & $-0.0114(12)$ & $-0.0024(12)$ \\
C4 & $0.0318(16)$ & $0.0302(15)$ & $0.0499(19)$ & $-0.0122(13)$ & $-0.0086(14)$ & $-0.0014(13)$ \\
C5 & $0.0315(15)$ & $0.0225(14)$ & $0.0339(16)$ & $-0.0042(12)$ & $0.0009(12)$ & $0.0019(11)$ \\
C6 & $0.0298(14)$ & $0.0228(13)$ & $0.0235(13)$ & $0.0014(11)$ & $-0.0005(11)$ & $-0.0017(10)$ \\
C7 & $0.0478(19)$ & $0.0263(15)$ & $0.0299(15)$ & $0.0003(13)$ & $-0.0120(14)$ & $0.0033(12)$ \\
C8 & $0.050(2)$ & $0.0377(17)$ & $0.0386(18)$ & $0.0019(15)$ & $-0.0258(16)$ & $-0.0024(14)$ \\
C9 & $0.0384(17)$ & $0.0368(17)$ & $0.0458(19)$ & $-0.0071(14)$ & $-0.0209(15)$ & $-0.0047(14)$ \\
C10 & $0.0250(14)$ & $0.0243(14)$ & $0.0309(15)$ & $-0.0011(11)$ & $-0.0071(11)$ & $-0.0020(11)$ \\
C11 & $0.0217(13)$ & $0.0198(12)$ & $0.0241(13)$ & $0.0002(10)$ & $-0.0024(10)$ & $-0.0034(10)$ \\
C14 & $0.0438(18)$ & $0.0311(16)$ & $0.0331(16)$ & $-0.0125(14)$ & $0.0061(14)$ & $0.0092(13)$ \\
C15 & $0.0405(17)$ & $0.0235(14)$ & $0.0291(15)$ & $-0.0068(12)$ & $0.0012(13)$ & $0.0080(11)$ \\
C16 & $0.0381(17)$ & $0.0280(15)$ & $0.0395(17)$ & $-0.0132(13)$ & $-0.0015(14)$ & $0.0031(12)$ \\
C17 & $0.0365(16)$ & $0.0249(14)$ & $0.0298(15)$ & $-0.0122(12)$ & $-0.0025(12)$ & $-0.0010(11)$ \\
C18 & $0.0339(16)$ & $0.0245(14)$ & $0.0315(15)$ & $-0.0041(12)$ & $-0.0025(12)$ & $-0.0013(11)$ \\
C19 & $0.0344(15)$ & $0.0239(14)$ & $0.0250(14)$ & $-0.0040(12)$ & $-0.0040(12)$ & $0.0008(11)$ \\
C20 & $0.0315(15)$ & $0.0267(14)$ & $0.0236(14)$ & $-0.0054(12)$ & $-0.0038(11)$ & $-0.0014(11)$ \\
C21 & $0.0393(17)$ & $0.0234(14)$ & $0.0335(16)$ & $-0.0037(12)$ & $-0.0072(13)$ & $0.0013(12)$ \\
C22 & $0.0471(18)$ & $0.0239(14)$ & $0.0315(15)$ & $-0.0127(13)$ & $-0.0044(13)$ & $0.0046(12)$ \\
C24 & $0.047(2)$ & $0.0341(18)$ & $0.055(2)$ & $0.0089(15)$ & $0.0041(17)$ & $0.0179(16)$ \\
C26 & $0.0308(15)$ & $0.0239(14)$ & $0.0321(15)$ & $-0.0009(12)$ & $-0.0045(12)$ & $-0.0012(11)$ \\
C27 & $0.0280(14)$ & $0.0255(14)$ & $0.0327(15)$ & $-0.0040(11)$ & $-0.0090(12)$ & $-0.0045(12)$ \\
C30 & $0.0269(15)$ & $0.0352(16)$ & $0.0465(18)$ & $-0.0092(13)$ & $0.0004(13)$ & $-0.0089(14)$ \\
C31 & $0.043(2)$ & $0.063(2)$ & $0.0398(19)$ & $-0.0156(17)$ & $0.0024(15)$ & $-0.0077(17)$ \\
C32 & $0.0304(18)$ & $0.046(2)$ & $0.079(3)$ & $-0.0011(15)$ & $-0.0075(18)$ & $-0.0070(19)$ \\
C113 & $0.0453(4)$ & $0.0485(5)$ & $0.0394(4)$ & $-0.0074(4)$ & $-0.0220(4)$ & $0.0084(3)$ \\
& & & & & &
\end{tabular}




\begin{tabular}{lllllll}
$\mathrm{N} 2$ & $0.0240(11)$ & $0.0230(11)$ & $0.0254(11)$ & $-0.0037(9)$ & $-0.0051(9)$ & $-0.0001(9)$ \\
$\mathrm{O} 12$ & $0.0292(10)$ & $0.0289(10)$ & $0.0366(11)$ & $-0.0113(8)$ & $-0.0084(9)$ & $0.0047(8)$ \\
$\mathrm{O} 23$ & $0.0392(12)$ & $0.0298(11)$ & $0.0312(11)$ & $0.0048(9)$ & $0.0052(9)$ & $0.0103(9)$ \\
$\mathrm{O} 25$ & $0.0327(11)$ & $0.0249(10)$ & $0.0319(11)$ & $0.0027(8)$ & $0.0027(9)$ & $0.0035(8)$ \\
O28 & $0.0419(13)$ & $0.0243(11)$ & $0.0556(15)$ & $-0.0047(9)$ & $0.0018(11)$ & $0.0018(10)$ \\
O29 & $0.0286(10)$ & $0.0247(10)$ & $0.0363(11)$ & $-0.0037(8)$ & $-0.0018(9)$ & $-0.0033(8)$ \\
Pt1 & $0.02589(6)$ & $0.02385(6)$ & $0.02392(6)$ & $-0.00394(4)$ & $-0.00313(4)$ & $0.00299(4)$ \\
\hline
\end{tabular}

Geometric parameters $\left(A,{ }^{\circ}\right)$

\begin{tabular}{|c|c|c|c|}
\hline $\mathrm{C} 3-\mathrm{H} 3$ & 0.9500 & $\mathrm{C} 18-\mathrm{C} 19$ & $1.387(4)$ \\
\hline $\mathrm{C} 3-\mathrm{C} 4$ & $1.401(4)$ & $\mathrm{C} 19-\mathrm{C} 20$ & $1.404(4)$ \\
\hline $\mathrm{C} 3-\mathrm{N} 2$ & $1.323(3)$ & $\mathrm{C} 19-\mathrm{O} 23$ & $1.367(3)$ \\
\hline $\mathrm{C} 4-\mathrm{H} 4$ & 0.9500 & $\mathrm{C} 20-\mathrm{C} 21$ & $1.374(4)$ \\
\hline $\mathrm{C} 4-\mathrm{C} 5$ & $1.365(4)$ & $\mathrm{C} 20-\mathrm{O} 25$ & $1.383(3)$ \\
\hline $\mathrm{C} 5-\mathrm{H} 5$ & 0.9500 & $\mathrm{C} 21-\mathrm{H} 21$ & 0.9500 \\
\hline $\mathrm{C} 5-\mathrm{C} 6$ & $1.416(4)$ & $\mathrm{C} 21-\mathrm{C} 22$ & $1.397(4)$ \\
\hline $\mathrm{C} 6-\mathrm{C} 7$ & $1.410(4)$ & $\mathrm{C} 22-\mathrm{H} 22$ & 0.9500 \\
\hline $\mathrm{C} 6-\mathrm{C} 11$ & $1.413(4)$ & $\mathrm{C} 24-\mathrm{H} 24 \mathrm{~A}$ & 0.9800 \\
\hline $\mathrm{C} 7-\mathrm{H} 7$ & 0.9500 & $\mathrm{C} 24-\mathrm{H} 24 \mathrm{~B}$ & 0.9800 \\
\hline $\mathrm{C} 7-\mathrm{C} 8$ & $1.372(5)$ & $\mathrm{C} 24-\mathrm{H} 24 \mathrm{C}$ & 0.9800 \\
\hline $\mathrm{C} 8-\mathrm{H} 8$ & 0.9500 & $\mathrm{C} 24-\mathrm{O} 23$ & $1.424(4)$ \\
\hline $\mathrm{C} 8-\mathrm{C} 9$ & $1.403(5)$ & $\mathrm{C} 26-\mathrm{H} 26 \mathrm{~A}$ & 0.9900 \\
\hline $\mathrm{C} 9-\mathrm{H} 9$ & 0.9500 & $\mathrm{C} 26-\mathrm{H} 26 \mathrm{~B}$ & 0.9900 \\
\hline $\mathrm{C} 9-\mathrm{C} 10$ & $1.385(4)$ & $\mathrm{C} 26-\mathrm{C} 27$ & $1.505(4)$ \\
\hline $\mathrm{C} 10-\mathrm{C} 11$ & $1.423(4)$ & $\mathrm{C} 26-\mathrm{O} 25$ & $1.411(3)$ \\
\hline $\mathrm{C} 10-\mathrm{O} 12$ & $1.335(3)$ & $\mathrm{C} 27-\mathrm{O} 28$ & $1.196(3)$ \\
\hline $\mathrm{C} 11-\mathrm{N} 2$ & $1.370(3)$ & $\mathrm{C} 27-\mathrm{O} 29$ & $1.336(3)$ \\
\hline $\mathrm{C} 14-\mathrm{H} 14 \mathrm{~A}$ & 0.9900 & $\mathrm{C} 30-\mathrm{H} 30$ & 1.0000 \\
\hline $\mathrm{C} 14-\mathrm{H} 14 \mathrm{~B}$ & 0.9900 & $\mathrm{C} 30-\mathrm{C} 31$ & $1.505(5)$ \\
\hline $\mathrm{C} 14-\mathrm{C} 15$ & $1.400(4)$ & $\mathrm{C} 30-\mathrm{C} 32$ & $1.510(5)$ \\
\hline $\mathrm{C} 14-\mathrm{Pt} 1$ & $2.134(3)$ & $\mathrm{C} 30-\mathrm{O} 29$ & $1.470(3)$ \\
\hline C15-H15 & 1.0000 & $\mathrm{C} 31-\mathrm{H} 31 \mathrm{~A}$ & 0.9800 \\
\hline $\mathrm{C} 15-\mathrm{C} 16$ & $1.501(4)$ & $\mathrm{C} 31-\mathrm{H} 31 \mathrm{~B}$ & 0.9800 \\
\hline C15-Pt1 & $2.172(3)$ & $\mathrm{C} 31-\mathrm{H} 31 \mathrm{C}$ & 0.9800 \\
\hline $\mathrm{C} 16-\mathrm{H} 16 \mathrm{~A}$ & 0.9900 & $\mathrm{C} 32-\mathrm{H} 32 \mathrm{~A}$ & 0.9800 \\
\hline C16-H16B & 0.9900 & $\mathrm{C} 32-\mathrm{H} 32 \mathrm{~B}$ & 0.9800 \\
\hline $\mathrm{C} 16-\mathrm{C} 17$ & $1.520(4)$ & $\mathrm{C} 32-\mathrm{H} 32 \mathrm{C}$ & 0.9800 \\
\hline $\mathrm{C} 17-\mathrm{C} 18$ & $1.400(4)$ & $\mathrm{Cl13}-\mathrm{Pt} 1$ & $2.2947(8)$ \\
\hline $\mathrm{C} 17-\mathrm{C} 22$ & $1.378(4)$ & N2-Pt1 & $2.039(2)$ \\
\hline $\mathrm{C} 18-\mathrm{H} 18$ & 0.9500 & $\mathrm{O} 12-\mathrm{Pt} 1$ & 2.0135 (19) \\
\hline $\mathrm{C} 4-\mathrm{C} 3-\mathrm{H} 3$ & 119.3 & $\mathrm{C} 20-\mathrm{C} 21-\mathrm{H} 21$ & 120.1 \\
\hline $\mathrm{N} 2-\mathrm{C} 3-\mathrm{H} 3$ & 119.3 & $\mathrm{C} 20-\mathrm{C} 21-\mathrm{C} 22$ & $119.9(3)$ \\
\hline $\mathrm{N} 2-\mathrm{C} 3-\mathrm{C} 4$ & $121.5(3)$ & $\mathrm{C} 22-\mathrm{C} 21-\mathrm{H} 21$ & 120.1 \\
\hline $\mathrm{C} 3-\mathrm{C} 4-\mathrm{H} 4$ & 119.7 & $\mathrm{C} 17-\mathrm{C} 22-\mathrm{C} 21$ & $121.6(3)$ \\
\hline $\mathrm{C} 5-\mathrm{C} 4-\mathrm{C} 3$ & $120.5(3)$ & $\mathrm{C} 17-\mathrm{C} 22-\mathrm{H} 22$ & 119.2 \\
\hline $\mathrm{C} 5-\mathrm{C} 4-\mathrm{H} 4$ & 119.7 & $\mathrm{C} 21-\mathrm{C} 22-\mathrm{H} 22$ & 119.2 \\
\hline
\end{tabular}




\begin{tabular}{|c|c|c|c|}
\hline $\mathrm{C} 4-\mathrm{C} 5-\mathrm{H} 5$ & 120.3 & $\mathrm{H} 24 \mathrm{~A}-\mathrm{C} 24-\mathrm{H} 24 \mathrm{~B}$ & 109.5 \\
\hline $\mathrm{C} 4-\mathrm{C} 5-\mathrm{C} 6$ & $119.4(3)$ & $\mathrm{H} 24 \mathrm{~A}-\mathrm{C} 24-\mathrm{H} 24 \mathrm{C}$ & 109.5 \\
\hline $\mathrm{C} 6-\mathrm{C} 5-\mathrm{H} 5$ & 120.3 & $\mathrm{H} 24 \mathrm{~B}-\mathrm{C} 24-\mathrm{H} 24 \mathrm{C}$ & 109.5 \\
\hline $\mathrm{C} 7-\mathrm{C} 6-\mathrm{C} 5$ & $124.4(3)$ & $\mathrm{O} 23-\mathrm{C} 24-\mathrm{H} 24 \mathrm{~A}$ & 109.5 \\
\hline $\mathrm{C} 7-\mathrm{C} 6-\mathrm{C} 11$ & $118.5(3)$ & $\mathrm{O} 23-\mathrm{C} 24-\mathrm{H} 24 \mathrm{~B}$ & 109.5 \\
\hline $\mathrm{C} 11-\mathrm{C} 6-\mathrm{C} 5$ & $117.1(3)$ & $\mathrm{O} 23-\mathrm{C} 24-\mathrm{H} 24 \mathrm{C}$ & 109.5 \\
\hline $\mathrm{C} 6-\mathrm{C} 7-\mathrm{H} 7$ & 120.5 & $\mathrm{H} 26 \mathrm{~A}-\mathrm{C} 26-\mathrm{H} 26 \mathrm{~B}$ & 108.3 \\
\hline $\mathrm{C} 8-\mathrm{C} 7-\mathrm{C} 6$ & $119.0(3)$ & $\mathrm{C} 27-\mathrm{C} 26-\mathrm{H} 26 \mathrm{~A}$ & 109.8 \\
\hline $\mathrm{C} 8-\mathrm{C} 7-\mathrm{H} 7$ & 120.5 & $\mathrm{C} 27-\mathrm{C} 26-\mathrm{H} 26 \mathrm{~B}$ & 109.8 \\
\hline $\mathrm{C} 7-\mathrm{C} 8-\mathrm{H} 8$ & 118.7 & $\mathrm{O} 25-\mathrm{C} 26-\mathrm{H} 26 \mathrm{~A}$ & 109.8 \\
\hline $\mathrm{C} 7-\mathrm{C} 8-\mathrm{C} 9$ & $122.7(3)$ & $\mathrm{O} 25-\mathrm{C} 26-\mathrm{H} 26 \mathrm{~B}$ & 109.8 \\
\hline $\mathrm{C} 9-\mathrm{C} 8-\mathrm{H} 8$ & 118.7 & $\mathrm{O} 25-\mathrm{C} 26-\mathrm{C} 27$ & $109.3(2)$ \\
\hline $\mathrm{C} 8-\mathrm{C} 9-\mathrm{H} 9$ & 119.9 & $\mathrm{O} 28-\mathrm{C} 27-\mathrm{C} 26$ & $125.9(3)$ \\
\hline $\mathrm{C} 10-\mathrm{C} 9-\mathrm{C} 8$ & $120.2(3)$ & $\mathrm{O} 28-\mathrm{C} 27-\mathrm{O} 29$ & $125.6(3)$ \\
\hline $\mathrm{C} 10-\mathrm{C} 9-\mathrm{H} 9$ & 119.9 & $\mathrm{O} 29-\mathrm{C} 27-\mathrm{C} 26$ & $108.4(2)$ \\
\hline $\mathrm{C} 9-\mathrm{C} 10-\mathrm{C} 11$ & $117.6(3)$ & $\mathrm{C} 31-\mathrm{C} 30-\mathrm{H} 30$ & 109.5 \\
\hline $\mathrm{O} 12-\mathrm{C} 10-\mathrm{C} 9$ & $123.4(3)$ & $\mathrm{C} 31-\mathrm{C} 30-\mathrm{C} 32$ & $113.5(3)$ \\
\hline $\mathrm{O} 12-\mathrm{C} 10-\mathrm{C} 11$ & $118.9(2)$ & $\mathrm{C} 32-\mathrm{C} 30-\mathrm{H} 30$ & 109.5 \\
\hline $\mathrm{C} 6-\mathrm{C} 11-\mathrm{C} 10$ & $122.0(2)$ & $\mathrm{O} 29-\mathrm{C} 30-\mathrm{H} 30$ & 109.5 \\
\hline $\mathrm{N} 2-\mathrm{C} 11-\mathrm{C} 6$ & $122.0(2)$ & $\mathrm{O} 29-\mathrm{C} 30-\mathrm{C} 31$ & $109.4(3)$ \\
\hline $\mathrm{N} 2-\mathrm{C} 11-\mathrm{C} 10$ & $116.0(2)$ & $\mathrm{O} 29-\mathrm{C} 30-\mathrm{C} 32$ & $105.4(3)$ \\
\hline $\mathrm{H} 14 \mathrm{~A}-\mathrm{C} 14-\mathrm{H} 14 \mathrm{~B}$ & 113.3 & $\mathrm{C} 30-\mathrm{C} 31-\mathrm{H} 31 \mathrm{~A}$ & 109.5 \\
\hline $\mathrm{C} 15-\mathrm{C} 14-\mathrm{H} 14 \mathrm{~A}$ & 116.3 & $\mathrm{C} 30-\mathrm{C} 31-\mathrm{H} 31 \mathrm{~B}$ & 109.5 \\
\hline $\mathrm{C} 15-\mathrm{C} 14-\mathrm{H} 14 \mathrm{~B}$ & 116.3 & $\mathrm{C} 30-\mathrm{C} 31-\mathrm{H} 31 \mathrm{C}$ & 109.5 \\
\hline $\mathrm{C} 15-\mathrm{C} 14-\mathrm{Pt} 1$ & $72.51(16)$ & $\mathrm{H} 31 \mathrm{~A}-\mathrm{C} 31-\mathrm{H} 31 \mathrm{~B}$ & 109.5 \\
\hline $\mathrm{Pt} 1-\mathrm{C} 14-\mathrm{H} 14 \mathrm{~A}$ & 116.3 & $\mathrm{H} 31 \mathrm{~A}-\mathrm{C} 31-\mathrm{H} 31 \mathrm{C}$ & 109.5 \\
\hline $\mathrm{Pt} 1-\mathrm{C} 14-\mathrm{H} 14 \mathrm{~B}$ & 116.3 & $\mathrm{H} 31 \mathrm{~B}-\mathrm{C} 31-\mathrm{H} 31 \mathrm{C}$ & 109.5 \\
\hline $\mathrm{C} 14-\mathrm{C} 15-\mathrm{H} 15$ & 114.5 & $\mathrm{C} 30-\mathrm{C} 32-\mathrm{H} 32 \mathrm{~A}$ & 109.5 \\
\hline $\mathrm{C} 14-\mathrm{C} 15-\mathrm{C} 16$ & $123.1(3)$ & $\mathrm{C} 30-\mathrm{C} 32-\mathrm{H} 32 \mathrm{~B}$ & 109.5 \\
\hline $\mathrm{C} 14-\mathrm{C} 15-\mathrm{Pt} 1$ & $69.57(16)$ & $\mathrm{C} 30-\mathrm{C} 32-\mathrm{H} 32 \mathrm{C}$ & 109.5 \\
\hline $\mathrm{C} 16-\mathrm{C} 15-\mathrm{H} 15$ & 114.5 & $\mathrm{H} 32 \mathrm{~A}-\mathrm{C} 32-\mathrm{H} 32 \mathrm{~B}$ & 109.5 \\
\hline $\mathrm{C} 16-\mathrm{C} 15-\mathrm{Pt} 1$ & $112.57(19)$ & $\mathrm{H} 32 \mathrm{~A}-\mathrm{C} 32-\mathrm{H} 32 \mathrm{C}$ & 109.5 \\
\hline $\mathrm{Pt} 1-\mathrm{C} 15-\mathrm{H} 15$ & 114.5 & $\mathrm{H} 32 \mathrm{~B}-\mathrm{C} 32-\mathrm{H} 32 \mathrm{C}$ & 109.5 \\
\hline $\mathrm{C} 15-\mathrm{C} 16-\mathrm{H} 16 \mathrm{~A}$ & 108.8 & $\mathrm{C} 3-\mathrm{N} 2-\mathrm{C} 11$ & $119.5(2)$ \\
\hline $\mathrm{C} 15-\mathrm{C} 16-\mathrm{H} 16 \mathrm{~B}$ & 108.8 & $\mathrm{C} 3-\mathrm{N} 2-\mathrm{Pt} 1$ & $129.50(19)$ \\
\hline $\mathrm{C} 15-\mathrm{C} 16-\mathrm{C} 17$ & $113.6(3)$ & $\mathrm{C} 11-\mathrm{N} 2-\mathrm{Pt} 1$ & $110.82(17)$ \\
\hline $\mathrm{H} 16 \mathrm{~A}-\mathrm{C} 16-\mathrm{H} 16 \mathrm{~B}$ & 107.7 & $\mathrm{C} 10-\mathrm{O} 12-\mathrm{Pt} 1$ & $111.41(16)$ \\
\hline $\mathrm{C} 17-\mathrm{C} 16-\mathrm{H} 16 \mathrm{~A}$ & 108.8 & $\mathrm{C} 19-\mathrm{O} 23-\mathrm{C} 24$ & $118.1(2)$ \\
\hline $\mathrm{C} 17-\mathrm{C} 16-\mathrm{H} 16 \mathrm{~B}$ & 108.8 & $\mathrm{C} 20-\mathrm{O} 25-\mathrm{C} 26$ & $115.3(2)$ \\
\hline $\mathrm{C} 18-\mathrm{C} 17-\mathrm{C} 16$ & $120.7(3)$ & $\mathrm{C} 27-\mathrm{O} 29-\mathrm{C} 30$ & $117.6(2)$ \\
\hline $\mathrm{C} 22-\mathrm{C} 17-\mathrm{C} 16$ & $121.0(3)$ & $\mathrm{C} 14-\mathrm{Pt} 1-\mathrm{C} 15$ & $37.92(11)$ \\
\hline $\mathrm{C} 22-\mathrm{C} 17-\mathrm{C} 18$ & $118.3(3)$ & $\mathrm{C} 14-\mathrm{Pt} 1-\mathrm{Cl13}$ & $92.02(10)$ \\
\hline $\mathrm{C} 17-\mathrm{C} 18-\mathrm{H} 18$ & 119.7 & $\mathrm{C} 15-\mathrm{Pt} 1-\mathrm{Cl13}$ & $90.47(9)$ \\
\hline $\mathrm{C} 19-\mathrm{C} 18-\mathrm{C} 17$ & $120.6(3)$ & N2-Pt1-C14 & $166.07(11)$ \\
\hline $\mathrm{C} 19-\mathrm{C} 18-\mathrm{H} 18$ & 119.7 & $\mathrm{~N} 2-\mathrm{Pt} 1-\mathrm{C} 15$ & $153.86(10)$ \\
\hline $\mathrm{C} 18-\mathrm{C} 19-\mathrm{C} 20$ & $120.2(3)$ & $\mathrm{N} 2-\mathrm{Pt} 1-\mathrm{Cl} 13$ & $94.65(7)$ \\
\hline $\mathrm{O} 23-\mathrm{C} 19-\mathrm{C} 18$ & $124.5(3)$ & $\mathrm{O} 12-\mathrm{Pt} 1-\mathrm{C} 14$ & $90.51(11)$ \\
\hline $\mathrm{O} 23-\mathrm{C} 19-\mathrm{C} 20$ & $115.3(2)$ & $\mathrm{O} 12-\mathrm{Pt} 1-\mathrm{C} 15$ & $92.84(10)$ \\
\hline
\end{tabular}




\begin{tabular}{|c|c|c|c|}
\hline $\mathrm{C} 21-\mathrm{C} 20-\mathrm{C} 19$ & $119.4(3)$ & $\mathrm{O} 12-\mathrm{Pt} 1-\mathrm{C} 113$ & $176.69(6)$ \\
\hline $\mathrm{C} 21-\mathrm{C} 20-\mathrm{O} 25$ & $125.2(3)$ & $\mathrm{O} 12-\mathrm{Pt} 1-\mathrm{N} 2$ & $82.43(8)$ \\
\hline $\mathrm{O} 25-\mathrm{C} 20-\mathrm{C} 19$ & $115.4(2)$ & & \\
\hline $\mathrm{C} 3-\mathrm{C} 4-\mathrm{C} 5-\mathrm{C} 6$ & $-0.4(4)$ & $\mathrm{C} 17-\mathrm{C} 18-\mathrm{C} 19-\mathrm{C} 20$ & $0.5(4)$ \\
\hline $\mathrm{C} 4-\mathrm{C} 3-\mathrm{N} 2-\mathrm{C} 11$ & $-0.1(4)$ & $\mathrm{C} 17-\mathrm{C} 18-\mathrm{C} 19-\mathrm{O} 23$ & $-179.8(3)$ \\
\hline $\mathrm{C} 4-\mathrm{C} 3-\mathrm{N} 2-\mathrm{Pt} 1$ & $174.8(2)$ & $\mathrm{C} 18-\mathrm{C} 17-\mathrm{C} 22-\mathrm{C} 21$ & $-1.3(4)$ \\
\hline $\mathrm{C} 4-\mathrm{C} 5-\mathrm{C} 6-\mathrm{C} 7$ & $-178.5(3)$ & $\mathrm{C} 18-\mathrm{C} 19-\mathrm{C} 20-\mathrm{C} 21$ & $-1.2(4)$ \\
\hline $\mathrm{C} 4-\mathrm{C} 5-\mathrm{C} 6-\mathrm{C} 11$ & $1.5(4)$ & $\mathrm{C} 18-\mathrm{C} 19-\mathrm{C} 20-\mathrm{O} 25$ & $-179.7(3)$ \\
\hline $\mathrm{C} 5-\mathrm{C} 6-\mathrm{C} 7-\mathrm{C} 8$ & $-178.4(3)$ & $\mathrm{C} 18-\mathrm{C} 19-\mathrm{O} 23-\mathrm{C} 24$ & $-1.3(5)$ \\
\hline $\mathrm{C} 5-\mathrm{C} 6-\mathrm{C} 11-\mathrm{C} 10$ & $178.8(2)$ & $\mathrm{C} 19-\mathrm{C} 20-\mathrm{C} 21-\mathrm{C} 22$ & $0.6(4)$ \\
\hline $\mathrm{C} 5-\mathrm{C} 6-\mathrm{C} 11-\mathrm{N} 2$ & $-2.1(4)$ & $\mathrm{C} 19-\mathrm{C} 20-\mathrm{O} 25-\mathrm{C} 26$ & $-171.4(2)$ \\
\hline $\mathrm{C} 6-\mathrm{C} 7-\mathrm{C} 8-\mathrm{C} 9$ & $-1.0(5)$ & $\mathrm{C} 20-\mathrm{C} 19-\mathrm{O} 23-\mathrm{C} 24$ & $178.4(3)$ \\
\hline $\mathrm{C} 6-\mathrm{C} 11-\mathrm{N} 2-\mathrm{C} 3$ & $1.3(4)$ & $\mathrm{C} 20-\mathrm{C} 21-\mathrm{C} 22-\mathrm{C} 17$ & $0.7(5)$ \\
\hline $\mathrm{C} 6-\mathrm{C} 11-\mathrm{N} 2-\mathrm{Pt} 1$ & $-174.45(19)$ & $\mathrm{C} 21-\mathrm{C} 20-\mathrm{O} 25-\mathrm{C} 26$ & $10.1(4)$ \\
\hline $\mathrm{C} 7-\mathrm{C} 6-\mathrm{C} 11-\mathrm{C} 10$ & $-1.2(4)$ & $\mathrm{C} 22-\mathrm{C} 17-\mathrm{C} 18-\mathrm{C} 19$ & $0.7(4)$ \\
\hline $\mathrm{C} 7-\mathrm{C} 6-\mathrm{C} 11-\mathrm{N} 2$ & $178.0(2)$ & $\mathrm{C} 26-\mathrm{C} 27-\mathrm{O} 29-\mathrm{C} 30$ & $-174.5(2)$ \\
\hline $\mathrm{C} 7-\mathrm{C} 8-\mathrm{C} 9-\mathrm{C} 10$ & $-0.1(5)$ & $\mathrm{C} 27-\mathrm{C} 26-\mathrm{O} 25-\mathrm{C} 20$ & $-176.6(2)$ \\
\hline $\mathrm{C} 8-\mathrm{C} 9-\mathrm{C} 10-\mathrm{C} 11$ & $0.5(4)$ & $\mathrm{C} 31-\mathrm{C} 30-\mathrm{O} 29-\mathrm{C} 27$ & $-79.9(3)$ \\
\hline $\mathrm{C} 8-\mathrm{C} 9-\mathrm{C} 10-\mathrm{O} 12$ & $-178.4(3)$ & $\mathrm{C} 32-\mathrm{C} 30-\mathrm{O} 29-\mathrm{C} 27$ & $157.7(3)$ \\
\hline $\mathrm{C} 9-\mathrm{C} 10-\mathrm{C} 11-\mathrm{C} 6$ & $0.1(4)$ & $\mathrm{N} 2-\mathrm{C} 3-\mathrm{C} 4-\mathrm{C} 5$ & $-0.4(5)$ \\
\hline $\mathrm{C} 9-\mathrm{C} 10-\mathrm{C} 11-\mathrm{N} 2$ & $-179.1(2)$ & $\mathrm{O} 12-\mathrm{C} 10-\mathrm{C} 11-\mathrm{C} 6$ & $179.1(2)$ \\
\hline $\mathrm{C} 9-\mathrm{C} 10-\mathrm{O} 12-\mathrm{Pt} 1$ & $174.3(2)$ & $\mathrm{O} 12-\mathrm{C} 10-\mathrm{C} 11-\mathrm{N} 2$ & $-0.1(4)$ \\
\hline $\mathrm{C} 10-\mathrm{C} 11-\mathrm{N} 2-\mathrm{C} 3$ & $-179.5(2)$ & $\mathrm{O} 23-\mathrm{C} 19-\mathrm{C} 20-\mathrm{C} 21$ & $179.1(3)$ \\
\hline $\mathrm{C} 10-\mathrm{C} 11-\mathrm{N} 2-\mathrm{Pt} 1$ & $4.7(3)$ & $\mathrm{O} 23-\mathrm{C} 19-\mathrm{C} 20-\mathrm{O} 25$ & $0.5(4)$ \\
\hline $\mathrm{C} 11-\mathrm{C} 6-\mathrm{C} 7-\mathrm{C} 8$ & $1.6(4)$ & $\mathrm{O} 25-\mathrm{C} 20-\mathrm{C} 21-\mathrm{C} 22$ & $179.0(3)$ \\
\hline $\mathrm{C} 11-\mathrm{C} 10-\mathrm{O} 12-\mathrm{Pt} 1$ & $-4.7(3)$ & $\mathrm{O} 25-\mathrm{C} 26-\mathrm{C} 27-\mathrm{O} 28$ & $10.2(4)$ \\
\hline $\mathrm{C} 14-\mathrm{C} 15-\mathrm{C} 16-\mathrm{C} 17$ & $156.2(3)$ & $\mathrm{O} 25-\mathrm{C} 26-\mathrm{C} 27-\mathrm{O} 29$ & $-172.3(2)$ \\
\hline $\mathrm{C} 15-\mathrm{C} 16-\mathrm{C} 17-\mathrm{C} 18$ & $-92.4(3)$ & $\mathrm{O} 28-\mathrm{C} 27-\mathrm{O} 29-\mathrm{C} 30$ & $3.0(4)$ \\
\hline $\mathrm{C} 15-\mathrm{C} 16-\mathrm{C} 17-\mathrm{C} 22$ & $86.9(3)$ & $\mathrm{Pt} 1-\mathrm{C} 14-\mathrm{C} 15-\mathrm{C} 16$ & $-104.3(3)$ \\
\hline $\mathrm{C} 16-\mathrm{C} 17-\mathrm{C} 18-\mathrm{C} 19$ & $-180.0(3)$ & $\mathrm{Pt} 1-\mathrm{C} 15-\mathrm{C} 16-\mathrm{C} 17$ & $76.6(3)$ \\
\hline $\mathrm{C} 16-\mathrm{C} 17-\mathrm{C} 22-\mathrm{C} 21$ & $179.4(3)$ & & \\
\hline
\end{tabular}

Hydrogen-bond geometry $\left(\AA,{ }^{\circ}\right)$

$C g 1$ is the centroid of ring N2/C3-C6/C11, $C g 2$ is the centroid of ring $\mathrm{C} 6-\mathrm{C} 11$ and $C g 3$ is the centroid of ring $\mathrm{C} 17-\mathrm{C} 22$.

\begin{tabular}{lllll}
\hline$D-\mathrm{H} \cdots A$ & $D-\mathrm{H}$ & $\mathrm{H} \cdots A$ & $D \cdots A$ & $D-\mathrm{H} \cdots A$ \\
\hline $\mathrm{C} 5-\mathrm{H} 5 \cdots \mathrm{O} 23^{\mathrm{i}}$ & 0.95 & 2.46 & $3.073(4)$ & 122 \\
$\mathrm{C} 16-\mathrm{H} 16 A \cdots \mathrm{O} 12$ & 0.99 & 2.40 & $3.051(4)$ & 123 \\
$\mathrm{C} 14-\mathrm{H} 14 B \cdots C g 1^{\mathrm{ii}}$ & 0.99 & 2.94 & $3.454(4)$ & 114 \\
$\mathrm{C} 24-\mathrm{H} 24 B \cdots C g 2$ & 0.98 & 2.93 & $3.564(4)$ & 124 \\
$\mathrm{C} 30-\mathrm{H} 30 \cdots C g 3^{\text {iii }}$ & 1.00 & 2.96 & $3.827(4)$ & 145 \\
\hline
\end{tabular}

Symmetry codes: (i) $-x,-y+1,-z+1$; (ii) $-x-1,-y,-z+1$; (iii) $-x+1,-y,-z+1$. 
[ $\eta^{2}$-4-Allyl-2-methoxy-1-(propoxycarbonylmethoxy)benzene]chlorido(quinolin-2-carboxylato$\left.\kappa^{2} N, O\right)$ platinum(II) (chi33)

Crystal data

$\left[\mathrm{Pt}\left(\mathrm{C}_{10} \mathrm{H}_{6} \mathrm{O}_{2}\right) \mathrm{Cl}\left(\mathrm{C}_{15} \mathrm{H}_{20} \mathrm{O}_{4}\right)\right]$

$M_{r}=667.01$

Monoclinic, $P 2_{1} / c$

$a=15.6457(13) \AA$

$b=9.7291(4) \AA$

$c=16.6062(8) \AA$

$\beta=111.150(8)^{\circ}$

$V=2357.5(3) \AA^{3}$

$Z=4$

$F(000)=1304$

$D_{\mathrm{x}}=1.879 \mathrm{Mg} \mathrm{m}^{-3}$

Mo $K \alpha$ radiation, $\lambda=0.71073 \AA$

Cell parameters from 6260 reflections

$\theta=3.4-28.0^{\circ}$

$\mu=6.11 \mathrm{~mm}^{-1}$

$T=100 \mathrm{~K}$

Needle, yellow

$0.3 \times 0.15 \times 0.10 \mathrm{~mm}$

\section{Data collection}

Agilent SuperNova Dual Source

diffractometer with an Eos detector

Radiation source: SuperNova (Mo) X-ray

Source

Mirror monochromator

Detector resolution: 15.9631 pixels $\mathrm{mm}^{-1}$

$\omega$ scans

Absorption correction: multi-scan

(CrysAlis PRO; Agilent, 2013)

$T_{\min }=0.522, T_{\max }=1.000$

21714 measured reflections

4030 independent reflections

3348 reflections with $I>2 \sigma(I)$

$R_{\text {int }}=0.066$

$\theta_{\text {max }}=24.7^{\circ}, \theta_{\min }=2.8^{\circ}$

$h=-18 \rightarrow 18$

$k=-11 \rightarrow 11$

$l=-19 \rightarrow 19$

Refinement

Refinement on $F^{2}$

Least-squares matrix: full

$R\left[F^{2}>2 \sigma\left(F^{2}\right)\right]=0.038$

$w R\left(F^{2}\right)=0.086$

$S=1.08$

4030 reflections

316 parameters

0 restraints

Hydrogen site location: inferred from neighbouring sites

$\mathrm{H}$-atom parameters constrained

$w=1 /\left[\sigma^{2}\left(F_{\mathrm{o}}{ }^{2}\right)+(0.0209 P)^{2}+13.4203 P\right]$

where $P=\left(F_{\mathrm{o}}^{2}+2 F_{\mathrm{c}}^{2}\right) / 3$

$(\Delta / \sigma)_{\max }=0.001$

$\Delta \rho_{\max }=2.22 \mathrm{e} \AA^{-3}$

$\Delta \rho_{\min }=-1.13$ e $\AA^{-3}$

Special details

Geometry. All esds (except the esd in the dihedral angle between two 1.s. planes) are estimated using the full covariance matrix. The cell esds are taken into account individually in the estimation of esds in distances, angles and torsion angles; correlations between esds in cell parameters are only used when they are defined by crystal symmetry. An approximate (isotropic) treatment of cell esds is used for estimating esds involving 1.s. planes.

Fractional atomic coordinates and isotropic or equivalent isotropic displacement parameters $\left(\AA^{2}\right)$

\begin{tabular}{llllll}
\hline & $x$ & $y$ & $z$ & $U_{\text {iso }} * / U_{\text {eq }}$ & Occ. $(<1)$ \\
\hline Pt1A & $0.69372(3)$ & $0.90310(4)$ & $0.69364(2)$ & $0.02742(15)$ & $0.9298(13)$ \\
Pt1B & $0.6573(5)$ & $0.9379(6)$ & $0.7023(3)$ & $0.02742(15)$ & $0.0702(13)$ \\
C12A & $0.74945(19)$ & $1.1196(2)$ & $0.69048(14)$ & $0.0519(7)$ & $0.9298(13)$ \\
C12B & $0.710(3)$ & $1.143(4)$ & $0.711(2)$ & $0.0519(7)$ & $0.0702(13)$ \\
N3 & $0.6096(4)$ & $0.8677(6)$ & $0.5632(3)$ & $0.0261(13)$ & \\
C4 & $0.5626(5)$ & $0.7531(7)$ & $0.5569(4)$ & $0.0281(16)$ & \\
C5 & $0.5000(5)$ & $0.7022(8)$ & $0.4798(4)$ & $0.0380(18)$ & \\
H5 & 0.466660 & 0.620352 & 0.479342 & $0.046^{*}$ &
\end{tabular}




\begin{tabular}{|c|c|c|c|c|}
\hline C6 & $0.4873(6)$ & $0.7711(9)$ & $0.4056(5)$ & $0.045(2)$ \\
\hline H6 & 0.444434 & 0.738369 & 0.352463 & $0.054 *$ \\
\hline $\mathrm{C} 7$ & $0.5374(5)$ & $0.8902(8)$ & $0.4075(5)$ & 0.0399 (19) \\
\hline $\mathrm{C} 8$ & $0.5288(6)$ & $0.9618(9)$ & $0.3313(5)$ & $0.049(2)$ \\
\hline H8 & 0.486090 & 0.930261 & 0.277779 & $0.058 *$ \\
\hline C9 & $0.5800(6)$ & $1.0743(10)$ & $0.3325(5)$ & $0.052(2)$ \\
\hline H9 & 0.573686 & 1.121077 & 0.280497 & $0.063 *$ \\
\hline $\mathrm{C} 10$ & $0.6428(6)$ & $1.1212(8)$ & $0.4123(5)$ & $0.048(2)$ \\
\hline H10 & 0.678626 & 1.200557 & 0.413662 & $0.058^{*}$ \\
\hline C11 & $0.6532(6)$ & $1.0544(8)$ & $0.4881(5)$ & $0.0403(19)$ \\
\hline H11 & 0.696339 & 1.087252 & 0.541004 & $0.048^{*}$ \\
\hline $\mathrm{C} 12$ & $0.6004(5)$ & $0.9381(7)$ & $0.4874(4)$ & $0.0302(16)$ \\
\hline $\mathrm{C} 13$ & $0.5797(5)$ & $0.6706(8)$ & $0.6392(4)$ & $0.0326(17)$ \\
\hline O14 & $0.6441(4)$ & $0.7167(5)$ & $0.7062(3)$ & $0.0403(13)$ \\
\hline $\mathrm{O} 15$ & $0.5356(4)$ & $0.5679(5)$ & $0.6383(3)$ & $0.0402(13)$ \\
\hline $\mathrm{C} 16$ & $0.8065(5)$ & $0.8737(8)$ & 0.8114 (4) & $0.0360(18)$ \\
\hline H16A & 0.820957 & 0.779283 & 0.823459 & $0.043 *$ \\
\hline H16B & 0.839552 & 0.927213 & 0.784616 & $0.043^{*}$ \\
\hline C17 & $0.7365(5)$ & $0.9339(8)$ & $0.8331(4)$ & $0.041(2)$ \\
\hline H17 & 0.747581 & 1.031930 & 0.852165 & $0.049^{*}$ \\
\hline H17A & 0.752705 & 1.027924 & 0.858348 & $0.049 *$ \\
\hline C18 & $0.6843(6)$ & $0.8543(9)$ & $0.8744(5)$ & $0.047(2)$ \\
\hline H18A & 0.688324 & 0.755037 & 0.863072 & $0.057 *$ \\
\hline H18B & 0.618940 & 0.881693 & 0.850753 & $0.057^{*}$ \\
\hline C19 & $0.7245(5)$ & $0.8821(9)$ & 0.9717 (4) & $0.041(2)$ \\
\hline $\mathrm{C} 20$ & $0.7935(5)$ & $0.7966(8)$ & $1.0248(4)$ & $0.0373(18)$ \\
\hline $\mathrm{H} 20$ & 0.814797 & 0.721662 & 1.000530 & $0.045^{*}$ \\
\hline $\mathrm{C} 21$ & $0.8313(5)$ & $0.8211(8)$ & $1.1136(4)$ & $0.0323(17)$ \\
\hline $\mathrm{C} 22$ & $0.7985(5)$ & $0.9311(7)$ & $1.1495(4)$ & $0.0304(17)$ \\
\hline $\mathrm{C} 23$ & $0.7315(5)$ & $1.0157(8)$ & $1.0962(4)$ & $0.0358(17)$ \\
\hline $\mathrm{H} 23$ & 0.710572 & 1.092086 & 1.119598 & $0.043 *$ \\
\hline $\mathrm{C} 24$ & $0.6942(5)$ & $0.9891(8)$ & $1.0073(4)$ & $0.0396(19)$ \\
\hline H24 & 0.646899 & 1.046700 & 0.971174 & $0.047^{*}$ \\
\hline $\mathrm{O} 25$ & 0.8981 (3) & $0.7447(5)$ & $1.1711(3)$ & $0.0414(13)$ \\
\hline $\mathrm{C} 26$ & $0.9278(6)$ & $0.6241(9)$ & $1.1385(5)$ & $0.054(2)$ \\
\hline $\mathrm{H} 26 \mathrm{~A}$ & 0.949783 & 0.650355 & 1.092396 & $0.081 *$ \\
\hline H26B & 0.876367 & 0.560041 & 1.115666 & $0.081^{*}$ \\
\hline $\mathrm{H} 26 \mathrm{C}$ & 0.977560 & 0.579745 & 1.185385 & $0.081^{*}$ \\
\hline $\mathrm{O} 27$ & $0.8385(3)$ & $0.9431(5)$ & $1.2376(3)$ & $0.0336(12)$ \\
\hline $\mathrm{C} 28$ & $0.8073(5)$ & $1.0523(7)$ & $1.2750(4)$ & $0.0345(18)$ \\
\hline $\mathrm{H} 28 \mathrm{~A}$ & 0.739919 & 1.046870 & 1.258444 & $0.041 *$ \\
\hline H28B & 0.822518 & 1.141173 & 1.254417 & $0.041 *$ \\
\hline C29 & $0.8532(5)$ & $1.0422(8)$ & $1.3717(4)$ & $0.0305(16)$ \\
\hline $\mathrm{O} 30$ & $0.8787(4)$ & $0.9389(5)$ & $1.4110(3)$ & $0.0367(12)$ \\
\hline O31 & $0.8578(3)$ & $1.1679(5)$ & $1.4060(3)$ & $0.0366(12)$ \\
\hline C32 & $0.8972(5)$ & $1.1747(8)$ & $1.4997(4)$ & 0.0414 (19) \\
\hline $\mathrm{H} 32 \mathrm{~A}$ & 0.952958 & 1.116983 & 1.521270 & $0.050 *$ \\
\hline H32B & 0.852620 & 1.139311 & 1.524470 & $0.050^{*}$ \\
\hline
\end{tabular}

$0.9298(13)$

0.0702 (13) 


\begin{tabular}{lllll}
$\mathrm{C} 33$ & $0.9208(6)$ & $1.3209(8)$ & $1.5269(5)$ & $0.050(2)$ \\
$\mathrm{H} 33 \mathrm{~A}$ & 0.866320 & 1.380139 & 1.500989 & $0.060^{*}$ \\
$\mathrm{H} 33 \mathrm{~B}$ & 0.969642 & 1.353675 & 1.506787 & $0.060^{*}$ \\
$\mathrm{C} 34$ & $0.9536(7)$ & $1.3289(11)$ & $1.6247(5)$ & $0.066(3)$ \\
$\mathrm{H} 34 \mathrm{~A}$ & 0.972162 & 1.423355 & 1.643341 & $0.099^{*}$ \\
$\mathrm{H} 34 \mathrm{~B}$ & 1.005973 & 1.267105 & 1.649891 & $0.099^{*}$ \\
$\mathrm{H} 34 \mathrm{C}$ & 0.903806 & 1.301305 & 1.643904 & $0.099^{*}$ \\
\hline
\end{tabular}

Atomic displacement parameters $\left(\AA^{2}\right)$

\begin{tabular}{|c|c|c|c|c|c|c|}
\hline & $U^{11}$ & $U^{22}$ & $U^{33}$ & $U^{12}$ & $U^{13}$ & $U^{23}$ \\
\hline Pt1A & $0.0359(3)$ & $0.0302(2)$ & $0.01614(15)$ & $0.00021(17)$ & 0.00946 (13) & $0.00123(13)$ \\
\hline Pt1B & 0.0359 (3) & $0.0302(2)$ & $0.01614(15)$ & $0.00021(17)$ & 0.00946 (13) & $0.00123(13)$ \\
\hline $\mathrm{Cl} 2 \mathrm{~A}$ & 0.0799 (19) & $0.0368(13)$ & $0.0309(12)$ & $-0.0187(12)$ & $0.0103(11)$ & $0.0034(9)$ \\
\hline $\mathrm{Cl} 2 \mathrm{~B}$ & 0.0799 (19) & $0.0368(13)$ & $0.0309(12)$ & $-0.0187(12)$ & $0.0103(11)$ & $0.0034(9)$ \\
\hline N3 & $0.030(3)$ & $0.034(4)$ & $0.017(3)$ & $0.006(3)$ & $0.012(2)$ & $0.001(2)$ \\
\hline $\mathrm{C} 4$ & $0.031(4)$ & $0.036(4)$ & $0.020(3)$ & $0.004(3)$ & $0.011(3)$ & $0.001(3)$ \\
\hline $\mathrm{C} 5$ & 0.039 (4) & $0.053(5)$ & $0.021(4)$ & -0.007 (4) & $0.010(3)$ & -0.009 (3) \\
\hline C6 & $0.057(5)$ & $0.055(6)$ & $0.022(4)$ & $0.008(4)$ & $0.012(4)$ & $-0.004(4)$ \\
\hline $\mathrm{C} 7$ & $0.051(5)$ & $0.052(5)$ & $0.025(4)$ & $0.018(4)$ & $0.023(4)$ & $0.002(3)$ \\
\hline $\mathrm{C} 8$ & $0.072(6)$ & $0.058(6)$ & $0.020(4)$ & $0.015(5)$ & $0.022(4)$ & 0.009 (4) \\
\hline $\mathrm{C} 9$ & $0.072(6)$ & $0.067(6)$ & $0.028(4)$ & $0.031(5)$ & $0.030(4)$ & $0.016(4)$ \\
\hline $\mathrm{C} 10$ & $0.061(6)$ & $0.042(5)$ & $0.053(5)$ & $0.010(4)$ & $0.033(5)$ & $0.019(4)$ \\
\hline C11 & $0.054(5)$ & $0.043(5)$ & $0.028(4)$ & $0.010(4)$ & $0.020(4)$ & 0.007 (3) \\
\hline $\mathrm{C} 12$ & $0.036(4)$ & $0.038(4)$ & $0.021(4)$ & 0.010 & $0.015(3)$ & $0.006(3)$ \\
\hline $\mathrm{C} 13$ & $0.037(4)$ & $0.041(5)$ & $0.022(4)$ & 0.000 (4) & $0.013(3)$ & $0.002(3)$ \\
\hline $\mathrm{O} 14$ & $0.064(4)$ & $0.041(3)$ & $0.013(2)$ & $-0.013(3)$ & $0.010(2)$ & $0.004(2)$ \\
\hline O15 & $0.051(3)$ & 0.048 & 0.025 & $-0.022(3)$ & $0.018(2)$ & $-0.005(2)$ \\
\hline $\mathrm{C} 16$ & $0.043(4)$ & $0.041(5)$ & $0.022(4)$ & $0.004(4)$ & 0.009 (3) & $0.004(3)$ \\
\hline $\mathrm{C} 17$ & $0.056(5)$ & $0.049(5)$ & 0.010 & $0.003(4)$ & 0.003 & $-0.002(3)$ \\
\hline $\mathrm{C} 18$ & $0.050(5)$ & $0.062(6)$ & $0.030(4)$ & $-0.013(4)$ & $0.016(4)$ & $-0.008(4)$ \\
\hline C19 & $0.047(5)$ & $0.059(6)$ & 0.019 (4) & $-0.013(4)$ & $0.015(4)$ & $0.002(4)$ \\
\hline $\mathrm{C} 20$ & $0.048(5)$ & $0.042(5)$ & $0.031(4)$ & $-0.013(4)$ & $0.026(4)$ & $-0.013(3)$ \\
\hline $\mathrm{C} 21$ & $0.034(4)$ & $0.038(4)$ & $0.029(4)$ & $-0.005(3)$ & $0.015(3)$ & $-0.003(3)$ \\
\hline $\mathrm{C} 22$ & $0.037(4)$ & $0.037(4)$ & $0.019(3)$ & $-0.012(3)$ & 0.013 & $0.000(3)$ \\
\hline $\mathrm{C} 23$ & $0.040(4)$ & $0.042(5)$ & $0.026(4)$ & -0.001 & $0.013(3)$ & 0.003 \\
\hline $\mathrm{C} 24$ & $0.041(5)$ & $0.055(5)$ & $0.020(4)$ & -0.005 & 0.009 (3) & -0.001 \\
\hline $\mathrm{O} 25$ & 0.049 (3) & $0.048(3)$ & 0.030 & $0.005(3)$ & $0.017(3)$ & $-0.009(2)$ \\
\hline $\mathrm{C} 26$ & $0.066(6)$ & $0.054(6)$ & $0.046(5)$ & $0.011(5)$ & $0.027(5)$ & -0.009 \\
\hline $\mathrm{O} 27$ & $0.041(3)$ & $0.036(3)$ & $0.022(2)$ & $0.001(2)$ & $0.009(2)$ & $-0.005(2)$ \\
\hline $\mathrm{C} 28$ & $0.052(5)$ & $0.033(4)$ & $0.016(3)$ & $0.000(3)$ & 0.009 (3) & -0.001 \\
\hline $\mathrm{C} 29$ & $0.035(4)$ & $0.030(4)$ & $0.031(4)$ & $-0.002(3)$ & $0.017(3)$ & -0.003 \\
\hline $\mathrm{O} 30$ & $0.053(3)$ & $0.032(3)$ & $0.023(3)$ & $0.000(2)$ & $0.011(2)$ & $-0.001(2)$ \\
\hline $\mathrm{O} 31$ & $0.056(3)$ & 0.030 & $0.020(2)$ & $0.003(2)$ & $0.010(2)$ & $-0.003(2)$ \\
\hline $\mathrm{C} 32$ & $0.048(5)$ & $0.053(5)$ & $0.022(4)$ & 0.003 & $0.012(4)$ & $-0.004(3)$ \\
\hline $\mathrm{C} 33$ & $0.067(6)$ & $0.045(5)$ & $0.032(4)$ & $0.012(4)$ & $0.008(4)$ & -0.018 \\
\hline C 34 & $0.067(7)$ & $0.085(7)$ & $0.039(5)$ & $0.011(5)$ & $0.011(5)$ & $-0.023(5)$ \\
\hline
\end{tabular}


Geometric parameters $\left(A,{ }^{o}\right)$

\begin{tabular}{|c|c|c|c|}
\hline $\mathrm{PT} 1 \mathrm{Aa}-\mathrm{Cl} 2 \mathrm{~A}$ & $2.287(2)$ & $\mathrm{C} 17-\mathrm{C} 18$ & $1.464(11)$ \\
\hline $\mathrm{PT} 1 \mathrm{Bb}-\mathrm{Cl} 2 \mathrm{~B}$ & $2.14(3)$ & $\mathrm{C} 18-\mathrm{H} 18 \mathrm{~A}$ & 0.9900 \\
\hline $\mathrm{PT} 1 \mathrm{Aa}-\mathrm{N} 3$ & $2.118(5)$ & $\mathrm{C} 18-\mathrm{H} 18 \mathrm{~B}$ & 0.9900 \\
\hline $\mathrm{PT} 1 \mathrm{Bb}-\mathrm{N} 3$ & $2.262(7)$ & $\mathrm{C} 18-\mathrm{C} 19$ & $1.533(10)$ \\
\hline PT1Aa-O14 & $2.013(5)$ & $\mathrm{C} 19-\mathrm{C} 20$ & $1.396(11)$ \\
\hline $\mathrm{PT} 1 \mathrm{Bb}-\mathrm{O} 14$ & $2.166(7)$ & $\mathrm{C} 19-\mathrm{C} 24$ & $1.363(11)$ \\
\hline $\mathrm{PT} 1 \mathrm{Bb}-\mathrm{C} 16$ & $2.464(9)$ & $\mathrm{C} 20-\mathrm{H} 20$ & 0.9500 \\
\hline PT1Aa-C16 & $2.128(7)$ & $\mathrm{C} 20-\mathrm{C} 21$ & $1.397(9)$ \\
\hline PT1Aa-C17 & $2.186(6)$ & $\mathrm{C} 21-\mathrm{C} 22$ & $1.409(10)$ \\
\hline $\mathrm{PT} 1 \mathrm{Bb}-\mathrm{C} 17$ & $2.077(8)$ & $\mathrm{C} 21-\mathrm{O} 25$ & $1.355(8)$ \\
\hline $\mathrm{N} 3-\mathrm{C} 4$ & $1.320(9)$ & $\mathrm{C} 22-\mathrm{C} 23$ & $1.374(10)$ \\
\hline N3-C12 & $1.393(8)$ & $\mathrm{C} 22-\mathrm{O} 27$ & $1.373(7)$ \\
\hline $\mathrm{C} 4-\mathrm{C} 5$ & $1.392(9)$ & $\mathrm{C} 23-\mathrm{H} 23$ & 0.9500 \\
\hline $\mathrm{C} 4-\mathrm{C} 13$ & $1.522(9)$ & $\mathrm{C} 23-\mathrm{C} 24$ & $1.402(9)$ \\
\hline $\mathrm{C} 5-\mathrm{H} 5$ & 0.9500 & $\mathrm{C} 24-\mathrm{H} 24$ & 0.9500 \\
\hline $\mathrm{C} 5-\mathrm{C} 6$ & $1.353(10)$ & $\mathrm{O} 25-\mathrm{C} 26$ & $1.437(9)$ \\
\hline $\mathrm{C} 6-\mathrm{H} 6$ & 0.9500 & $\mathrm{C} 26-\mathrm{H} 26 \mathrm{~A}$ & 0.9800 \\
\hline $\mathrm{C} 6-\mathrm{C} 7$ & $1.393(11)$ & $\mathrm{C} 26-\mathrm{H} 26 \mathrm{~B}$ & 0.9800 \\
\hline $\mathrm{C} 7-\mathrm{C} 8$ & $1.408(10)$ & $\mathrm{C} 26-\mathrm{H} 26 \mathrm{C}$ & 0.9800 \\
\hline $\mathrm{C} 7-\mathrm{C} 12$ & $1.416(10)$ & $\mathrm{O} 27-\mathrm{C} 28$ & $1.405(8)$ \\
\hline $\mathrm{C} 8-\mathrm{H} 8$ & 0.9500 & $\mathrm{C} 28-\mathrm{H} 28 \mathrm{~A}$ & 0.9900 \\
\hline $\mathrm{C} 8-\mathrm{C} 9$ & $1.352(12)$ & $\mathrm{C} 28-\mathrm{H} 28 \mathrm{~B}$ & 0.9900 \\
\hline $\mathrm{C} 9-\mathrm{H} 9$ & 0.9500 & $\mathrm{C} 28-\mathrm{C} 29$ & $1.508(9)$ \\
\hline $\mathrm{C} 9-\mathrm{C} 10$ & $1.411(12)$ & $\mathrm{C} 29-\mathrm{O} 30$ & $1.186(8)$ \\
\hline $\mathrm{C} 10-\mathrm{H} 10$ & 0.9500 & $\mathrm{C} 29-\mathrm{O} 31$ & $1.340(8)$ \\
\hline $\mathrm{C} 10-\mathrm{C} 11$ & $1.372(10)$ & $\mathrm{O} 31-\mathrm{C} 32$ & $1.453(8)$ \\
\hline C11-H11 & 0.9500 & $\mathrm{C} 32-\mathrm{H} 32 \mathrm{~A}$ & 0.9900 \\
\hline $\mathrm{C} 11-\mathrm{C} 12$ & $1.399(10)$ & $\mathrm{C} 32-\mathrm{H} 32 \mathrm{~B}$ & 0.9900 \\
\hline $\mathrm{C} 13-\mathrm{O} 14$ & $1.283(8)$ & $\mathrm{C} 32-\mathrm{C} 33$ & $1.498(11)$ \\
\hline $\mathrm{C} 13-\mathrm{O} 15$ & $1.212(8)$ & $\mathrm{C} 33-\mathrm{H} 33 \mathrm{~A}$ & 0.9900 \\
\hline C16-H16A & 0.9500 & $\mathrm{C} 33-\mathrm{H} 33 \mathrm{~B}$ & 0.9900 \\
\hline C16-H16B & 0.9500 & $\mathrm{C} 33-\mathrm{C} 34$ & $1.518(10)$ \\
\hline $\mathrm{C} 16-\mathrm{C} 17$ & $1.399(10)$ & $\mathrm{C} 34-\mathrm{H} 34 \mathrm{~A}$ & 0.9800 \\
\hline $\mathrm{C} 17-\mathrm{H} 17$ & 1.0000 & $\mathrm{C} 34-\mathrm{H} 34 \mathrm{~B}$ & 0.9800 \\
\hline C17-H17A & 1.0000 & $\mathrm{C} 34-\mathrm{H} 34 \mathrm{C}$ & 0.9800 \\
\hline $\mathrm{CL} 2 \mathrm{Bb}-\mathrm{PT} 1 \mathrm{Bb}-\mathrm{N} 3$ & $108.9(9)$ & $\mathrm{C} 17-\mathrm{PT} 1 \mathrm{Bb}-\mathrm{N} 3$ & $156.2(5)$ \\
\hline $\mathrm{CL} 2 \mathrm{Bb}-\mathrm{PT} 1 \mathrm{Bb}-\mathrm{O} 14$ & $163.9(12)$ & $\mathrm{C} 17-\mathrm{PT} 1 \mathrm{Bb}-\mathrm{O} 14$ & $88.7(3)$ \\
\hline $\mathrm{CL} 2 \mathrm{Bb}-\mathrm{PT} 1 \mathrm{Bb}-\mathrm{C} 16$ & $87.0(10)$ & $\mathrm{C} 17-\mathrm{PT} 1 \mathrm{Bb}-\mathrm{C} 16$ & $34.6(3)$ \\
\hline PT1Aa-C16-H16A & 112.3 & $\mathrm{C} 18-\mathrm{C} 17-\mathrm{Pt} 1 \mathrm{~A}$ & $114.5(5)$ \\
\hline PT1Aa-C16-H16B & 84.7 & $\mathrm{C} 18-\mathrm{C} 17-\mathrm{Pt} 1 \mathrm{~B}$ & $106.1(5)$ \\
\hline $\mathrm{H} 16 \mathrm{Aa}-\mathrm{C} 16-\mathrm{H} 16 \mathrm{~B}$ & 120.0 & $\mathrm{C} 18-\mathrm{C} 17-\mathrm{H} 17$ & 114.7 \\
\hline PT1Aa-C17—H17 & 114.7 & $\mathrm{C} 18-\mathrm{C} 17-\mathrm{H} 17 \mathrm{~A}$ & 112.8 \\
\hline $\mathrm{PT} 1 \mathrm{Bb}-\mathrm{C} 17-\mathrm{H} 17 \mathrm{~A}$ & 112.8 & $\mathrm{C} 17-\mathrm{C} 18-\mathrm{H} 18 \mathrm{~A}$ & 110.0 \\
\hline $\mathrm{N} 3-\mathrm{PT} 1 \mathrm{Aa}-\mathrm{Cl} 2 \mathrm{~A}$ & $103.13(16)$ & $\mathrm{C} 17-\mathrm{C} 18-\mathrm{H} 18 \mathrm{~B}$ & 110.0 \\
\hline $\mathrm{N} 3-\mathrm{PT} 1 \mathrm{Bb}-\mathrm{C} 16$ & $123.4(4)$ & $\mathrm{C} 17-\mathrm{C} 18-\mathrm{C} 19$ & $108.3(6)$ \\
\hline
\end{tabular}




\begin{tabular}{|c|c|c|c|}
\hline $\mathrm{N} 3-\mathrm{PT} 1 \mathrm{Aa}-\mathrm{C} 16$ & $157.1(2)$ & $\mathrm{H} 18 \mathrm{~A}-\mathrm{C} 18-\mathrm{H} 18 \mathrm{~B}$ & 108.4 \\
\hline N3-PT1Aa-C17 & $161.0(3)$ & $\mathrm{C} 19-\mathrm{C} 18-\mathrm{H} 18 \mathrm{~A}$ & 110.0 \\
\hline $\mathrm{C} 4-\mathrm{N} 3-\mathrm{Pt} 1 \mathrm{~A}$ & $109.9(4)$ & $\mathrm{C} 19-\mathrm{C} 18-\mathrm{H} 18 \mathrm{~B}$ & 110.0 \\
\hline $\mathrm{C} 4-\mathrm{N} 3-\mathrm{Pt} 1 \mathrm{~B}$ & $107.7(4)$ & $\mathrm{C} 20-\mathrm{C} 19-\mathrm{C} 18$ & $119.4(7)$ \\
\hline $\mathrm{C} 4-\mathrm{N} 3-\mathrm{C} 12$ & $118.1(6)$ & $\mathrm{C} 24-\mathrm{C} 19-\mathrm{C} 18$ & $121.2(7)$ \\
\hline $\mathrm{C} 12-\mathrm{N} 3-\mathrm{Pt} 1 \mathrm{~A}$ & $131.9(5)$ & $\mathrm{C} 24-\mathrm{C} 19-\mathrm{C} 20$ & $119.5(7)$ \\
\hline $\mathrm{C} 12-\mathrm{N} 3-\mathrm{Pt} 1 \mathrm{~B}$ & $131.5(5)$ & $\mathrm{C} 19-\mathrm{C} 20-\mathrm{H} 20$ & 120.0 \\
\hline $\mathrm{N} 3-\mathrm{C} 4-\mathrm{C} 5$ & $124.0(6)$ & $\mathrm{C} 19-\mathrm{C} 20-\mathrm{C} 21$ & $120.1(7)$ \\
\hline $\mathrm{N} 3-\mathrm{C} 4-\mathrm{C} 13$ & $117.5(6)$ & $\mathrm{C} 21-\mathrm{C} 20-\mathrm{H} 20$ & 120.0 \\
\hline $\mathrm{C} 5-\mathrm{C} 4-\mathrm{C} 13$ & $118.4(7)$ & $\mathrm{C} 20-\mathrm{C} 21-\mathrm{C} 22$ & $119.7(7)$ \\
\hline $\mathrm{C} 4-\mathrm{C} 5-\mathrm{H} 5$ & 120.5 & $\mathrm{O} 25-\mathrm{C} 21-\mathrm{C} 20$ & $125.1(7)$ \\
\hline $\mathrm{C} 6-\mathrm{C} 5-\mathrm{C} 4$ & $119.0(8)$ & $\mathrm{O} 25-\mathrm{C} 21-\mathrm{C} 22$ & $115.2(6)$ \\
\hline $\mathrm{C} 6-\mathrm{C} 5-\mathrm{H} 5$ & 120.5 & $\mathrm{C} 23-\mathrm{C} 22-\mathrm{C} 21$ & $119.5(6)$ \\
\hline $\mathrm{C} 5-\mathrm{C} 6-\mathrm{H} 6$ & 120.2 & $\mathrm{O} 27-\mathrm{C} 22-\mathrm{C} 21$ & $114.8(6)$ \\
\hline $\mathrm{C} 5-\mathrm{C} 6-\mathrm{C} 7$ & $119.6(7)$ & $\mathrm{O} 27-\mathrm{C} 22-\mathrm{C} 23$ & $125.7(7)$ \\
\hline $\mathrm{C} 7-\mathrm{C} 6-\mathrm{H} 6$ & 120.2 & $\mathrm{C} 22-\mathrm{C} 23-\mathrm{H} 23$ & 120.1 \\
\hline $\mathrm{C} 6-\mathrm{C} 7-\mathrm{C} 8$ & $121.4(8)$ & $\mathrm{C} 22-\mathrm{C} 23-\mathrm{C} 24$ & $119.9(7)$ \\
\hline $\mathrm{C} 6-\mathrm{C} 7-\mathrm{C} 12$ & $119.4(7)$ & $\mathrm{C} 24-\mathrm{C} 23-\mathrm{H} 23$ & 120.1 \\
\hline $\mathrm{C} 8-\mathrm{C} 7-\mathrm{C} 12$ & $119.2(8)$ & $\mathrm{C} 19-\mathrm{C} 24-\mathrm{C} 23$ & $121.3(7)$ \\
\hline $\mathrm{C} 7-\mathrm{C} 8-\mathrm{H} 8$ & 119.2 & $\mathrm{C} 19-\mathrm{C} 24-\mathrm{H} 24$ & 119.3 \\
\hline $\mathrm{C} 9-\mathrm{C} 8-\mathrm{C} 7$ & $121.5(8)$ & $\mathrm{C} 23-\mathrm{C} 24-\mathrm{H} 24$ & 119.3 \\
\hline $\mathrm{C} 9-\mathrm{C} 8-\mathrm{H} 8$ & 119.2 & $\mathrm{C} 21-\mathrm{O} 25-\mathrm{C} 26$ & $117.1(6)$ \\
\hline $\mathrm{C} 8-\mathrm{C} 9-\mathrm{H} 9$ & 120.5 & $\mathrm{O} 25-\mathrm{C} 26-\mathrm{H} 26 \mathrm{~A}$ & 109.5 \\
\hline $\mathrm{C} 8-\mathrm{C} 9-\mathrm{C} 10$ & $118.9(7)$ & $\mathrm{O} 25-\mathrm{C} 26-\mathrm{H} 26 \mathrm{~B}$ & 109.5 \\
\hline $\mathrm{C} 10-\mathrm{C} 9-\mathrm{H} 9$ & 120.5 & $\mathrm{O} 25-\mathrm{C} 26-\mathrm{H} 26 \mathrm{C}$ & 109.5 \\
\hline $\mathrm{C} 9-\mathrm{C} 10-\mathrm{H} 10$ & 119.3 & $\mathrm{H} 26 \mathrm{~A}-\mathrm{C} 26-\mathrm{H} 26 \mathrm{~B}$ & 109.5 \\
\hline $\mathrm{C} 11-\mathrm{C} 10-\mathrm{C} 9$ & $121.3(8)$ & $\mathrm{H} 26 \mathrm{~A}-\mathrm{C} 26-\mathrm{H} 26 \mathrm{C}$ & 109.5 \\
\hline $\mathrm{C} 11-\mathrm{C} 10-\mathrm{H} 10$ & 119.3 & $\mathrm{H} 26 \mathrm{~B}-\mathrm{C} 26-\mathrm{H} 26 \mathrm{C}$ & 109.5 \\
\hline $\mathrm{C} 10-\mathrm{C} 11-\mathrm{H} 11$ & 119.9 & $\mathrm{C} 22-\mathrm{O} 27-\mathrm{C} 28$ & $115.9(5)$ \\
\hline $\mathrm{C} 10-\mathrm{C} 11-\mathrm{C} 12$ & $120.1(8)$ & $\mathrm{O} 27-\mathrm{C} 28-\mathrm{H} 28 \mathrm{~A}$ & 110.0 \\
\hline $\mathrm{C} 12-\mathrm{C} 11-\mathrm{H} 11$ & 119.9 & $\mathrm{O} 27-\mathrm{C} 28-\mathrm{H} 28 \mathrm{~B}$ & 110.0 \\
\hline $\mathrm{N} 3-\mathrm{C} 12-\mathrm{C} 7$ & $119.6(7)$ & $\mathrm{O} 27-\mathrm{C} 28-\mathrm{C} 29$ & $108.3(6)$ \\
\hline $\mathrm{N} 3-\mathrm{C} 12-\mathrm{C} 11$ & $121.5(6)$ & $\mathrm{H} 28 \mathrm{~A}-\mathrm{C} 28-\mathrm{H} 28 \mathrm{~B}$ & 108.4 \\
\hline $\mathrm{C} 11-\mathrm{C} 12-\mathrm{C} 7$ & $118.8(6)$ & $\mathrm{C} 29-\mathrm{C} 28-\mathrm{H} 28 \mathrm{~A}$ & 110.0 \\
\hline $\mathrm{O} 14-\mathrm{C} 13-\mathrm{C} 4$ & $115.1(6)$ & $\mathrm{C} 29-\mathrm{C} 28-\mathrm{H} 28 \mathrm{~B}$ & 110.0 \\
\hline $\mathrm{O} 15-\mathrm{C} 13-\mathrm{C} 4$ & $120.6(6)$ & $\mathrm{O} 30-\mathrm{C} 29-\mathrm{C} 28$ & $125.3(7)$ \\
\hline $\mathrm{O} 15-\mathrm{C} 13-\mathrm{O} 14$ & $124.3(6)$ & $\mathrm{O} 30-\mathrm{C} 29-\mathrm{O} 31$ & $125.7(6)$ \\
\hline $\mathrm{C} 13-\mathrm{O} 14-\mathrm{Pt} 1 \mathrm{~A}$ & $115.8(4)$ & $\mathrm{O} 31-\mathrm{C} 29-\mathrm{C} 28$ & $109.0(6)$ \\
\hline $\mathrm{C} 13-\mathrm{O} 14-\mathrm{Pt} 1 \mathrm{~B}$ & $112.0(5)$ & $\mathrm{C} 29-\mathrm{O} 31-\mathrm{C} 32$ & $115.7(6)$ \\
\hline $\mathrm{C} 17-\mathrm{C} 16-\mathrm{Pt} 1 \mathrm{~A}$ & $73.4(4)$ & $\mathrm{O} 31-\mathrm{C} 32-\mathrm{H} 32 \mathrm{~A}$ & 109.8 \\
\hline $\mathrm{O} 14-\mathrm{PT} 1 \mathrm{Aa}-\mathrm{Cl} 2 \mathrm{~A}$ & $175.13(14)$ & $\mathrm{O} 31-\mathrm{C} 32-\mathrm{H} 32 \mathrm{~B}$ & 109.8 \\
\hline $\mathrm{O} 14-\mathrm{PT} 1 \mathrm{Aa}-\mathrm{N} 3$ & $80.8(2)$ & $\mathrm{O} 31-\mathrm{C} 32-\mathrm{C} 33$ & $109.2(6)$ \\
\hline $\mathrm{O} 14-\mathrm{PT} 1 \mathrm{Bb}-\mathrm{N} 3$ & $74.4(2)$ & $\mathrm{H} 32 \mathrm{~A}-\mathrm{C} 32-\mathrm{H} 32 \mathrm{~B}$ & 108.3 \\
\hline $\mathrm{O} 14-\mathrm{PT} 1 \mathrm{Aa}-\mathrm{C} 16$ & $90.4(2)$ & $\mathrm{C} 33-\mathrm{C} 32-\mathrm{H} 32 \mathrm{~A}$ & 109.8 \\
\hline $\mathrm{O} 14-\mathrm{PT} 1 \mathrm{Bb}-\mathrm{C} 16$ & $78.5(3)$ & $\mathrm{C} 33-\mathrm{C} 32-\mathrm{H} 32 \mathrm{~B}$ & 109.8 \\
\hline $\mathrm{O} 14-\mathrm{PT} 1 \mathrm{Aa}-\mathrm{C} 17$ & $89.8(3)$ & $\mathrm{C} 32-\mathrm{C} 33-\mathrm{H} 33 \mathrm{~A}$ & 109.9 \\
\hline $\mathrm{C} 16-\mathrm{PT} 1 \mathrm{Aa}-\mathrm{C} 12 \mathrm{~A}$ & $87.0(2)$ & $\mathrm{C} 32-\mathrm{C} 33-\mathrm{H} 33 \mathrm{~B}$ & 109.9 \\
\hline C16-PT1Aa-C17 & $37.8(3)$ & $\mathrm{C} 32-\mathrm{C} 33-\mathrm{C} 34$ & $108.8(7)$ \\
\hline
\end{tabular}




$\begin{array}{ll}\text { C17-C16-Pt1B } & 57.4(4) \\ \text { C17-C16-H16A } & 120.0 \\ \text { C17-C16-H16B } & 120.0 \\ \text { C16-C17-Pt1A } & 68.8(4) \\ \text { C16-C17-Pt1B } & 88.0(5) \\ \text { C16-C17-H17 } & 114.7 \\ \text { C16-C17-H17A } & 112.8 \\ \text { C16-C17-C18 } & 121.3(7) \\ \text { C17-PT1Aa-C12A } & 85.7(2) \\ \text { C17-PT1Bb-C12B } & 83.1(9) \\ & \\ \text { PT1Aa-N3-C4-C5 } & 179.0(6) \\ \text { PT1Bb-N3-C4-C5 } & 159.5(6) \\ \text { PT1Aa-N3-C4-C13 } & -2.3(7) \\ \text { PT1Bb-N3-C4-C13 } & -21.8(7) \\ \text { PT1Bb-N3-C12-C7 } & -155.0(6) \\ \text { PT1Aa-N3-C12-C7 } & -180.0(5) \\ \text { PT1Bb-N3-C12-C11 } & 26.1(10) \\ \text { PT1Aa-N3-C12-C11 } & 1.2(10) \\ \text { N3-C4-C5-C6 } & 1.8(11) \\ \text { N3-C4-C13-O14 } & -4.9(9) \\ \text { N3-C4-C13-O15 } & 176.6(6) \\ \text { C4-N3-C12-C7 } & 3.8(9) \\ \text { C4-N3-C12-C11 } & -175.0(6) \\ \text { C4-C5-C6-C7 } & 0.6(11) \\ \text { C4-C13-O14-PT1Bb } & 30.8(8) \\ \text { C4-C13-O14-PT1Aa } & 10.0(8) \\ \text { C5-C4-C13-O14 } & 173.9(6) \\ \text { C5-C4-C13-O15 } & -4.6(10) \\ \text { C5-C6-C7-C8 } & 177.5(7) \\ \text { C5-C6-C7-C12 } & -0.6(11) \\ \text { C6-C7-C8-C9 } & -177.4(8) \\ \text { C6-C7-C12-N3 } & -1.7(10) \\ \text { C6-C7-C12-C11 } & 177.3(7) \\ \text { C7-C8-C9-C10 } & -0.5(12) \\ \text { C8-C7-C12-N3 } & -179.8(6) \\ \text { C8-C7-C12-C11 } & -0.9(10) \\ \text { C8-C9-C10-C11 } & 0.4(12) \\ \text { C9-C10-C11-C12 } & -0.6(12) \\ \text { C10-C11-C12-N3 } & 179.7(7) \\ \text { C10-C11-C12-C7 } & 0.8(11) \\ \text { C12-N3-C4-C5 } & -4.0(10) \\ \text { C12-N3-C4-C13 } & 174.7(6) \\ \text { C12-C7-C8-C9 } & 0.7(12) \\ \text { C13-C4-C5-C6 } & -176.9(7) \\ & \end{array}$

$\begin{array}{ll}\text { H33A-C33-H33B } & 108.3 \\ \text { C34-C33-H33A } & 109.9 \\ \text { C34-C33-H33B } & 109.9 \\ \text { C33-C34-H34A } & 109.5 \\ \text { C33-C34-H34B } & 109.5 \\ \text { C33-C34-H34C } & 109.5 \\ \text { H34A-C34-H34B } & 109.5 \\ \text { H34A-C34-H34C } & 109.5 \\ \text { H34B-C34-H34C } & 109.5\end{array}$

$\mathrm{O} 15-\mathrm{C} 13-\mathrm{O} 14-\mathrm{PT} 1 \mathrm{Bb}$

$-150.9(7)$

$-171.7(6)$

$106.5(7)$

$107.7(7)$

$177.7(5)$

$-163.8(6)$

$98.5(8)$

$-91.5(9)$

$88.3(9)$

$179.6(6)$

$-179.3(7)$

$1.0(10)$

$179.7(7)$

0.5 (11)

$-2.1(10)$

$178.1(6)$

$-4.3(10)$

$2.3(11)$

$179.7(6)$

$174.5(6)$

$-1.6(11)$

$175.6(6)$

$-0.1(10)$

$-0.2(11)$

$179.1(6)$

$-0.7(9)$

$-177.9(6)$

$-28.6(10)$

$153.3(6)$

$177.5(6)$

$164.9(7)$

$-0.5(10)$

174.8 (7) 
supporting information

Hydrogen-bond geometry $\left(A,{ }^{\circ}\right)$

\begin{tabular}{lllll}
\hline$D-\mathrm{H} \cdots A$ & $D-\mathrm{H}$ & $\mathrm{H} \cdots A$ & $D \cdots A$ & $D-\mathrm{H} \cdots A$ \\
\hline $\mathrm{C} 11-\mathrm{H} 11 \cdots \mathrm{C} 2 A$ & 0.95 & 2.34 & $3.211(8)$ & 153 \\
$\mathrm{C} 11-\mathrm{H} 11 \cdots \mathrm{Cl} 2 B$ & 0.95 & 2.81 & $3.59(3)$ & 140 \\
$\mathrm{C} 16-\mathrm{H} 16 A \cdots \mathrm{O} 30^{\mathrm{i}}$ & 0.95 & 2.55 & $3.452(9)$ & 159 \\
$\mathrm{C} 20-\mathrm{H} 20 \cdots \mathrm{O} 30^{\mathrm{i}}$ & 0.95 & 2.59 & $3.524(9)$ & 167 \\
$\mathrm{C} 28-\mathrm{H} 28 B \cdots \mathrm{C} 2 A^{\mathrm{ii}}$ & 0.99 & 2.64 & $3.473(7)$ & 142 \\
$\mathrm{C} 32-\mathrm{H} 32 A \cdots \mathrm{O} 30^{\text {iii }}$ & 0.99 & 2.52 & $3.459(10)$ & 158
\end{tabular}

Symmetry codes: (i) $x,-y+3 / 2, z-1 / 2$; (ii) $x,-y+5 / 2, z+1 / 2$; (iii) $-x+2,-y+2,-z+3$. 